\title{
Guilty Associations: Joint Criminal Enterprise, Command Responsibility, and the Development of International Criminal Law
}

\author{
Allison Marston Danner $†$ and Jenny S. Martinez $\ddagger$
}

\section{TABLE OF CONTENTS}

Introduction

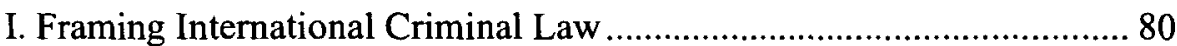

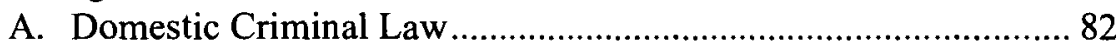

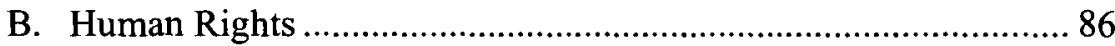

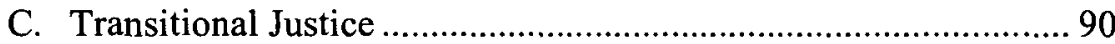

Il. International Criminal Law at the Crossroads:

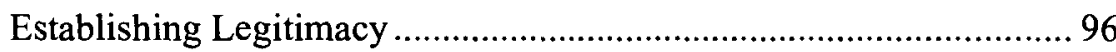

Ill. Joint Criminal Enterprise and Command Responsibility:

Doctrine and History

A. The Development of Joint Criminal Enterprise ......................... 103

1. The Tadić Decision: The ICTY Embraces JCE .................... 104

2. JCE, Conspiracy, and Organizational Liability in

World War II-era Prosecutions.............................................. 110

a. JCE/Common Plan/Common Design Liability............... 110

b. Criminal Organizations .................................................. 112

c. Conspiracy ................................................................ 114

Copyright $\bigcirc 2005$ California Law Review, Inc. Califomia Law Review, Inc. (CLR) is a Califomia nonprofit corporation. CLR and the authors are solely responsible for the content of their publications.

$\dagger \quad$ Associate Professor, Vanderbilt University Law School.

$\ddagger$ Assistant Professor, Stanford Law School. The authors would like to thank the members of the ICTY judiciary and the staff of the Office of the Prosecutor who agreed to be interviewed in connection with this Article. We also gratefully acknowledge the assistance of Rebecca Brown, Mariano-Florentino Cuéllar, Mark Drumbl, Donald Hall, Laurence Helfer, Mark Kelman, Nancy King, Mark Osiel, William Schabas, Robert Weisberg and Beth Van Schaack for helpful criticism of earlier drafts. This Article also benefited from presentations at the Annual Meeting of the American Society of International Law, Washington \& Lee University School of Law, and Boalt Hall's International Law Workshop. For superior research assistance, we thank Emily Urban of the Vanderbilt Law School Library, Phillip Riblett of Vanderbilt Law School, Elizabeth Muli of Stanford Law School, as well as Paul Lomio and Erica Wayne of the Stanford Law School Library. We are also grateful to the editors of the California Law Review. 
d. Nuremberg Revisited: Contemporary JCE, Conspiracy, and Criminal Organizational Liability ....... 117

B. The Development of Command Responsibility......................... 120

1. Doctrinal Overview ......................................................... 120

2. The Origins of Command Responsibility Doctrine.............. 122

3. Evolution of Command Responsibility Doctrine ................. 124

a. Mens Rea Requirement............................................... 125

b. Superior-Subordinate Relationship Requirement .......... 130

IV. Applying the Framework: Joint Criminal Enterprise and Command Responsibility ........................................................... 131

A. Joint Criminal Enterprise ...................................................... 132

1. Influence of Human Rights ............................................... 132

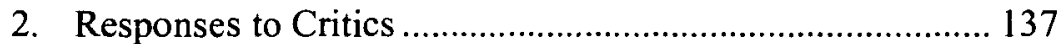

3. The Argument for a More Limited JCE ............................ 142

B. Command Responsibility...................................................... 146

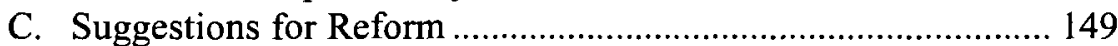

1. JCE: Requiring a Substantial Contribution ......................... 150

2. Specific Intent Crimes ........................................................ 151

3. The Relationship Between JCE and Command Responsibility.

V. The Future of Joint Criminal Enterprise and Command

Responsibility in International and Domestic Adjudication ............. 154

A. Other International Courts ..................................................... 154

1. The Continuing Vitality of Joint Criminal Enterprise.......... 154

2. Command Responsibility: The Example of Abu Ghraib .... 156

B. Domestic Prosecution of International Terrorists ...................... 159

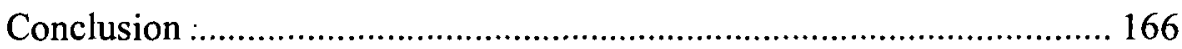




\title{
Guilty Associations: Joint Criminal Enterprise, Command Responsibility, and the Development of International Criminal Law
}

\author{
Allison Marston Danner and Jenny S. Martinez
}

Contemporary international criminal law is largely concerned with holding individual defendants responsible for mass atrocities. Because the crimes usually involve the concerted efforts of many individuals, allocating responsibility among them is of critical importance. This Article examines two liability doctrines-joint criminal enterprise and command responsibility - that play a central role in that allocation of guilt in international criminal tribunals. The Article posits a general framework for understanding the development of international criminal law as an outgrowth of three legal traditions: domestic criminal law, international human rights law, and transitional justice. We explore the application of that framework to joint criminal enterprise and command responsibility doctrines and argue that viewing joint criminal enterprise and command responsibility through the lens of our framework shows the need for certain doctrinal reforms. Finally, we discuss the application of liability doctrines developed in the context of international criminal tribunals to prosecutions for international or transnational crimes in other forums, such as domestic military tribunal prosecutions of terrorists, that do not share the same roots as international criminal law.

\section{INTRODUCTION}

International criminal law represents an extraordinary undertaking. Its prosecutors charge individuals with acts of unimaginable violence: mass executions, sexual enslavement, and brutal mutilations. It is not only the subject matter of international criminal trials, however, that challenges ordinary assumptions. The idea of applying legal rules and standards to the complex and chaotic backdrop of contemporary armed conflicts and episodes of mass atrocity is a bold--some would say futile--effort to fix individual responsibility for history's violent march.

Procedurally, international criminal law is equally ambitious. 1t seeks to meld two legal systems into a coherent whole; international criminal 
tribunals combine aspects of the common law adversarial system with the civil law inquisitorial system. In a formal sense, their rules of procedure and evidence draw on both legal traditions ${ }^{1}$; in a practical sense, judges schooled in the common law or the civil law reflect their system of origin in their approach to various legal problems. The combination of these two divergent traditions has led to certain tensions in doctrine and procedure. ${ }^{2}$

In this Article, we argue that, beyond the clash of the common and civil law traditions, a different and more enduring conflict emerges from the statutes, rules, and decisions of international criminal courts. Contemporary international criminal law combines three distinct traditions: international human rights law, domestic criminal law, and transitional justice. Each one, to varying degrees, informs the purposes and principles of international prosecution, and their interaction creates conflicts within international criminal law itself.

To illustrate these tensions in international criminal law, we examine two doctrinal areas in which they have played out-command responsibility and joint criminal enterprise (JCE). ${ }^{3}$ We focus on these doctrines because they constitute two important theories of individual liability used in contemporary international criminal law; indeed, it is rare to find an international criminal case that does not involve one or both. Conceptually,

1. The Yugoslav and Rwandan Tribunals, for example, take from common law systems an adversarial system for the presentation of evidence, including cross-examination. Drawing on civil law traditions, however, they also employ judges rather than juries, incorporate a more active role for the judges in questioning witnesses (and even in calling their own witnesses), draw more heavily on written evidence prepared in a pre-trial dossier, and allow for appeals by the prosecution. See Diane Marie Amann, Harmonic Convergence? Constitutional Criminal Procedure in an International Context, 75 IND. L.J. 809, 842-43 (2000) (noting that the "judges decide whether charges should go forward" and that "at trial, judges ... decide guilt or innocence") (footnotes omitted); Patrick L. Robinson, Ensuring Fair and Expeditious Trials at the International Criminal Tribunal for the Former Yugoslavia, 11 Eur. J. INT'L L. 569, 574-79 (2000) (noting that the Trial Chamber for the Yugoslav Tribunal can summon and question witnesses, shorten the length of the parties' examination of witnesses, and order the production of additional evidence).

2. See generally Robert Christensen, Getting to Peace by Reconciling Notions of Justice: The Importance of Considering Discrepancies between Civil and Common Legal Systems in the Formation of the International Criminal Court, 6 UCLA J. INT'L L. \& ForeIGN AFF. 391 (2001-2002); Faiza Patel King \& Anne-Marie LaRosa, The Jurisprudence of the Yugoslavia Tribunal: 1994-1996, 8 Eur. J. INT'L L. 123, 125 (1997); Patricia M. Wald, Judging War Crimes, 1 CHI. J. INT'L L. 189 (2000).

3. We principally analyze the jurisprudence of the International Criminal Tribunal for the former Yugoslavia (ICTY) and the International Criminal Tribunal for Rwanda (ICTR), although we also consider the precedents from the International Military Tribunal at Nuremberg (IMT) and its subsequent proceedings, as well as the newly-established International Criminal Court (ICC), the Spccial Court for Sierra Leone, and the Special Panel for Serious Crimes established by the United Nations in East Timor, all of which apply international criminal law and procedure. The Special Court for Sierra Leone and the Special Panel established by UNTAET in East Timor also apply some clements of domestic criminal law. For East Timor, see U.N. TRansitional Administration In East Timor, Reg. No. 2000/i5, on the Establishment of Panels with Exclusive Jurisdiction over Serious Criminal OfFEnSes, at sec. 4-9, U.N. Doc. UNTAET/REG/2000/15 (June 6, 2000). For Sierra Leone, sce United Nations, Sta tute of the Special Court for Sierra Leone, at arts. 1-5, U.N. Doc. S/2002/246, appendix ll (2000), available at http:/www.sc-sl.org/scsl-statute.html. 
these doctrines go to the core of what international criminal trials seek to achieve: the attribution and calibration of individual responsibility for mass atrocities. Furthermore, the study of liability theories presents an ideal vehicle for exploring the moral commitments of international criminal law, for the "doctrines of criminal liability, being generalizations of the conditions in which punishment is proper, are primarily statements of normative import."4

In this Article, we seek to accomplish two goals. The first is to construct a general framework for evaluating doctrinal controversies in international criminal law. We then apply this framework to joint criminal enterprise and command responsibility, providing an explanation for why these doctrines have evolved into their present forms and suggesting ways in which they should be improved. Both doctrines, if not limited appropriately, have the potential to lapse into forms of guilt by association, thereby undermining the legitimacy and the ultimate effectiveness of international criminal law. Doctrinal reforms may help avoid this danger. With regard to joint criminal enterprise, we argue that the scope of the enterprise and the defendant's relationship to it should be defined more precisely. Specifically, international judges should require that prosecutors demonstrate that each defendant charged under a joint criminal enterprise theory made a substantial contribution to the fulfillment of the common objective of the enterprise. In addition, we argue that certain forms of joint criminal enterprise and command responsibility that tolerate a reduced mens rea should not be used in cases involving specific intent crimes such as genocide and persecution. With respect to command responsibility, we argue that something more than ordinary negligence should remain the touchstone for criminal liability.

These suggestions serve to reinforce the idea that an individual may be punished only for conduct for which he is personally responsible. We derive this principle, which we label the principle of individual culpability, from foundational concepts of domestic criminal law systems. In Parts II and IV of this Article we argue that, because of the highly discretionary and, indeed, somewhat arbitrary nature of international criminal law, its legitimacy depends on hewing closely to principles based on personal culpability. Just as many domestic criminal systems justify criminal punishment on this basis, so too must international criminal law anchor its infliction of punishment to morally sound-if not uncontroversialunderpinnings.

Finally, we examine how joint criminal enterprise and command responsibility will affect both the future development of international criminal law and the domestic adjudication of international crimes. The

4. Sanford H. Kadish, Complicity, Cause and Blame: A Study in the Interpretation of Doctrine, 73 Calif. L. Rev. 323, 326 (1985). 
Special Court for Sierra Leone, the Serious Crimes Court in East Timor, and the International Criminal Court have all implicitly or expressly incorporated joint criminal enterprise and command responsibility into their statutory structure. The military commissions instituted by the U.S. government to try suspected terrorists include both command responsibility and a liability theory that closely resembles joint criminal enterprise, and the first indictments of Guantanamo detainees implicitly rely on this joint criminal enterprise theory of liability. ${ }^{5}$ Some experts in international criminal law have suggested that Saddam Hussein be charged using a theory of joint criminal enterprise. ${ }^{6}$ Whether or not senior U.S. officials may be charged with violations in connection with the Abu Ghraib prison scandal depends in part on the application of command responsibility principles. ${ }^{7}$

These developments also suggest that international tribunals ought to proceed with greater awareness of the possibility that the law they develop may be applied in other contexts they cannot yet foresee. Human rights advocates may applaud when an international court uses an expansive version of joint criminal enterprise doctrine to hold a particular defendant liable for the range of crimes associated with the ethnic cleansing of a region in which he played some part. But, they may wish the doctrine had been more carefully defined when it is later used by a national government to suggest that all persons who provide any sort of support to a terrorist organization, however loosely defined, thereby become liable for all crimes committed by its members.

Framing InTERNATIONAL CRIMINAL LAW

International criminal law sits at the confluence of several important bodies of law. Genealogically, it grows out of international humanitarian law, sometimes referred to as the laws of war. ${ }^{8}$ International humanitarian law provides the source of many of the crimes of international criminal

5. Press Release, U.S. Dep't of Defense, Guantanamo Detainee Charged (June 10, 2004), at http://www.defenselink.mil/releases/2004/nr20040610-0893.html (containing defendant's indictment, which charges that he "knowingly joined an enterprise of persons who shared a common criminal purpose"); Press Release, U.S. Dep't of Defense, Two Guantanamo Detainees Charged (Feb. 24, 2004), at http:/www.defenselink.mil/releases/2004/nr20040224-0363.html (stating that defendants "are charged with willfully and knowingly joining an enterprise of persons who shared a common criminal purpose").

6. Peter Slevin, The Trial of Hussein: Choosing the Evidence, WASH. Post, Jan. 2, 2004, at Al (stating that Saddam Hussein could be prosecuted under a command responsibility or joint criminal enterprise theory).

7. The Abu Ghraib prison scandal is discussed further in Part V. See text accompanying notes 356-70.

8. International humanitarian law (the modern name for the law of war or jus in bello) regulates the methods, targets, and means of waging armed conflict. LesLie C. GREen, THE Contemporary LAW OF ARMED CONFLICT 17-19 (2d ed. 2000). 
law ${ }^{9}$ and presages some of the field's normative goals. ${ }^{10}$ To describe international humanitarian law as an "influence" on international criminal law understates its importance; the latter field emerged directly from the former. Contemporary international criminal law, ${ }^{11}$ however, also draws from three other legal traditions: domestic criminal law, human rights law, and transitional justice. Although these influences are distinct, they do share important elements. Human rights law includes protections for criminal defendants. Criminal trials constitute a major element of transitional justice. Transitional justice proceedings often focus on the human rights violations committed by the ancien régime.

Nevertheless, certain essential features of each of these traditions can be distilled and contrasted. To more clearly describe them, our account

9. The statutes of the ICTY and ICTR both pay homage to international criminal law's roots in this field by calling for prosecution of "serious violations of intemational humanitarian law." SECURITY Council of the U.N., Statute of the International Criminal Tribunal for the former Yugoslavia, at art. 1 (2004) [hereinafter ICTY Statute]; Security Council of the U.N., STatuTE of the International Criminal Tribunal for Rwanda, at art. I, U.N. Doc. S/Res/955 (1994) [hereinafter ICTR STATUTE]. The ICTY's Statute likewise retains the requirement that crimes against humanity be "committed in armed conflict," although it includes no such requirement for genocide and that requirement is dropped even for crimes against humanity in both the ICTR and ICC Statutes. ICTY Statute, supra, at art. 5; ICTR Statute, supra, at art. 3; U.N. Diplomatic Conference of Plenipotentiaries on the Establishment of an International Criminal Court, Rome Statute of the International Criminal Court, at art. 7, U.N. Doc A/Conf. 183/9 (I998), available at http://www.un.org/law/icc/statute/romefra.htm [hereinafter ICC STATUTE]. Thus, while war crimes remain a staple of intemational criminal law, since both crimes against humanity and genocide need not be connected with armed conflict, not all international crimes are war crimes. At the same time, international humanitarian law not only creates criminal liability for individuals who violate its strictures but also engenders state responsibility for nations that fail to uphold it. See, e.g., SECOND Peace Conference of the Hague, i 907, Convention (IV) Respecting the Laws and Customs of War on Land and its ANNEX: Regulation Concerning The LaWs and Customs of War on LAND, at art. 3, 187 CTS 227 (1907) [hereinafter HAGUE CONVENTION (IV)]. International criminal law does not address state responsibility. For these reasons, it is no longer accurate to speak of the two fields interchangeably.

10. International humanitarian law has its modern origins in mid-19th century developments that culminated with the codification of laws and customs of war in the 1899 and 1907 Hague Conventions. Aside from the substantive rules it lays out, the 1907 Hague Convention (and the preceding developments in international humanitarian law that it reflects and codifies) is notable in two respects. First, it regulates states' obligations to individual persons, not merely to other states. HAGUE Convention (IV), supra note 9, at pmbl. This development foreshadows the increasing willingness of intemational law to concern itself with the behavior of states towards even their own citizens; in this respect it is a precursor to international human rights law. Second, it imposes duties of conduct on individual persons, not just nation-states, by requiring that troops be commanded by a leader "responsible for his subordinates." Id. at ch. I art. I. This provision demonstrates an awareness that individual persons are the mechanism by which state's legal obligations are carried out and thus must be considered as part of any effective enforcement strategy. This aspect makes it a precursor to international criminal law in a broad methodological sense, and not simply in the narrow sense of being the substantive source of the norms enforced in the first international criminal proceedings. Indeed, this focus on individual liability is one feature that distinguishes international humanitarian law and international criminal law from human rights law.

11. By contemporary, we mean international criminal law of the post-World War II period, and more specifically, the international criminal law that has developed since the establishment of the ICTY in 1993. See S.C. Res. 827, U.N. SCOR, 48th Sess., at 1-2 (1993). 
emphasizes their differences instead of their shared qualities. This approach is not only justified, but necessary, to understand the development of international criminal law and to construct an account for how its doctrines can and should be improved. For what this approach reveals is that the three traditions informing contemporary international criminal law are not always complementary. They are, in important ways, deeply at odds.

\section{A. Domestic Criminal Law}

As its name implies, international criminal law is a system of criminal law. Existing international criminal courts exclusively punish individuals ${ }^{12}$ (as opposed to other types of legal entities, such as states or corporations), ${ }^{13}$ and imprisonment constitutes the principal form of punishment imposed. ${ }^{14}$ Principles derived from domestic criminal law have played an important role in the development of international criminal law. ${ }^{15}$ Judges from the International Criminal Tribunal for the former Yugoslavia (ICTY) and the International Criminal Tribunal for Rwanda (ICTR) have frequently employed comparative criminal law analysis to fill in lacunas in the tribunals' statutes. ${ }^{16}$

At a deeper level, international criminal law has adopted key philosophical commitments of national criminal justice systems. The most important of these is the focus on individual wrongdoing as a necessary prerequisite to the imposition of criminal punishment. International criminal law, like most municipal criminal law systems, maintains that

12. The Judgement of the International Military Tribunal at Nuremberg is the canonical source for this proposition. It declared, "[c] rimes against international law are committed by men, not by abstract entities, and only by punishing individuals who commit such crimes can the provisions of international law be enforced." INTERnational Military Tribunal, Judgement, in Trial of the Major War Criminals Before the International Military Tribunal: Nuremberg, I4 NOVEMBER I945-I OCTOBER I946, 171, 223 (1947) Ihereinafter Nuremberg Judgement].

13. Although none of the statutes of the existing international criminal fora explicitly provides for such prosecutions, some scholars argue that corporations may be punishable under customary international law. See, e.g., Beth Stephens, The Amorality of Profit: Transnational Corporations and Human Rights, 20 BERKELEY J. INT'L L. 45, 73-78 (2002)

14. The International Criminal Court may also, in addition to imprisonment, order that a fine be imposed on a convicted person and that he forfeit property or assets derived from the crime. 1CC STATUTE, supra note 9 , at art. 77. The 1CC may also order a convicted person to make reparations to the victim. Id. at art. 75 .

15. For a criticism of this transposition of domestic criminal law into the international sphere, see Immi Tallgren, The Sensibility and Sense of International Criminal Law, 13 EUR. J. INT'L L. 561 (2002).

16. Judges have turned to domestic criminal law doctrines, for example, when construing the contours of a duress defense and developing double jeopardy principles. Prosecutor v. Delalić, Judgement, 1CTY Appeals Chamber, at paras. 400-413, Case No. 1T-96-21-A (Feb. 20, 2001) (discussing approaches and ultimately adopting the test articulated in Blockburger v. United States, 284 U.S. 299, 304 (1932)) [hereinafter Čelebići Appeals Judgement]; Prosecutor v. Erdemović, Joint Separate Opinion of Judge McDonald and Judge Vorhah, ICTY Appeals Chamber, at paras. 59-65, Case No. 1T-96-21-A (Oct. 7, 1997) (considering the applicability of a duress defense based on a comparison of the domestic laws of civil and common law nations). 
"punishment may not justly be imposed where the person is not blameworthy." 17 Indeed, "[u]nderlying the great bulk of the doctrines of the criminal law is the conception of personal responsibility." 18

As Mirjan Damaška notes, the evolution of the criminal law from its early days of collective tribal guilt reveals a steady progression toward fixing punishment based solely on responsibility for one's own actions and personal degree of culpability. ${ }^{19}$ The German Criminal Code, for example, declares that "the guilt of the perpetrator is the basis for determining punishment." ${ }^{.20}$ Similarly, the French Criminal Code states that "one may be held criminally responsible only for his own actions."21 Although contemporary municipal criminal systems have, in many ways, strayed significantly from the culpability principle in practice, it still provides a leading theoretical and moral basis for criminal punishment.

Domestic criminal law systems instantiate the goal of limiting punishment to blameworthy individual wrongdoing through a variety of substantive and procedural doctrines. In the Anglo-American tradition, for example, the act requirement precludes the state from punishing individuals based solely on bad thoughts that have not been translated into concrete action. ${ }^{22}$ The principle of legality requires that criminal statutes provide fair warning that a particular act may be punishable as a crime. ${ }^{23}$ Indeed, most if not all modern legal systems prevent the imposition of criminal punishment for actions that were not a crime when taken. ${ }^{24}$ The German

17. Sanford H. Kadish, Why Substantive Criminal Law-A Dialogue, in Blame and Punishment 3, 12 (1987).

18. Id.

19. Mirjan Damaška, The Shadow Side of Command Responsibility, 49 Aм. J. Comp. L. 455, 470 (2001) ("[I]f one were to catalog general principles of law so widely recognized by the community of nations that they constitute a subsidiary source of public international law, the culpability principle would be one of the most serious candidates for inclusion in the list."); Daryl J. Levinson, Collective Sanctions, NYU Law School, Public Law Rcsearch Paper No. 57, at 3 ("Liberal conceptions of morality insist that agency and responsibility be attributed only to individuals, not groups."), available at http://ssrn.com.

20. $\S 46$ Nr. 1 Sozialgesetzbuch (StGB) (F.R.G.) (trans. by the Federal Ministry of Justice).

21. CODE PÉNAL [C. PÉN] art. 121-1 (Fr.) (author's trans).

22. 4 William BLACKSTONE, COMMENTARIES *21 ("[T]o make a complete crime, cognizable by human laws, there must be both a will and an act."); 2 Wayne R. LAFAVE, Substantive Criminal LAw 209 (4th ed. 2003).

23. See, e.g., Connally v. General Constr. Co., 269 U.S. 385, 391 (1925).

24. Norman Dorsen et al., Comparative Constitutionalism: Cases and Materials 1140 (2003); George P. Fletcher, Basic ConCePts of Criminal Law 207 (1998); e.g., U.S. CONST. art. I $\S \S 9,10$; C. PÉN. art. 112-1; $§ 1$ Strafprozeßordnung (StPO) (F.R.G.). In international human rights law, this prohibition against ex post facto punishment is captured by the principle nullum crimen sine lege, nulla poena sine lege (no crime without law, no penalty without law). See, e.g., International Covenant on Civil and Political Rights, Dec. 19, 1966, 999 U.N.T.S. 171, at art. 15(1) (entered into force Mar. 23, 1976) [hereinafter I.C.C.P.R.] ("No onc shall be held guilty of any criminal offence on account of any act or omission which did not constitute a criminal offence, under national or international law, at the time when it was committed."). It is described as a non-derogable right in the major international human rights treaties that address political and civil rights. Dinah Shelton, 
Constitution states that "an act can be punished only if it was a punishable offence by law before the act was committed." 25

This emphasis on deliberate wrongdoing as the only permissible basis for punishment also finds support in the widespread requirement that ambiguous criminal statutes be construed in accordance with the interpretation most favorable to the accused, often referred to as the rule of lenity. ${ }^{26}$ Prohibitions against overly vague criminal statutes (sometimes described as the requirement of specificity) also focus the criminal sanction on an individual's choice to engage in deliberate wrongdoing. ${ }^{27}$

These doctrines, derived from municipal criminal law systems, and the culpability principle they seek to implement, have been absorbed into international criminal law. The ICTY Appeals Chamber has underscored that the "basic assumption" in international and national laws is that "the foundation of criminal responsibility is the principle of personal culpability."28 The prohibition against ex post facto punishment finds clear support in international criminal law. ${ }^{29}$ One of the ICTY Trial Chambers has stated that the prohibition on ex post facto punishment and the rule of lenity "are the solid pillars on which the principle of legality stands. Without the satisfaction of these principles no criminalisation process can be accomplished and recognized." 30 Other ICTY and ICTR Trial Chambers

Hierarchy of Norms and Human Rights: Of Trumps and Winners, 65 SASKATCHEWAN. L. REv. 299, 314 (2002).

25. Art. 103(2) Grundgesetz [GG] (F.R.G.) (trans. by Federal Ministers of the Interior, Justice and Finance).

26. See, e.g., C. PÉn art. 111-4, reprinted in The French Penal Code of 1994 As Amended as of JANuarY I, I 999, at 31 (Edward A. Tomlinson, trans., The American Series of Foreign Penal Codes No. 31, 1999); United States v. Lanier, 520 U.S. 259, 266 (1997) (noting that "the canon of strict construction of criminal statutes, or rule of lenity, ensures fair warning by so resolving ambiguity in a criminal statute as to apply it only to conduct clearly covered").

27. See City of Chicago v. Morales, 527 U.S. 41 (1999).

28. Prosecutor v. Tadić, Judgement, ICTY Appeals Chamber, at para. 186, Case No. 1T-94-1-A (July 15, 1999) [hereinafter Tadić V].

29. The ICTY Appeals Chamber has highlighted that "it is every Chamber's duty to ascertain that a crime or a form of liability charged in the indictment is both provided for under the Statute and that it existed at the relevant time under customary international law." Proseeutor v. Multinović, Decision on Dragoljub Ojdanić's Motion Challenging Jurisdiction-Joint Criminal Enterprise, ICTY Appeals Chamber, at para 17, Case No. 1T-99-37-AR72 (May 21, 2003). The "legislative history" of the statutes of the ICTY and ICTR unequivocally indicates that these courts have jurisdiction only over crimes proscribed by international criminal law at the time of the commission of the crimes. The SecretaryGeneral's Report on the ICTY Statute states that:

In the view of the Secretary-General, the application of the principle nullum crimen sine lege requires that the international tribunal should apply rules of international humanitarian law which are beyond any doubt part of customary law.... This would appear to be particularly important in the context of an international tribunal prosecuting persons responsible for serious violations of international humanitarian law.

Secretary-General of the U.N., Report of the Secretary-General Pursuant to Paragraph 2 of Security Council Resolution 808, at para. 34, U.N. Doc. S/25704 and Add. 1 (1993).

30. Prosecutor v. Delalić, Judgement, 1CTY Trial Chamber, at para. 402, Case No. 1T-96-21-T (Nov. 16, 1998). 
have also recognized the application of the rule of lenity to international criminal law. ${ }^{31}$ Still others have endorsed a void for vagueness doctrine, refusing to convict defendants for crimes they viewed as unduly vague under customary international law. ${ }^{32}$ The Statute of the International Criminal Court likewise prohibits the retroactive imposition of criminal punishment and requires that criminal statutes be strictly construed and not extended by analogy. ${ }^{33}$ While not all of these doctrines equally protect the culpability principle, they all serve it in some fashion.

These specific procedural and substantive criminal law doctrines, and the culpability principle they help defend, distance the liberal trial from the charge of basing guilt on association alone. As the U.S. Supreme Court has observed, guilt by association is a "thoroughly discredited doctrine." 34 One of the most famous passages from the judgement of the International Military Tribunal at Nuremberg declares that the Tribunal's conclusions were made "in accordance with well-settled legal principles, one of the most important of which is that criminal guilt is personal, and that mass punishments should be avoided." ${ }^{35}$ At its most fundamental level, then, the paradigm of domestic criminal law advanced in this Article, which has been adopted by international criminal law as a fundamental principle, links punishment to individual wrongdoing and eschews findings of liability based simply upon association with other wrongdoers. ${ }^{36}$

Some scholars have attacked the culpability paradigm, with its roots in Kantian liberal theory, as inapplicable to the context in which international crimes are committed. Others argue that the culpability paradigm

3I. See, e.g., Prosecutor v. Kayishema, Judgement, ICTR Trial Chamber, at para. 103, Case No. ICTR-95-I-T (May 21, 1999) ("The Trial Chamber agrees that if a doubt exists, for a matter of statutory interpretation, that doubt must be interpreted in favour of the accused."); Prosecutor v. Delalić, Judgement, ICTY Trial Chamber, supra note 30 at para. 408 ("To put the meaning of the principle of legality beyond doubt, two important corollaries must be accepted. The first of these is that penal statutes must be strictly construed, this being a general rule which has stood the test of time. Secondly, they must not be given retroactive effect."). But see William A. Schabas, Interpreting the Statutes of the Ad Hoc Tribunals, in MAN's INHUMANITY TO MAN: ESSAYS ON INTERNATIONAL LAW IN Honour of ANTONIo CASSESE 846, 886 (Lal Chand Vohrah et al. eds., 2003) (arguing that strict construction has rarely been used by the ad hoc tribunals).

32. Prosecutor v. Vasiljević, Judgement, ICTY Trial Chamber, at para. 20I, Case No. IT-98-32-T (Nov. 29, 2002) ("[T] The Trial Chamber must satisfy itself that this offence with which the accused is charged was defined with sufficient clarity under customary international low for its general nature, its criminal character and its approximate gravity to have been sufficiently foreseeable and accessible."). This Trial Chamber refused to convict the defendant of "violence to life and person" because of the "absence of any clear indication in the practice of states as to what the definition of the offence ... may be under customary law." Id. at para. 203.

33. ICC STATUTE, supra note 9, at art. 22.

34. Uphaus v. Wyman, 360 U.S. 72,79 (1959).

35. Nuremberg Judgement, supra note 12, at 256.

36. See Marco Sassòli \& Laura M. Olson, The Judgement of the ICTY Appeals Chamber on the Merits in the Tadic Case, 82 INT'L REv. RED CROss 733, 755 (2000) ("[T] he very basis of international criminal law and its civilizing contribution to the enforcement of international law is that criminal responsibility is individual."). 
provides a theoretical justification for liberal systems of criminal law but, in practice, is often violated. We discuss these objections in Part IV of this Article. Whatever the ultimate merits of these arguments, the criminal doctrines employed by international criminal law courts are undeniably premised on the notion of individual moral (and therefore criminal) responsibility for choices to harm others. These doctrines, originating in domestic criminal law systems and adopted into international criminal law, reveal the extent to which international criminal law constitutes an extension of the application of domestic criminal law principles onto the international forum.

\section{B. Human Rights}

If justifying the deprivation of personal liberty-one of the most precious of liberal values-poses the central philosophical problem of criminal law, institutions enforcing international human rights rarely need to justify so gross an assertion of power. While criminal law is law at its most coercive ${ }^{37}$ international human rights law has been law at its most gentleindeed, so gentle that some question whether it really is "law" at all. . $^{38}$

Institutions responsible for interpreting and adjudicating human rights violations do not have the authority to imprison offenders; typically their most intrusive remedy is to provide "just satisfaction" for the injured party in the form of money damages or some other remedy. ${ }^{39}$ Human rights law relies on civil and administrative mechanisms for domestic enforcement. ${ }^{40}$ States may also be required to change domestic laws to respond to rulings from human rights tribunals. For much human rights litigation, however, the largely symbolic finding of state wrongdoing represents the most farreaching goal of the litigation. Much of international human rights practice does not involve litigation at all; non-binding reports are a staple of many international human rights bodies. Indeed, the symbolic promotion of human rights norms is a major goal of international human rights law, in

37. See Robert M. Cover, Violence and the Word, 95 YALE L.J. 1601, 1606 (1986) (describing the "violence of the act of sentencing").

38. See Oona A. Hathaway, Do Human Rights Treaties Make a Difference?, 111 Yale L.J. 1935, $1937-47$ (2002) (describing realist international theorists' skepticism about the effectiveness of international human rights law).

39. Diane F. Orentlicher, Addressing Gross Human Rights Abuses: Punishment and Victim Compensation, in Human Rights: An Agenda for the Next Century 425, 454 (Louis Henkin \& John Lawrence Hargrove eds., 1994).

40. M. Cherif Bassiouni, Enforcing Human Rights Through International Criminal Law and Through an International Criminal Tribunal, in Human Rights: AN AgENDA FOR THE Next CENTURY, supra note 39 , at 347,351 . 
the hope that state behavior will eventually conform to norms adopted and recognized as legitimate by the world community. ${ }^{41}$

Beyond the power of their distinct sanctions, human rights and criminal law differ widely in other respects. Although criminal law serves collective social goals such as deterrence, retribution, and rehabilitation, its central focus is on individual wrongdoing. Whatever broader social trends the crime may grow out of and whatever ripple effects the criminal trial might have, the legal focus of the trial is narrow: determining the past acts and the ultimate fate of the individual defendant. ${ }^{42}$ By contrast, human rights law is largely victim, not perpetrator, centered. It concentrates on establishing the veracity of allegations that individuals' human rights have been violated and, to that end, often focuses on fact-finding related to broad social phenomena. It frequently refuses to fix responsibility on individuals for the perpetration of these violations.

The reluctance to make determinations of individual responsibility for wrongdoing flows from the legal structure of international human rights law. Under international law principles, the nation-state as a whole--and not individual government officials - is liable for a violation of its citizens' human rights. This aspect of human rights law reflects its legal origins as a subset of the general international law of state responsibility. ${ }^{43}$ This branch of public international law provides the liability rules for determining when states may be found in violation of their substantive international legal obligations. $^{44}$

Consonant with the rules of state responsibility, in international human rights law the identity of the particular official actor who actually violates the victim's human rights is often irrelevant. ${ }^{45}$ The mental state of the offending individual, if known, is similarly immaterial. ${ }^{46}$ The Inter-American Court of Human Rights has declared that a human rights

41. Cf. Hathaway, supra note 38 , at 2021 (describing how human rights treaties, even if not initially obeyed, may ultimately "influence individual countries' perceptions of what constitutes acceptable behavior").

42. In civil law systems the criminal defendant may also be required to pay compensation to the victims at the end of the trial. Beth Van Schaack, In Defense of Civil Redress: The Domestic Enforcement of Human Rights Norms in the Context of the Proposed Hague Judgements Convention, 42 HARV. INT'L L.J. 141, 143, 145-46 (2001).

43. Dorothy Q. Thomas \& Michele E. Beasley, Domestic Violence as a Human Rights Issue, 58 ALB. L. REv. 1119,1124 (1995) (noting that "It]he concept of state responsibility defines the limits of a government's accountability for human rights abuses under international law").

44. See generally Repart of the International Law Commission on the Work of Its Fifty-third Session, UN GAOR International Law Commission, 55th Sess., Supp. No 10, U.N. Doc. A/56/10 (2001), available at $\mathrm{http}: / /$ www.un.org/law/ilc/, reprinted in THE INTERNATIONAL LAw COMMISSION's articles on State Responsibility: Introduction, Text and Commentaries (James Crawford ed., 2002).

45. André Nollkaemper, Concurrence Between Individual Responsibility and State Responsibility in International Law, 52 lNT'L \& CoMP. L.Q. 615, 616 (2003) ("State responsibility neither depends on nor implies the legal responsibility of individuals.").

46. Id. at 617 . 
violation can be found "even if the identity of the individual perpetrator is unknown. What is decisive is whether a violation of the rights recognized by the Convention has occurred with the support or the acquiescence of the government ..."47 Similarly, the European Court of Human Rights does not generally ascribe responsibility within a state for human rights violations. $^{48}$

The Inter-American Court of Human Rights has succinctly captured the distinction between a human rights proceeding and a criminal trial:

The international protection of human rights should not be confused with criminal justice. States do not appear before the Court as defendants in criminal action. The objective of international human rights law is not to punish those individuals who are guilty of violations, but rather to protect the victims and to provide for the reparation of damages resulting from the acts of the States responsible. ${ }^{49}$

While both human rights law and criminal law share the deterrence of violations as a major goal, ${ }^{50}$ they implement this goal differently. Unlike criminal law, which relies heavily on the threat of punishment for its deterrent effects, human rights practice rests more heavily on the indirect punishment of public shaming and, perhaps even more importantly, on forward-looking remedies like capacity building. The United Nations Human Rights Commission, for example, views a major part of its mission as setting standards and helping national governments implement those standards. These goals are accomplished through reporting mechanisms aimed at improving practices by exposing them to public scrutiny and also through "expert advice, human rights seminars, national and regional training courses and workshops, fellowships and scholarships, and other activities aimed at strengthening national capacities for the protection and promotion of human rights."

47. Velasquez Rodriguez Case, Judgement of July 29, 1988, Inter-Am. Ct. H.R. (Ser. C), No. 4, at para. 173 (1988) [hereinafter Velasquez Rodriguez].

48. See J. G. Merrills, The Development of Interna tional Law by the European Court of Human Rights 11 (2d ed. 1993) (stating "what is in issue is the international responsibility of the State") (footnote omitted).

49. Velasquez Rodriguez, supra note 47 , at para. 134. Similarly, the ICTY has underscored that "the role and position of the state as an actor is completely different in both regimes .... Structurally, this has been expressed by the fact that human rights law establishes lists of protected rights while international criminal law establishes lists of offences." Prosecutor v. Kunarac, Trial Judgement, at para. 470, Case No. IT-96-23-T \& IT-96-23/1-T (Feb. 22, 2001).

50. See, e.g., Jordan J. Paust, The Significance and Determination of Customary International Human Rights Law: The Complex Nature, Sources, and Evidences of Customary Human Rights, $25 \mathrm{GA}_{\mathrm{A}}$ J. INT'L COMP. L. 147, 160 (1995-1996) (describing goals of human rights law as including "prevention, deterrence, restoration, rehabilitation, reconstruction, and correction").

51. See Office of the High Commissioner for Human Rights, Commission on Human RIGHTS, Main Themes, at http://www.unhchr.ch/html/menu2/2/chrintro.htm (last visited Sept. 8, 2004). 
rather than its punishment, constitutes the principal focus of human rights law.

To be sure, despite these differences there is some overlap between criminal law and human rights law. For example, human rights law includes specific provisions governing criminal trials. ${ }^{52}$ In some legal systems, the defendant-centered tendencies of the criminal trial are moderated by mechanisms allowing for participation in the trial by the victim. ${ }^{53}$ In several fundamental ways, however, the working presumptions of human rights law and criminal law present mirror images of each other. In a criminal proceeding, the focus is on the defendant and the burden is on the prosecuting authority to prove that the individual before the court has committed a crime. Ambiguity about that assertion is to be construed in favor of the criminal defendant, and the trier of fact is charged with determining what the defendant did and what his mental state was toward the acts constituting the crime. In human rights proceedings, by contrast, the focus is on the harms that have befallen the victim and on the human rights norm that has been violated. One consequence of this focus is that the substantive norms of international human rights law are generally broadly interpreted to ensure that harms are recognized and remedied, and that, over time, there is progressively greater realization of respect for human dignity and freedom. ${ }^{54}$ The analogous rules of domestic criminal law, by contrast, are supposed to be strictly construed in favor of the defendant. And while criminal law tends toward the specific and the absolute, human rights law embraces some contingent, aspirational norms. ${ }^{55}$

52. International human rights law has, therefore, to some extent, reinforced the principles protecting individual punishment for culpable conduct described above. The ICTY and ICTR have frequently referenced the decisions of human rights tribunals, particularly the European Court of Human Rights, when assessing defendants' rights. The ICTY, for example, has referred to decisions from the European Court of Human Rights when assessing the scope of the right to counsel, the length of pre-trial detention, and the legality of arrest procedures. Göran Sluiter, International Criminal Proceedings and the Protection of Human Rights, 37 New ENG. L. REv. 935, 938-39, 944-45 (2003); see generally Salvatore Zappalà, human Rights in 1nternational Criminal Proceedings (2003) (describing role of human rights law in intemational criminal proceedings).

53. See Van Schaack, supra note 42, at 143 (describing mechanisms in some legal systems for allowing participation in the trial by the victim).

54. See Laurence R. Helfer, Overlegalizing Human Rights: International Relations Theory and the Commonwealth Caribbean Backlash Against Human Rights Regimes, 102 Colum. L. REv. 1832, 1887 (2002) (noting "[n]orm shifts are particularly prevalent in the human rights arena, where treaties under the stewardship of international tribunals have been imbued with an inherently expansionist character"); $c f$. Van Schaack, supra note 42, at 14 I ("Unless recovery is allowed in each instance where there has been a violation of a right, the violations will be repeated with impunity, and that which is wrong will come to be regarded as something right. Unless it is faced and dealt with, wrong will have the same stature as right.") (quoting J.D. LeE \& BARRY A. LiNDAHL, MODERN TORT LAW $§$ I.0I, at 2 (rev. ed. 1988)).

55. See, e.g., International Covenant on Econounic Social and Cultural Rights, Dec. 16, 1966, 993 U.N.T.S. 3 (entered into force Jan. 3, 1976) ("Each State Party to the present Covenant undertakes to take steps ... to the maximum of its available resources, with a view to achieving progressively the full realization of the rights recognized in the present Covenant by all appropriate means ...."); Universal 
The confluence in international criminal law between criminal law principles drawn from domestic criminal law and the philosophical commitments of international human rights law sets up two opposing optics with which to adjudicate a violation. Should it be in the defendant-centered mode of a criminal trial or the victim-oriented style of a human rights proceeding? Should it hew to the rule of lenity that protects defendants from unexpected expansions of the law, or should it reflect the aspirational character of international human rights law? As the following parts of this Article demonstrate, these conflicting tensions surface in important ways in the jurisprudence of international criminal law.

\section{Transitional Justice}

Transitional justice has been defined as the "conception of justice associated with periods of political change, characterized by legal responses to confront the wrongdoings of repressive predecessor regimes." 56 Although the term has been applied retrospectively to describe the post-World War II trials of the major Nazi war criminals before the International Military Tribunal (IMT) at Nuremberg, the notion of transitional justice came into widespread use in the 1990s as a way of characterizing the legal components of the political transitions in many Latin American countries emerging from military dictatorships, in Eastern European countries abandoning communism, and in South Africa's passage from apartheid to multiracial democracy. ${ }^{57}$

While the focus of transitional justice is often backward looking, insofar as the legal system seeks to address the crimes of a predecessor government, its goals are forward looking. Transitional justice uses a variety of legal mechanisms-including criminal trials - to reinforce political transition from one regime to another. Thus, it serves a variety of ends, including reestablishing the rule of law, entrenching democratically accountable

Declaration of Human Rights, G.A. Res. 217A, U.N. GAOR, pt.1, at 71, U.N. Doc. A/810 (1948) (" $[E]$ very individual and every organ of society ... shall strive by teaching and education to promote respect for these rights and freedoms and by progressive measures, national and international, to secure their universal and effective recognition and observance ...."). Not all international human rights law is contingent or aspirational, of course; some rights are considered non-derogable. See I.C.C.P.R., supra note 24 , at art. 4 .

56. Ruti G. Teitel, Transitional Justice Genealogy, 16 Harv. HuM. RTs. J. 69, 69 (2003) (citations omitted).

57. Id. at 71. For representative discussions of the topic of transitional justice, see, e.g., RUTI G. Teitel, Transitional Justice (2000); Transitional Justice and the Rule of Law in New Democracies (A. James McAdams ed., 1997); Transitional Justice: How Emerging Democracies Reckon with Former Regimes (Neil J. Kritz ed., 1995). Eric Posner and Adrian Vermuele have recently criticized the notion that transitional justice is a "distinctive topic presenting a distinctive sct of moral and jurisprudential dilemmas." They argue instead that it is "continuous with ordinary justice," while simultaneously defending the use of "trials and other processes designed to punish or remove officials and collaborators of the old regime" under principles of ordinary justice. Eric A. Posner \& Adrian Vermuele, Transitional Justice as Ordinary Justice, 117 HARv. L. REv. 761, 764 (2004). 
institutions, promoting societal peace and reconciliation, deterring future violations, and providing a measure of redress to victims. ${ }^{58}$ These goals often pull in contradictory directions: will high-profile punishments of past wrongdoers lead to societal peace and reconciliation, or add salt to old wounds and perpetuate the hatreds that led to the violations in the first place ${ }^{59}$ Because of the difficult, context-specific calibration that transitional justice demands, criminal prosecutions make up but one component of the transitional justice toolbox, which also includes truth commissions, amnesties, lustration, reparations, and civil proceedings seeking monetary damages. In South Africa, for example, the choice was made to give individual grants of amnesty in exchange for full and public confessions, and a Truth and Reconciliation Commission was created in lieu of any attempt to criminally prosecute all the participants in apartheid. ${ }^{60}$

While criminal trials are not the only transitional justice mechanism, they are a valuable and venerable one. Historically, domestic legal systems have regularly used criminal trials to mark political transitions and discredit prior regimes. The treason trial of King Charles I of England in 1649 was an attempt to legitimize the transition away from the Stuart monarchy. In the Restoration of the monarchy a decade later, those responsible for Charles I's execution were themselves put on trial-including the deceased Oliver Cromwell, whose body was dug up for the trial and subsequently "executed."61 France's King Louis XVI was likewise put on trial and executed during the French Revolution. ${ }^{62}$ This historical tradition reached an ignominious climax in the political show trials that were a staple of the communist regimes in the former Soviet Union and China. ${ }^{63}$

The modern conception of the international criminal trial as a transitional justice tool is usually traced to the International Military Tribunal at Nuremberg. ${ }^{64}$ Although Nuremberg has been criticized by some as an illegitimate show-trial exemplifying victor's justice, the Nuremberg model contains several components which distinguish it from some of its less worthy predecessors and align it with modern, liberal transitional justice goals. The first is its reliance on univcrsal human rights norms that are said

58. TEITEL, supra note 57, at 220-21.

59. See generally Martha Minow, Between Vengeance and Forgiveness: Facing History After Genocide and Mass Violence (1998).

60. John Dugard, Retrospective Justice: International Law and the South African Model, in Transitional Justice and the Rule of Law in New Democracies 269 (A. James McAdams ed., 1997).

61. Peter Gaunt, Oliver Cromwell 3-4 (1996); C.V. Wedgwood, A Coffin for King Charles: The Trial and Execution of Charles 1, at 253 (1964).

62. Susan Dunn, The Deaths of Louis XVI: Regicide and the French Political lmagination 32-33 (1994); Regicide and Revolution: Speeches at the Trial of Louis XVI, at 4 6 (Marian Rothstein trans., Michael Walzer ed., 1974).

63. Robert C. Tucker, Introduction to The Great Purge Trial, at ix, x-xi (Robcrt C. Tucker \& Stephen F. Cohen eds., 1965).

64. See Teitel, supra note 56, at 72. 
to transcend positive domestic law. In addition to using international norms to trump contrary provisions of domestic law, the transitional trial also delegitimizes the old regime, in part, based on its violation of universal human rights. ${ }^{65}$ lt should be noted, however, that Nuremberg's reliance on universal human rights emerges only with the benefit of historical hindsight. The most important human rights treaties postdate Nuremberg; indeed, the trial is often cited as the beginning of the contemporary human rights movement. ${ }^{66}$

Criminal trials in the transitional context, like the Nuremberg proceedings, also play an overtly political function. As Judith Shklar observed, what distinguishes contemporary transitional trials from the discredited show-trial employed by Stalin is not the political aims of the trial, but "the quality of the politics pursued in them." ${ }^{37}$ In the transitional justice model, trials are harnessed to serve liberal ends, namely the promotion of democracy and the rule of law. ${ }^{68}$ In this way, transitional trials draw a firm line between the domestic politics of the former, discredited regime and the current regime's embrace of democracy and the rule of law.

The internationalization of justice constitutes an additional critical component of the Nuremberg model. Rather than leaving trials up to the new government of the nation in transition, the Nuremberg model relies on an ostensibly impartial international entity applying law from an external, neutral source. While the international community is never entirely disinterested, international judges are viewed by many (although not by all) as less prone to self-dealing than new national government officials, who may be more intent on solidifying their hold on power than in doing justice. ${ }^{69}$ Paradoxically, the internationalization of the trials is also viewed as furthering the new government's hold on power. International trials free the new government from the controversial responsibility of putting the old regime on trial, leaving them free to get about the business of rebuilding without the burden of directly addressing the past. While many transitional trials eschew this aspect of Nuremberg and proceed in a purely domestic

65. See Peter E. Quint, The Border Guard Trials and the East German Past-Seven Arguments, 48 Ам. J. COMP. L. 541, 541-43 (2000) (noting that "[i]n the years following German reunification, the courts have conducted criminal trials of former East German officials for reprehensible actions committed under the old regime").

66. Henry J. Steiner \& Philip Alston, International human Rights in Context: Law, Politics, Morals 112 (2d ed. 2000).

67. Judith N. SHKLAR, Legalism 145 (1964).

68. See, e.g., Mark Osiel, Mass Atrocity, Collective Memory, and the Law 66 (1997) ("Nuremberg should therefore be defended as a political trial, unabashedly so. What mattered most, at such times and places at least, was not to insulate legal institutions from politics, but rather to ensure that they were placed in service of the right kind of politics.")

69. One of the objections, for example, to the Iraqi Special Court set up to try Saddam Hussein and other former lraqi officials is that its all-Iraqi bench may not be seen as impartial. Reynolds Holding, How Hussein is Prosecuted Poses Difficult Choice for Bush; U.S. Leans Toward Trial by Iraqi Panel-Others Prefer International Court, S.F. CHRON., Dec. 15, 2003 at A9. 
forum, many recent examples of transitional trials rely in great measure on international law as the source of substantive law. ${ }^{70}$

The last key component of the Nuremberg model-which distinguishes it not so much from the ignominious historical predecessor of the political show trial, but rather from other modern transitional justice alternatives such as truth commissions-is the focus on individual responsibility. This focus is no doubt driven by the choice of the criminal trial mechanism, but it serves an expressive purpose as well. Even where the crimes of the prior regime were supported by a large percentage of the population, either through their active help or through passive acquicscence, the Nuremberg model fixes liability on key leaders in order to exonerate the rest of the society. As former ICTY Judge Antonio Cassese has explained:

[T]rials establish individual responsibility over collective assignation of guilt, i.e., they establish that not all Germans were responsible for the Holocaust, nor all Turks for the Armenian genocide, nor all Serbs, Muslims, Croats or Hutus but individual perpetrators ... victims are prepared to be reconciled with their erstwhile tormentors, because they know that the latter have now paid for their crimes; a fully reliable record is established of atrocities so that future generations can remember and be made fully cognisant of what happencd. ${ }^{71}$

Individual accountability is thus said to promote peace and reconciliation and reduce the prospect of future violations by breaking the collective cycle of gnilt that frequently fuels conflicts that result in mass atrocity. ${ }^{72}$ The ability of the transitional criminal trial, however, to promotc peace and

70. For example, the convictions of former East German border guards by a unified Germanyoften characterized as an important element of East Germany's transition to democracy-were upheld by German courts using legal principles drawn from international human rights. See Rudolf Geiger, The German Border Guard Cases and International Human Rights, 9 EuR. J. 1NT'L L. 540, 545 (1998) (noting that the Court in the Bundesgerichtshof "emphasized ... that the core of international human rights gives substance and meaning" to the basic principles of human rights implicated in the case). The Statute of the new Special lraqi Tribunal that will try Saddam Hussein also incorporates international crimes. Coalition Provisional Authority, Statute of the Special Iraqi Tribunal, at arts. 1113, http://www.cpa-iraq.org/human_rights/Statute.htm (last visited Aug. 11, 2004).

71. Antonio Cassese, Reflections on International Criminal Justice, 61 MOD. L. REv. 1, 6 (1998).

72. Aryeh Neier, War Crimes: Brutality, Genocide, Terror, and the Struggle for JUSTICE 211 (1998). The transitional justice goal of promoting societal peace and reconciliation is central in the mandates of the ad hoc tribunals for the former Yugoslavia and for Rwanda. The U.N. Security Council created both ad hoc tribunals under its Chapter Vll authority to maintain international peace and security. Secretary General of the U.N., supra note 29, at para. 22 . In creating the ICTY, the Security Council explained that "in the particular circumstances of the former Yugoslavia" it believed that the establishment of an international criminal tribunal "would contribute to the restoration and maintenance of peace." S.C. Res. 827, U.N. SCOR, 48 th Sess., 3217th mtg., at 1-2, U.N. Doc. S/Res/827 (1993). Similarly, the Security Council asserted that the ICTR was designed to "contribute to the process of national reconciliation [in Rwanda] and to the restoration and maintenance of peace." S.C. Res. 955, U.N. SCOR, 49th Sess., 3453rd mtg., U.N. Doc. S/Res/955 (1994). 
reconciliation through the attribution of responsibility to individual defendants depends greatly on the perceived legitimacy of the trial. To the extent that the trial is viewed as illegitimate scapegoating, it may inhibit rather than promote reconciliation.

Compared to other transitional justice mechanisms--especially truth commissions-criminal trials have been characterized as relatively blunt tools for achieving many transitional justice goals. Among other things, in the criminal trial, some are found guilty, and many are implicitly exonerated. In the transitional justice context, some scholars argue that "it is more likely that many people are guilty in different ways and to different degrees." 73 For this reason, critics of transitional trials often posit truth commissions as a preferable alternative to criminal prosecution, although in reality truth commissions have often been employed in tandem with criminal trials rather than in lieu of them..$^{74}$

It is misleading, however, to argue that criminal trials in the transitional context totally eschew the wide-angle lens employed by truth commissions. On the contrary, transitional trials are often used as a mechanism for telling history. As Mark Osiel notes, in transitional trials "the criminal courtroom will inevitably be viewed as providing a forum in which competing historical accounts of recent catastrophes will be promoted ... and judgements likely will be viewed as endorsing one or another version of collective memory." 75 Because of this over-arching historical purpose, transitional trials may include significant testimony on broad historical narrative. Although such evidence bears little relation to the defendant, it is frequently allowed into evidence. ${ }^{76}$ The individual actions of Adolf Eichmann, for example, were widely considered peripheral to his trial, in which Israel sought to provide a comprehensive account of the Holocaust. ${ }^{77}$ Like human rights proceedings, large portions of transitional trials are victim-rather than perpetrator-centered. As Justice Jackson so famously said at Nuremberg, one of the avowed goals of international criminal trials is to create a historical record that establishes the

73. Erin Daly, Transformative Justice: Charting a Path to Reconciliation, 12 INT'L LEGAL PERSP. 73, 154 (2002).

74. In Sierra Leone, for example, international trials and a truth commission procceded simultaneously. Marissa Miraldi, Overcoming Obstacles of Justice: The Special Court of Sierra Leone, 19 N.Y.L. Sch. J. Hum. RTs. 849, 854-55 (2003). Criminal trials followed the truth commissions in Argentina and remained a threat for those not willing to give the truth in exchange for amnesty in South Africa. STEINER \& ALSTON, supra note 66, at 1218-19, 1231-32. A truth commission has likewise been proposed for Bosnia. See International Center for Transitional Justice, ICTJ Activity in Bosnia and Herzegovina, at http://www.ictj.org/europe/bosnia.asp (describing proposal for truth commission in Bosnia).

75. OsIEL, supra note 68 , at 39-40.

76. See, e.g., Prosecutor v. Tadić, Judgement, 1CTY Trial Chamber, at paras. 55-153, Case No. IT-94-1 (May 7, 1997).

77. OsIEL, supra note 68 , at 60 . 
truth for future generations, a record that provides "undeniable proofs of incredible events." 78

This focus on using trials as a vehicle for writing history is controversial, ${ }^{79}$ and it can create a significant tension with the principle of individual eulpability traditionally seen as the foundational principle of liberal criminal proceedings. ${ }^{80}$ Although they formally seek to fix liability on individuals rather than on groups, transitional trials paradoxically may sacrifice the traditional criminal law commitment to individual culpability for the demands of history or narrative. In order to tell a compelling historical story, the prosecution will need to introduce evidence far beyond the defendant's own actions. In theory, such evidence may be relatively unproblematic as a prelude to more specific evidence fixing the defendant's precise place in the overall scheme, and may even be required given that the context may be an element of the crime itself (as with proof that a crime against humanity occurred in the context of a widespread or systematic attack on a civilian population).$^{81}$ In practice, however, given the relatively small number of defendants brought before international criminal fora, once the evidence is in, the temptation is great to hold any given defendant responsible for as wide a swath of destruction as possible.

The political role of the transitional trial also naturally leads to an emphasis on prosecuting high-level perpetrators or "big fish." 82 In the transitional trial, senior leaders come to embody the transgressions of the prior regime, and their guilt serves to exculpate the broader society in which the crimes occurred. The focus on senior leaders is especially pronounced at the international transitional trials. At Nuremberg, for example, only the most senior offenders were brought before the IMT, and lower-level offenders were tried before national military courts in proceedings conducted individually by the Allies. ${ }^{83}$ Similarly, the Security Council has endorsed the official ICTY and ICTR prosecutorial policy that "civilian, military and paramilitary leaders should be tried before them in preference to minor actors." 84 The statute for the Special Court for Sierra Leone, too,

78. International Military Tribunal, Second Day, Wednesday, 21 November 1945, Morning Session, in II Trial of the Major War Criminals Before the InTernational Military Tribunal: Nuremberg, 14 November 1945-1 October 1946, at 95, 99 (I947) (opening statement of Justice Jackson, Chief Prosecutor for the United States).

79. ShKLAR, supra note 67, at 198; Jose E. AIvarez, Rush to Closure: Lessons of the Tadic Judgement, 96 MiCH. L. REv. 2031, 2100-02 (1998).

80. See also OsIEL, supra note 68, at 61. Cf. Prosecutor v. Obrenović, Sentencing Judgement, ICTY Trial Chamber, at para. 52, Case No. 1T-02-60/Z-2 (Dec. 10, 2003) ("One may ask whether the individuals who are called before this Tribunal as accused are simply an instrument through which to achieve the goal of the establishment of the rule of law. The answer is no.").

81. See, e.g., ICTY STATUTE, supra note 9, at art. 5.

82. TEITEL, supra note 57 , at 36.

83. Rt. Hon. The Lord Wright of Durley, Foreward to I UNITED Nations War Crimes Commission, Law Reports of Trials of War Criminals, at viii, ix (1947).

84. S.C. Res. 1329, U.N. SCOR, 4240th mtg., at pmbl., U.N. Doc. S/Res/I329 (2000). 
limits the Court's jurisdiction to those "who bear the greatest responsibility for serious violations of international humanitarian law."

Using criminal trials of political and military leaders as a way to underscore a political transition and to establish democratic principles has a distinctly illiberal corollary. Under such circumstances, the risks of acquittal loom high: ${ }^{86}$ "[w] $[\mathrm{w}$ ] political leaders are acquitted in a criminal proceeding, they choose (unsurprisingly) to interpret this legal result as a complete vindication of their story." ${ }^{\text {"87 }}$ As further explored in Part IV, the emphases of the transitional trial on the articulation of historical narrative and the conviction of former leaders for direct involvement in the atrocities of the period have exerted a significant, and sometimes deleterious, effect on the development of the liability theories of international criminal law.

\section{II \\ InTERnational Criminal Law at THE Crossroads: ESTABLISHING LEGITIMACY}

Before turning to the substantive doctrines we explore in this Article, we pause to consider the appropriate balance which international criminal judges should strike among the criminal law, human rights, and transitional justice elements of their jurisprudence. Although international criminal law has matured rapidly over the past ten years, it still suffers from questions about its legitimacy. Both the lack of democratic accountability and the significant amount of prosecutorial and judicial discretion inherent in the international criminal system compound this problem. In this section, we argue that these features of international criminal law suggest that judges should hew closely to the restraining influences of the culpability model when deciding how to construe substantive and procedural rules.

Unlike most domestic criminal law systems, international criminal law is not embedded in a mature political or legal system that lends legitimacy to its criminal process. Although international humanitarian law, the direct doctrinal predecessor of international criminal law, is a longstanding body of law, contemporary enforcement of international criminal law began only with the establishment of the ICTY and the ICTR. These tribunals remain controversial, and the newly-established-and more ambitious-

85. United Nations, Agreement Between the United Nations and the Government of Sierra Leone on the Establishment of a Special Court for Sierra Leone, at art. 1, U.N. Doc. S/2002/246, appendix II (2000), available at http:/www.sc-sl.org/scsl-agreement.html.

86. See, e.g., Richard P. Barrett \& Laura E. Little, Lessons of Yugoslav Rape Trials: A Role for Conspiracy Law in International Tribunals, 88 MINN. L. REv. 30, 32 (2003) (arguing that "[a]cquittals of important figures 'impair the inhibitory effect of international justice on those whom it is most important to deter'”').

87. OsIEL, supra note 68, at 105; see also Nedim Dervisbegovic, Croat Not Welcome, Muslim Villagers Say; Survivors of a 1993 Massacre in Busnia Reject a War Criminal's Visit, HoustoN Chron., Aug. 6, 2004, at 31 (describing polarized reactions to ICTY Appeals Chamber decision reversing conviction of General Tihomir Blaškić). 
International Criminal Court has elicited even more criticism. Moreover, because of its focus on individuals and its enforcement through terms of imprisonment, international criminal law differs significantly from the rest of international law.

At this point in the development of the field, establishing the legitimacy of international criminal proceedings poses the most critical challenge for international tribunals. Legitimacy is the sine qua non for achieving not only the criminal law objectives, but also the human rights and transitional justice ambitions of the field. Human rights law relies on the notion that the authoritative enunciation of norms will help reconstitute national interests so that, over time, compliance increases even without a realistic threat of direct sanctions. ${ }^{88}$ Legitimacy is also important to transitional justice aims of international criminal law, insofar as proceedings perceived as illegitimate are not likely to foster peace and reconciliation.

Preserving the criminal law paradigm, and in particular, the culpability principle as its cornerstone provides the key to establishing legitimacy in international criminal law. Alone among the three influences we have described, the criminal law paradigm contains the potential to provide a brake on over-expansive doctrinal interpretations. Limitations derived from criminal principles preserve not only the rights of the defendants, but also the legitimacy of the proceedings in a way that is critical to serving their transitional justice and human rights goals.

The recent rapid expansion of international criminal law has proven its vitality but not its maturity. At present, international criminal law deprives individuals of their liberty in proceedings that have an inescapable aura of arbitrariness about them-no matter how carefully protected the defendants' right to fair process. The number of offenses that qualify as international crimes and the limited capacity of international courts to adjudicate cases provide the prosecutions that do go forward with an unavoidable element of selectivity, at least for those defendants not forming part of the senior political or military leadership. Even for senior leaders, the limited capacity of international courts leads to a certain arbitrariness: an observer might ask, for example, why Milošević is on trial, when so many other heads of state who have committed equal or greater crimes are not. ${ }^{89}$ While this aspect of international criminal proceedings does not fatally undermine their legitimacy, since a new enterprise of law enforcement must begin somewhere, it does create a greater need for caution in the application of the law to the few individuals brought before them.

88. Thomas M. Franck, The Power of Legitimacy Among Nations 16 (1990); Harold Hongju Koh, How is International Human Rights Law Enforced?, 74 IND. L.J. 1397, 1410 (1999).

89. See Mark A. Drumbl, Collective Violence and Individual Punishment: The Criminality of Mass Atrocity, 99 Nw. U. L. REv. (forthcoming 2005), available at http://ssm.com/abstract=530182 (observing that "only some radical evil gets punished, whereas much escapes its grasp ... criminal law always is contingent on politics"). 
Furthermore, much of international criminal law is developed through customary international law in which, by definition, there is no central legislative organ. Even where there is an oversight body attached to a particular international criminal institution, it seems unlikely that it will take an aggressive role toward altering judicial elaboration of the crimes or liability theories within the institution's jurisdiction. Ten years into the ad hoc Tribunals' work, the Security Council, for example, has not amended any of the definitions of the substantive crimes or liability theories in the Statutes of the ICTY or ICTR.

In international criminal proceedings, each defendant faces a legal system whose crimes and procedures are largely foreign to him and are themselves undergoing rapid development. International criminal law includes the most serious consequence of domestic criminal proceedingsnamely the right to deprive individuals of their liberty-but inherently lacks the security provided by a clearly-articulated and time-tested criminal code, familiar and longstanding criminal procedures, and the certainty that most serious crimes will be punished. Although many domestic criminal systems may have in practice significantly relaxed the requirements that stem from the principles of culpability that underlie their own criminal systems, ${ }^{90}$ we believe that international criminal law cannot yet afford to follow a similar path.

The doctrines explored in Parts III and IV of this Article, and particularly joint criminal enterprise, provide significant discretion to international prosecutors to determine the scope of wrongdoing that will be attributed to any single defendant. Joint criminal enterprise, in theory, allows for all crimes committed against a particular group within an entire region over a period of years to be attributed to a defendant if he was part of a group that intended to perpetrate these crimes. The breadth of the international prosecutor's discretion is not unique to international criminal law, but the importance of the institutional locus of power in international criminal systems is magnified because of the type of crimes implicated by international criminal law.

International crimes are typically committed by hundreds, sometimes thousands, of people. ${ }^{91}$ The Rwandan genocide, for example, has been estimated to involve thousands of perpetrators: in 1997, over 92,000 genocide suspects were locked up in Rwandan jails. ${ }^{92}$ Given the capacity

90. See, for example, the discussion of RICO in U.S. law, infra text accompanying notes 293302.

91. E. van Sliedregt, The Criminal Responsibility of Individuals for Violations of INTERNATIONAL HUMANITARIAN LAW 4-5 (2003) (describing violations of international criminal law as involving "system-criminality").

92. Alan Zarembo, Judgement Day, HaRPER's MAG., Apr. 1997, at 68. Other sources give the number of alleged perpetrators imprisoned in Rwanda at this time as 120,000 E.g., The Rwandan Tribunal and Its Relationship to Rwanda, 13 AM. U. INT'L L. REv. 1469, 1474 (1998). 
limitations of international courts, international prosecutors have significant discretion to determine which individuals to charge with crimes. ${ }^{93}$ The importance of prosecutorial discretion is further compounded by the evolving definitions of international crimes. While there is significantly more jurisprudence on the elements of international crimes today than there was in the early 1990s, significant questions remain unresolved. Several of the provisions of the ICTY and ICTR statutes have not yet been construed by the ICTY and ICTR judiciaries. ${ }^{94}$ The Rome Statute of the International Criminal Court (ICC) is far more complex than the ICTY and ICTR statutes and its application will present difficult, and novel, questions of legal interpretation.

In addition, many of the definitions of the crimes themselves call for exercise of prosecutorial judgement. One of the war crimes proscribed under the ICC Statute, for example, is "[i]ntentionally launching an attack in the knowledge that such attack will cause incidental loss of life or injury to civilians or damage to civilian objects... which would be clearly excessive in relation to the concrete and direct overall military advantage anticipated." 95 While this crime clearly forms part of customary international humanitarian law, its application in individual cases can be highly controversial. It is up to international prosecutors, in the first instance, to decide what kinds of civilian harm are "clearly excessive."

Furthermore, international crimes do not have specific sentencing ranges attached to them. International judges may impose any sentence from one day imprisonment to life imprisonment for every crime within the jurisdiction of the ICTY and ICTR. ${ }^{96}$ Although the judges remain free to determine their own sentences, they may rely heavily on the prosecution's suggestion of appropriate sentences in individual cases. The recent surge in plea bargaining at the ICTY, ${ }^{97}$ while not bearing an obvious link to the use

93. For a discussion of prosecutorial discretion in the context of the ICC, see Allison Marston Danner, Enhancing the Legitimacy and Accountability of Prosecutorial Discretion at the International Criminal Court, 97 AM. J. INT'L L. 5I0, 518-22 (2003).

94. The ICTY, for example, has not defined the elements of the crimes of Willfully Depriving POWs or Civilians of the Rights of Fair and Regular Trials or using Biological Experiments as a Form of Inhuman Treatment. ICTY STATUTE, supra note 9, at art. 2(b) (biological experiments), art. 2(f) (fair trial); John R. W. D. Jones \& Steven Powles, International Criminal Practice 248-49 (3rd ed. 2003).

95. ICC STATUTE, supra note 9, at art. 8(2)(b)(iv).

96. See generally Allison Marston Danner, Constructing a Hierarchy of Crimes in International Criminal Law Sentencing, 87 VA. L. Rev. 415 (2001). The ICC Statute, however, limits sentences either to a maximum of thirty years or to "life imprisonment when justified by the extreme gravity of the crime and the individual circumstances of the convicted person." ICC STATUTE, supra note 9, at art. $77(1)(b)$.

97. See Marlise Simons, Plea Deals Being Used to Clear Balkan War Tribunal's Docket, N.Y. Times, Nov. 18, 2003, at A1. 
of joint criminal enterprise, ${ }^{98}$ also provides evidence of the importance of prosecutorial discretion in the administration of international criminal law.

Because of the wide discretion granted to international prosecutors in a variety of areas, because of the novelty of the international forum, because of the political nature of many of the prosecutions, and because of the lack of international consensus about the meaning of some of the crimes in international criminal law, it is especially important that international criminal judges protect defendants through careful attention to the culpability principle and similar doctrines that seek to ensure that defendants are convicted for their own conduct and not merely for the violent trauma experienced by entire nations.

The human rights and transitional justice paradigms quite correctly inform the goals of international criminal law. But over-reliance on interpretive techniques drawn from the human rights paradigm or on the less praiseworthy strands of the transitional trial tradition may pose a threat to the legitimacy of international criminal law. Because human rights law's focus has traditionally been on state responsibility and not on pinpointing responsibility for individual violations, it can allow for the imposition of liability on a state in situations where imposition of criminal liability on an individual might violate the culpability principle. As a general matter, civil liability is often (and purposefully) easier to obtain than criminal liability. ln addition to requiring a lower standard of proof (preponderance of the evidence as opposed to beyond a reasonable doubt), civil tort law is more tolerant of vicarious liability and imputed responsibility than is criminal

98. The evolving use of plea bargaining at the ICTY is a fascinating topic in its own right that is beyond the scope of this Article. It does not appear, however, that joint criminal enterprise (JCE) plays a major role in plea bargaining. The defendants that have recently pleaded guilty have, on the whole, plcaded to charges like persecution that capture the entirety of the wrongdoing of which they are accused in a single, umbrella charge. See, e.g., Prosecutor v. Nikolić, Sentencing Judgement, ICTY Trial Chamber, at para. 51, Case No. IT-02-60/I-S (Dec. 2, 2003) (noting that "while the Prosecution moved to dismiss numerous charges against Momir Nikolić, including genocide, it did not seek to remove any of the factual allegations underlying these crimes. Thus, the factual basis upon which the remaining charge of persecutions is based can be found to reflect the totality of Momir Nikolić's criminal conduct"). Some defendants have recently pleaded guilty to a single count of perseeution. See, e.g., Prosecutor v. Deronjić, Sentencing Judgement, ICTY Trial Chamber, Case No. IT-02-61-S (Mar. 30, 2004); Prosecutor v. Obrenović, Sentencing Judgement, ICTY Trial Chamber, supra note 80; Prosecutor v. Banović, Sentencing Judgement, ICTY Trial Chamber, Case No. IT-0I-65/1-S (Oct. 28, 2003); Prosecutor v. Plavšić, Sentencing Judgement, ICTY Trial Chamber, Case No. IT-00-39\&40/I (Feb. 27, 2003). Other defendants have recently pleaded guilty to all counts with which they were charged. See, e.g., Prosecutor v. Ćešić, Plea Agreement, Case No. IT-95-10/1-PT (Oct. 8, 2003); Prosecutor v. Jokić, Second Amended Indictmont, Case No. IT-01-42/1 (Aug. 27, 2003). These facts suggest that reducing the alleged scope of potential liability through the mechanism of charge bargaining, wbich pIays an important role in U.S. criminal practice (and in the use of conspiracy charges by prosecutors, see Neal Kumar Katyal, Conspiracy Theory, 112 YALE L.J. 1307, 1328, 1338 (2003)), does not play an important role in international criminal practice. Since JCE is a method for increasing the defendant's potential exposure to criminal liability, the fact that charge bargaining does not oecur suggests that the simultaneous rise of JCE and plea bargaining at the ICTY are not closely linked. 
law. These distinctions reflect the different purposes of criminal and civil tort liability: tort liability focuses more heavily on compensation for victims as well as deterrence of wrongdoing. Indeed, the balance of influences may point in a different direction when the mix of concerns from the human rights and the transitional justice models are set off against the civil tort model, as opposed to the criminal model. In the civil context, the balance may often point towards more expansive liability.

Importing the interpretive techniques and analytical modes drawn from a human rights paradigm, which is based on ensuring that all serious harms to human life and well-being find protection within its ambit, to a system designed to punish individuals for transgressions of previouslyarticulated crimes, poses clear dangers for the integrity of a criminal law system. Paradoxically, it also risks weakening the human rights of the defendants, which might receive more serious attention in a forum explicitly devoted to human rights. And to the extent that human rights law relies in large part on the persuasive force of norms, anything that undermines the legitimacy of proceedings in which such norms are enunciated is likely to reduce the overall effectiveness of the norm. In other words, the benefit to human rights from an overly expansive approach is illusory. The less laudable strands of transitional justice trial tradition also give reason for caution. While attribution of blame to particular individuals may help society move on by countering notions of collective or group guilt, there is also an ever-present danger of scapegoating that can undermine the whole enterprise.

We emphasize that we do not suggest that international criminal courts should ignore the human rights and transitional justice goals of international criminal law. Rather we believe that all three goals need to be balanced on a case-by-case basis, and that the balance tips in favor of close adherence to the criminal culpability model in the context of construing liability doctrines. However, there are other areas in which international tribunals could profitably pay greater attention to the human rights and transitional justice aspects of their mission. For example, we believe that, compared to national criminal courts, international criminal tribunals will often need to place greater emphasis on victim and witness support programs, as well as public education and outreach efforts. Full exploration of these other areas of tribunal practice is beyond the scope of this Article; we simply provide these examples here as a caveat, lest our argument in favor of emphasizing the criminal law culpability model in certain doctrinal areas be perceived as an argument against the importance of human rights and transitional justice goals more generally. We also stress that ours is not an argument against accountability; it is an argument for accountability with care and precision in its scope. Proper calibration of individual 
responsibility is essential to ensuring that the commendable, rather than the troublesome, aspects of the transitional justice tradition are implemented.

The liability theories of international criminal law function as the central doctrinal device through which these normative questions relating to the proper attribution of responsibility, guilt, and wrongdoing are mediated. The following Part examines the two most complex and far-reaching liability theories used in international criminal law: joint criminal enterprise and command responsibility.

\section{III}

JOINT CRIMINAL ENTERPRISE AND COMMAND RESPONSIBILITY: DOCTRINE AND HISTORY

International criminal prosecutors enjoy an array of liability theories with which to accuse an individual of having committed an international crime. Article 7(1) of the ICTY Statute and Article 6(1) of the ICTR statute describe the five forms of "direct responsibility" in identical terms: "A person who planned, instigated, ordered, committed or otherwise aided and abetted in the planning, preparation or execution of a crime ... shall be individually responsible for the crime." $100 \mathrm{On}$ its face, this provision encompasses five kinds of liability: two principal and three accessorial. A defendant can be found guilty as a principal if he "committed" a crime. He may also be liable if he "planned" a crime, whether by himself or with others. Under either of these provisions, the defendant must either intend to plan or intend to commit the crime or be "aware[] of the substantial likelihood that a criminal act or omission would occur as a consequence of his conduct."101

An individual can also be liable for a crime based on his interaction with others: he can instigate, order, or aid and abet the commission of a crime by another. These forms of liability are accessorial in that they rely on someone other than the defendant to commit a crime and thus incur liability both to the principal (the person physically committing the crime) and to the accessory (the defendant). ${ }^{102}$

The command responsibility provisions of the ICTY and ICTR statutes, Articles 7(3) and 6(3) respectively, provide for another form of

99. In the jurisprudence of the Tribunals, these five forms of liability are usually referred to as "direct responsibility," to distinguish them from command responsibility (or "superior responsibility"). See, e.g., Prosecutor v. Mucić, Judgement on Sentence Appeal, ICTY Appeals Chamber, at para. 34, Case No. IT-96-2I-Abis (Apr. 8, 2003) (contrasting "direct" responsibility with "superior" responsibility); Prosecutor v. Delalić, Judgement, ICTY Trial Chamber, supra note 30, at para. 12 .

100. ICTR STATUTE, supra note 9, at art. 6(1); ICTY STATUTE, supra note 9, at art. 7(I).

101. Prosecutor v. Kvocka, Judgement, ICTY Trial Chamber, at para. 251, Case No. 1T-98-30/1-T (Nov. 2, 2001) [hereinafter Kvočka Trial Judgement].

102. See Prosecutor v. Kordić, Judgement, ICTY Trial Chamber, at para. 373, Case No. IT-9514/2-T (Feb. 26, 2001) (noting "[ $t$ ] he various forms of participation listed in Article $7(1)$ may be divided between principal perpetrators and accomplices"). 
accessorial liability, namely that a person possessing command authority, whether as a civilian or military leader, may also be responsible for crimes committed by his subordinates if the leader fails to prevent the crimes or fails to punish the crimes once they occur.

The fact that any of the acts ... was committed by a subordinate does not relieve his superior of criminal responsibility if he knew or had reason to know that the subordinate was about to commit such acts or had done so and the superior failed to take the necessary and reasonable measures to prevent such acts or to punish the perpetrators thereof. ${ }^{103}$

The form of liability known as "joint criminal enterprise" or "common plan" is not explicitly described in the statute of the ICTY or ICTR, although the judges have found that it is implicitly included in the language of Article 7(1) of the ICTY Statute. Under this form of liability, an individual may be held responsible for all crimes committed pursuant to the existence of a common plan or design which involves the commission of a crime provided for in the Statute if the defendant participates with others in the common design. ${ }^{104}$ The crime of genocide also contains its own liability provision. ${ }^{105}$

\section{A. The Development of Joint Criminal Enterprise}

Ironically, the most complex and conceptually challenging liability theory in international criminal law is the only one not mentioned explicitly in the statutes of the ICTY or ICTR. Joint criminal enterprise (which is also referred to by a variety of other terms, including "common purpose" and "common plan" liability) ${ }^{106}$ has largely been created by the judges and

103. 1CTY STATUTE, supra note 9, at art. 7(3); see also ICTR STATUTE, supra note 9, at art. 6(3).

104. Prosecutor v. Vasiljević, Judgement, ICTY Appeals Chamber, at paras. 94-101, Case No. IT98-32-A (Feb. 25, 2004) (summarizing JCE jurisprudence). The Appeals Chamber has stated that "in relation to a particular count, it is not appropriate to convict under both Article 7(1) and Article 7(3) of the Statute." Prosecutor v. Blaškić, Judgement, 1CTY Appeals Chamber, at para. 91, Case No. IT-9514-A (July 29, 2004) [hcreinafter Blaškić Appeals Judgement]. If the prosecution has alleged direct and command responsibility in the same count, the Trial Chambcr should enter a conviction under $7(1)$ and consider the defendant's position of authority as an aggravating factor in sentencing. Id.

105. Article 4(3)(e) of the ICTY Statute and Article 2(3)(e) of the ICTR Statute (like Article 111 of the Genocide Convention) criminalize "complicity in genocide." See van SLIEDREGT, supra note 91, at 32-33. The exact relationship between these provisions and the forms of liability listed in the general liability provisions in the ICTY and 1CTR Statutes is somewhat unclear. See Prosecutor v. Krstic, 1CTY Appeals Chamber, at paras. 138-40, Case No. 1T-98-33-A (Apr. 19, 2004) [hereinafter Krstić Appeals Judgement] (discussing relationship between provisions). We will not discuss it further in this Article.

106. The Tadic court referred to this doctrine by a variety of names and used the various descriptions interchangeably. 1t referenced, for example, "common criminal plan," "common criminal purpose," "common design or purpose," "common criminal design," "common purpose," "common design," "common concerted design," "criminal enterprise," "common enterprise," and "joint criminal enterprise." Prosecutor v. Brdjanin, Decision on Form of Further Amended Indictment and Prosecution Application to Amend, ICTY Trial Chamber, at para. 24, Case No. 1T-99-36 (June 26, 2001), available at 2001 WL 1793829 (describing the Tadić Judgement). In addition, the Office of the Prosecutor [OTP] 
prosecutors of the Yugoslav Tribunal. Its prominence at the ICTY dates from the case of Dusko Tadić, the first full trial heard by the Tribunal.

\section{The Tadic Decision: The 1CTY Embraces Joint Criminal Enterprise}

The context of Tadic helps explain the early development of joint criminal enterprise. Tadić was an enthusiastic but relatively low-level participant in the crimes that occurred in Bosnia in the early 1990s, and he was available for trial at the ICTY at a time when it suffered from both a lack of individuals to try and a surfeit of judges with no cases to adjudicate. In 1995, Tadić was indicted by the ICTY Prosecutor on a variety of charges. At his trial, he was convicted of several counts of war crimes and crimes against humanity but was acquitted of one of the most serious chargesmurder as a crime against humanity-for the murder of five Muslim men in the Bosnian village of Jaskići. ${ }^{107}$ The Trial Chamber found that Tadic was a member of a group of armed men who entered Jaskići and beat its inhabitants. Furthermore, the Trial Chamber noted that the five victims, who were alive when the armed group entered the town, were found shot to death after the group's departure. Nevertheless, the Trial Chamber determined that it could not "on the evidence before it, be satisfied beyond reasonable doubt that the accused had any part in the killing of the five men." 108 It also found that the deaths occurred at the same time as a larger force of Serb soldiers was involved in an ethnic cleansing operation in a neighboring village. ${ }^{109}$

The prosecution appealed Tadić's acquittal of this charge, arguing that the Trial Chamber had misapplied the test of proof beyond reasonable doubt." The Appeals Chamber agreed, concluding that "the only reasonable conclusion the Trial Chamber could have drawn is that the armed group to which [Tadić] belonged killed the five men." Appeals Chamber next considered whether Tadic could be found guilty of the killing, despite an absence of proof that he had personally shot the men.

of the ICTY has used the phrase "acting in concert" in its indictments to refer to joint criminal enterprise. Prosecutor v. Vasiljević, Judgement, ICTY Trial Chamber, supra note 32, at para. 63. The ICTY Appeals Chamber has said that the phrase "joint criminal enterprise is preferred." Prosecutor v. Multinović, Decision on Dragoljub Ojdanić's Motion Challenging Jurisdiction-Joint Criminal Enterprise, 1CTY Appeals Chamber, at para. 36, Case No. IT-99-37-AR72 (May 21, 2003). We primarily employ this designation in this Article.

107. Tadić was, however, convicted of killing of two Muslim policemen in the town of Kozarac. Prosecutor v. Tadić, Sentencing Judgement, ICTY Trial Chamber, at para. 57, Case No. IT-94-1-T (July 14, 1997).

108. Prosecutor v. Tadić, Judgement, ICTY Trial Chamber, at para. 373, Case No. IT-94-1-T (May 7, 1997).

109. Id.

110. Drawing from the civil law tradition, international criminal law provides the prosecution with the right to appeal an acquittal.

111. Prosecutor v. Tadić, Judgement, ICTY Appeals Chamber, at para. 183, Case No. IT-94-1-A (July 15, 1999) [hereinafter Tadić V]. 
The Appeals Chamber first reviewed the language of Article 7(1). While it noted that the forms of liability articulated therein described "first and foremost the physical perpetration of a crime by the offender himself," it also found that the crimes within the jurisdiction of the Tribunal "might also occur through participation in the realisation of a common design or purpose." 112 To determine the relevant requirements for common purpose liability, the Tadic Appeals Chamber turned to customary international law, which it derived chiefly from case law of military courts set up in the wake of World War II. The Appeals Chamber identified several cases from this period in which it found that military courts had convicted individuals on the basis of participating in a common plan. Although, as examined later in this Part, the Appeals Chamber's legal analysis of these cases is problematic, the court based its now-canonical description of JCE on its gloss of these earlier cases.

After reviewing this jurisprudence, the Appeals Chamber concluded that "broadly speaking, the notion of common purpose encompasses three distinct categories of collective criminality." 113 In the first category, the perpetrators act pursuant to a common design and share the same criminal intention. ${ }^{114}$ The Appeals Chamber has, in later cases, restated the common design element as requiring that the defendants have entered into an agreement with other members of the joint criminal enterprise (JCE) to commit crimes. ${ }^{15}$ To be found guilty of the crime of murder via this "Category One" of JCE, for example, the prosecution must prove that the common plan was to kill the victim, that the defendant voluntarily participated in at least one aspect of this common design, and that the defendant intended to assist in the commission of murder, even if he did not himself perpetrate the killing. ${ }^{116}$

The second category of JCE relates to "systems of ill-treatment," primarily concentration camps. ${ }^{117}$ For this category, the prosecution need not prove a formal or informal agreement among the participants, but must demonstrate their adherence to a system of repression. ${ }^{118}$ To convict an individual under this rubric, the prosecution must prove the existence of an organized system of repression; active participation in the enforcement of this system of repression by the accused; knowledge of the nature of the system by the accused; and the accused's intent to further the system of

112. Id. at para. 188 .

113. Id. at para. 195 .

114. Id. at para. 196.

115. Prosecutor v. Multinović, Decision on Dragoljub Ojdanić's Motion Challenging Jurisdiction-Joint Criminal Enterprise, ICTY Appeals Chamber, at para. 23, Case No. IT-99-37AR72 (May 21, 2003).

116. Tadić V, supra note 111 , at para. 196.

117. See id. at para. 202.

118. Prosecutor v. Kmojelac, Judgement, ICTY Appeals Chamber, at para. 96, Case No. IT-9725-A (Sept. 17, 2003). 
repression. ${ }^{119}$ In both Categories One and Two, all members of the JCE may be found criminally responsible for all crimes committed that fall within the common design. ${ }^{120}$

The third, and most far-reaching, category of JCE involves criminal acts that fall outside the common design. The Tadić Appeals Chamber concluded that a defendant who intends to participate in a common design may be found guilty of acts outside that design if such acts are a "natural and foreseeable consequence of the effecting of that common purpose."'21 The Appeals Chamber did not clearly specify whether the foreseeability component of this category should be assessed objectively or subjectively, ${ }^{122}$ although, given the difficulty of proving subjective foreseeability, the distinction arguably has little practical importance. ${ }^{123}$

As an example of the kind of act that would fall within this third category, the Appeals Chamber offered the illustration of

a common, shared intention on the part of a group to forcibly remove members of one ethnicity from their town, village or region ... with the consequence that, in the course of doing so, one or more of the victims is shot and killed. While murder may not have been explicitly acknowledged to be part of the common design, it was nevertheless foreseeable that the forcible removal of civilians at gunpoint might well result in the deaths of one or more of these civilians. ${ }^{124}$

The Appeals Chamber also noted that all participants in the common enterprise would be guilty of this murder if the risk of death was a "predictable consequence of the execution of the common design" and if they were "reckless or indifferent" to that risk. ${ }^{25}$

The Appeals Chamber's third scenario is, in fact, a restatement of the facts in Tadić's case surrounding the killings in Jaskići. After tipping its hand through this doctrinal exegesis, the Appeals Chamber found that Tadic had participated in the common "criminal purpose to rid the Prijedor region of the non-Serb population." 26 The Appeals Chamber also found

119. Id. at para. 203.

120. With the exception of attempt to commit genocide, there is no crime of attempt within the ICTY or 1CTR Statutes. The 1CC Statute does criminalize attempt. ICC STATUTE, supra note 9, at art. 25(3)(f).

121. Tadić V, supra note 111 , at para. 204.

122. The Appeals Chamber used somewhat contradictory language about the foreseeability inquiry. It stated that the defendant, "although he did not intend to bring about a certain result, was aware that the actions of the group were most likely to lead to that result but nevertheless willingly took that risk," but the Chamber also noted that "everyone in the group must have been able to predict this result." Id. at para. 220.

123. See Note, Developments in the Law, Criminal Conspiracy, 72 Harv. L. Rev. 922, 996 (1959) (making this point in the context of liability for conspiracy).

124. Tadić V, supra note 111 , at para. 204.

125. Id.

126. Id. at para. 232. 
both that the killing of non-Serbs was foreseeable in light of this purpose and that Tadic was aware of this risk but nevertheless willingly participated in the common plan. ${ }^{127}$ On appeal, therefore, Tadic found himself convicted of the murder of the five men on the liability theory of a Category Three JCE-a crime for which he had been acquitted at trial. His sentence was ultimately raised from twenty to twenty-five years. ${ }^{128}$

Joint criminal enterprise is becoming increasingly important at the ICTY. One indication of its centrality to contemporary ICTY practice is the frequency with which recent indictments have rested the accused's liability on this basis. ${ }^{129}$ The first indictment to rely explicitly on JCE was confirmed on June 25, 2001-eight years into the ICTY's work. ${ }^{130}$ Of the forty-two indictments filed between that date and January I, 2004, ${ }^{131}$ twenty-seven (64\%) rely explicitly on JCE. Furthermore, as we discuss in the context of transitional trials, JCE is now used by international prosecutors as the method of choice for targeting senior military and political leaders. Slobodan Milošević, for example, stands accused of participating in three massive JCEs. ${ }^{132}$

127. Id.

128. Prosecutor v. Tadić, Sentencing Judgement, ICTY Trial Chamber, at para. 32, Case No. IT94-I-Tbis-RI17 (Nov. 11, 1999). After further proceedings, however, Tadić's sentence was reduced to twenty years. Prosecutor v. Tadić, Judgement in Sentencing Appeals, ICTY Appeals Chamber, at para. 76(3), Case Nos. IT-94-1-A \& IT-94-1-Abis (Jan. 26, 2000).

129. Kelly D. Askin, Reflections on Some of the Most Significant Achievements of the ICTY, 37 NEw ENG. L. REv. 903, 910-11 (2003) ("In the last two years, it appears that participating in a joint criminal enterprise has become the principal charging preference in ICTY indictments").

130. Tadić's indictment did not explicitly refer to joint criminal enterprise, common purpose liability, or any of its synonyms. See Prosecutor v. Tadić, Second Amended Indictment, Case No. IT94-1-I (Dec. 14, 1995).

131. Calculating the total number of indictments filed at the ICTY is complicated by the fact that the prosecution routinely files amended indictments in each case. In our calculations, we have counted only the latest amended indictment in each case. In addition, if several accuscd were initially joined together in one indictment, but then went to trial separately, we counted each indictment separately.

132. Prosecutor v. Milošević, Initial Indictment, at para. 6, Case No. IT-0I-5 I-I (Nov. 22, 2001) (alleging that Milošević participated in a joint criminal enterprise, whose purpose "was the forcible and permanent removal of the majority of non-Serbs, principally Bosnian Muslims and Bosnian Croats, from large areas of the Republic of Bosnia and Herzegovina"). This indictment also states that "[b]y using the word 'committed' in this indictment, the Prosecutor does not intend to suggest that the accused physically committed any of the crimes charged personally. 'Committed' in this indictment refers to participation in a joint criminal enterprise as a co-perpetrator." Id. at para. 5. See also Prosecutor v. Milošević, First Amended Indictment, at para. 6, Case No. IT-02-54-T (Oct. 23, 2002) (alleging that Milošević participated in a joint criminal enterprise, whose purpose "was the forcible removal of the majority of the Croat and other non-Serb population from the approximately one-third of the territory of the Republic of Croatia that he planned to become part of a new Serb-dominated state"); Prosecutor v. Milošević, Second Amended Indictment, at para. 16, Case No. IT-99-37-PT (Oct. 29, 2001) (alleging that Milošević participated in a joint criminal enterprise as a co-perpetrator whose purpose "was, inter alia, the expulsion of a substantial portion of the Kosovo Albanian population from the territory of the province of Kosovo in an effort to ensure continued Serbian control over the province"). 
Moreover, the number of indictments explicitly referring to JCE understates the significance of the doctrine since, prior to July 2004, Trial Chambers had ruled that a defendant could be convicted on a JCE theory even if his indictment did not explicitly refer to $\mathrm{JCE},{ }^{133}$ and that phrases like acting "in concert" may be read as implicit references to JCE theory. ${ }^{134}$ If all indictments that include charges that the defendant acted "in concert" with others are viewed as implicitly employing a JCE theory, then thirtyfour of the forty-three indictments confirmed between June 25, 2001 and January 1, 2004 ( $81 \%$ of the total) incorporate JCE.

The decision by the ICTY Appeals Chamber to read this wide-ranging form of liability into the Statute has been controversial. The answers to important doctrinal questions remain uncertain. Most of the unresolved controversies go to the peripheries of JCE: whether even a de minimis contribution to a JCE suffices to place an individual within the criminal enterprise, and whether there are any limits on the prosecution's discretion to define the scope of the enterprise. Since any member of a JCE may be found guilty of any crime committed within the scope of the JCE (in Categories One and Two) and any foreseeable crime outside the scope of the JCE (in Category Three), the answers to these questions are of considerable praetical importance.

The most far-reaching aspect of JCE involves what the ICTY labels "Category Three," or "extended" JCEs. If the prosecution successfully demonstrates that the defendant intended to participate in a JCE, that defendant will be liable for crimes committed by others that he did not intend, as long as those crimes were foreseeable. Category Three JCEs, therefore, lower the relevant mental state from intention or knowledge to recklessness. Although JCE is not widely used at the ICTR, ${ }^{135}$ at least one

133. See Prosecutor v. Krstić, Judgement, ICTY Trial Chamber, at para 602, Case No. IT-98-33-T (Aug. 2, 2001); Kvočka Trial Judgement, supra note 101, at para. 246. In the Blaškić Judgement, handed down July 29, 2004, the Appeals Chamber clarified that "the alleged form of participation of the accused in a crime pursuant to Article 7(1) of the Statute should be clearly laid out in an indictment." Blaškić Appeals Judgement, supra note 104, at para. 215.

134. See Proseeutor v. Simić, Judgement, ICTY Trial Chamber, at para. 149, Case No. 1T-95-9-T (Oct. 17, 2003) ("It is commonly accepted that a reference to 'acting in eoneert together' means aeting pursuant to a joint criminal enterprise."); Prosecutor v. Vasiljević, Judgement, ICTY Trial Chamber, supra note 32 , at para. 63 .

135. Based upon the ICTY's JCE jurisprudence, the 1CTR Appeals Chamber has found that JCE may also be used at the ICTR. Prosecutor v. Ntakirutimana, Judgement, ICTR Appeals Chamber at para. 468, Case No. ICTR-96-10-A (Dec. 13, 2004). The relative lack of JCE-related jurisprudence at the ICTR is likely due to a variety of factors. First, conspiracy to commit genoeide is included within the ICTR Statute and has been frequently alleged by the proseeution, thus removing much of the need for recourse to JCE. See, e.g., Prosecutor v. Musabyimana, ICTR Indictment, at paras. 35-39, Case No. ICTR-2001-62-1 (Mar. 15, 2001); Prosecutor v. Kamuhanda, ICTR Indictment, at 1, Case No. ICTR99-54-A (Nov. 15 2000); Prosecutor v. Bisengimana, 1CTR Indictment, at 1, Case No. 1CTR-2000-60-I (July 10, 2000); Prosecutor v. Rugambarara, ICTR Indictment, at 1, Case No. ICTR-2000-59 (July 10, 2000); Prosecutor v. Bizimungu, ICTR Indictment, at 1, Case No. 1CTR-99-50-1 (May 10, I999). Furthermore, several 1CTR indictments do rely in part on JCE principles. See, e.g., Prosecutor v. 
ICTR Trial Chamber has suggested that the accused may be responsible for crimes that were objectively foreseeable, even if he did not himself foresee them-effectively lowering the mental state still further to negligence. ${ }^{136}$

Category Three of JCE is particularly controversial because many national systems do not recognize the liability of participants in a common plan for crimes that fall outside the scope of the common objective. ${ }^{137}$ Germany, the Netherlands, and Switzerland, for example, do not include this form of liability in their criminal codes. ${ }^{138}$ Even in countries like Britain and Canada that do recognize liability for foreseeable crimes in this situation, the doctrine is subject to significant criticism because it effectively lowers the mens rea required for commission of the principal crime without affording any formal diminution in the sentence imposed. ${ }^{139}$

In the Tadic decision, the ICTY Appeals Chamber largely did not address the objections to this extended form of complicity. Instead, it called upon World War II-era cases to justify the doctrine's existence as a matter of customary international law and to elucidate its elements. In addition, the Appeals Chamber has subsequently rejected arguments that joint criminal enterprise amounts either to conspiracy or to organizational liability, both of which were extensively used at the International Military Tribunal at Nuremberg.

Zigiranyirazo, ICTR Indictment, at para. 23, Case No. ICTR-2001-73-1 (June 20, 2001) (alleging that Zigiranyirazo "acting in concert with others, participated in the planning, preparation or execution of a common scheme, strategy, plan or campaign to exterminate the Tutsi and the political opposition to the Interim Government"); Prosecutor v. Seromba, ICTR Indictment, at para. 33, Case No. ICTR-2001-661 (June 8, 2001) (alleging that Seromba "established a plan or a common scheme to execute the extermination of Tutsi in Kivumu commune"). As far as we are aware, these indictments alleging common plan liability have not yet gone to trial at the ICTR. We thus expect the ICTR to confront and construe the ICTY's JCE jurisprudence in the near future.

136. Prosecutor v. Kayishema, Judgement, ICTR Trial Chamber, supra note 31, at paras. 203-04, (stating the members of such a group "united in this common intention [to destroy the Tutsi population] ... would be responsible for the result of any acts done in furtherance of the common design where such furtherance would be probable from those acts").

137. British common purpose doctrine, however, on which JCE is based, is used almost exclusively for acts that fall outside the main purpose of the agreement between co-conspirators. See K. J. M. Smith, A Modern Treatise on the Law of Criminal Complicity 49 (1991).

138. Marco Sassòli \& Laura M. Olson, The Judgement of the ICTY Appeals Chamber on the Merits in the Tadic Case, 82 1NT'L Rev. Red Cross 733, 749 (2000).

139. C.M.V. Clarkson \& H.M. Keating, Criminal law: Text and Materials 520 (2d ed. 1990) (questioning "why an accessory [should] be guilty of the same offence as the principal on the basis of a lesser mens rea"). In the United States, the closest equivalent to common plan liability is Pinkerton conspiracy liability, which does include liability for foreseeable crimes outside of the object of the conspiracy. However Pinkerton liability is often criticized as a substantial erosion of the principle of individual culpability. George P. Fletcher, Basic ConCePTS OF Criminal Law 192 (1998) (stating "the doctrine of conspiracy means, in effect, that it is impossible under American law to hold individuals liable simply for what they do, each according to his degree of criminal participation"); Paul Marcus, Criminal Conspiracy Law: Time to Turn Back from an Ever Expanding, Ever More Troubling Area, 1 WM. \& MARY BILL RTS. J. 1, 7 (1992) (stating Pinkerton conspiracy can amount to "guilt by association"). 
Because of the centrality of the World War II cases to contemporary debates about international criminal Iaw, the following section examines their use of criminaI organizations, conspiracy, and joint criminal enterprise. As the section reveals, the World War II cases provide almost no support for the most controversial aspects of contemporary joint criminal enterprise doctrine. Furthermore, contrary to the Appeals Chamber's assertions, joint criminal enterprise is historically and conceptually related both to conspiracy and to the prosecution of criminal organizations.

\section{JCE, Conspiracy, and Organizational Liability in World War II-era Prosecutions \\ a. JCE/Common Plan/Common Design Liability}

The cases cited in Tadic are taken from prosecutions conducted by nationaI military authorities that followed (and in some cases preceded) the proceedings at the International Military Tribunal at Nuremberg. ${ }^{140}$ They do not support the sprawling form of JCE, particularly the extended form of this kind of liability, currently employed at the ICTY. ${ }^{141}$ Instead, the cases discussed in Tadic fall into one of two types. The first involves unlawful killings of small groups of Allied POWs, either by German soldiers or by German soldiers and German townspeople. The second group of cases concerns concentration camps.

The facts of the Essen Lynching Case, in which German soldiers and civilians were convicted of killing a group of POWs, are typical of the first type of case. ${ }^{142}$ The summary of the case provided by the reporter from the United Nations War Crimes Commission (UNWCC), and upon which the Tadic court relied, provides no statement of the legal basis of the Military

140. Although these courts were established as national courts by the individual Allies, the substantive crimes they adjudicated were drawn from the international law of war. These cases have been accorded "great value" by contemporary international criminal courts. Prosecutor v. Kupreskić, Judgement, ICTY Trial Chamber, at para. 541, Case No. IT-95-I6-T (Jan. 14, 2000).

I41. Not all of the cases cited by the Appeals Chamber in Tadic are widely available. Some are recorded on non-circulating microfilm held in government archives. However, by reading the cases that are widely available, in conjunction with the descriptions given of the other eases by the Appeals Chamber, one is struck by the lack of precedent for the current form of JCE.

142. In this case, the evidence at trial indicated that, on December 13, 1944, Erich Heyer, a German army captain, put three British POWs in the custody of German army private Peter Koenen and told him to escort them through the streets of Essen to the nearest Luftwaffe unit. I UNITED Nations War Crimes Commission, The Essen Lynching Case, Trial of Erich Heyer and Six Others, British Military Court for the Trial of War Criminals, in LAW REPORTS OF TRIALS OF WAR CRIMINALS 88,88 (1947). In a loud voice on the steps of the barracks, Heyer instructed Koenen to escort the prisoners and not to interfere with any actions the crowd might take against them. This statement inflamed the passions of the crowd, and several members of the crowd attacked and killed the prisoners by throwing them off a bridge. In 1945, British authorities put five of the German civilians who attacked the POWs on trial with Heyer and Koenen. The defendants were all charged with being "concerned in the killing" of the three POWs "in violation of the laws and usages of war." Id. at 88, 90 . Heyer, Koenen, and three civilians were convicted of murder; two civilians were acquitted. Id. at 90 . 
Court's conviction of the men. ${ }^{143}$ Furthermore, there is no indication in the case that the prosecutor explicitly relied on the concept of common design, common purpose, or common plan. ${ }^{144}$ The Tadic court nevertheless cited this case as support for Category Three of JCE. It stated that "[i]t would seem warranted to infer from the arguments of the parties and the verdict" that the court found that all the defendants intended to participate in the "unlawful ill-treatment" of prisoners of war and that "the convicted persons who simply struck a blow or implicitly incited the murder could have foreseen that others would kill the prisoners; hence they too were found guilty of murder." 145

The Court's reliance on this case as an example of common plan liability, and particularly its citation of the case as support for Category Three of JCE, is dubious. Nevertheless, the facts and outcome of this case are typical of the series of POW cases that Tadic cites, some of which do explicitly rely on arguments based on "common enterprise,"146 and "common design." 147 In all of these cases, POWs are killed by small groups of people, many of whom are ultimately convicted of murder, although neither their mental state nor exact contribution to the ultimate deaths of the prisoners is clear from the facts of the case. In each one of the cases cited in Tadić, all of the defendants were present or in the immediate vicinity of the murders, and none of the defendants was charged with participation in some larger plan outside of the unlawful treatment of the prisoners involved. ${ }^{148}$

In sum, these POW mob violence cases cited in Tadić do furnish support for the Appeals Chamber's embrace of common plan in Tadić (although in several of the cases the term "common plan" is not mentioned by any party and in virtually all of the cases the ultimate legal conclusions of the military courts are unstated), and for application of the doctrine to

143. Id. at 91 .

144. By contrast, the report of the case states that the prosecutor argued that "all these seven Germans in the dock were guilty either as an accessory before the fact or as principals in the murder of the three British airmen." $I d$. at 91 .

145. Tadić V, supra note 111, at para. 209.

146. The Almelo Trial, Trial of Otto Sandrock and Three Others, British Military Court for the Trial of War Criminals, in I LAW REPORTS OF TRIALS OF WAR CRIMINALS, supra note 142, at 35, 40.

147. See Tadić V, supra note 111 , at para. 210 (discussing the Borkum 1sland case).

148. Indeed, in one of the few cases that lays out the legal principles of common plan liability, the British Judge Advocate explains:

In our law if several persons combine for an unlawful purpose or for a lawful purpose to be effected by unlawful means, and one of them, in carrying out the purpose, kills a man, it is murder in all who are present, whether they actually aid or abet or not, provided that the death was caused by a member of the party in the course of his endeavours to effect the common object of the assembly.

9 United Nations War Crimes Commission, Trial of Franz Schonfeld and Nine Others, British Military Court, in LAW Reports of Trials of WAR Criminals 64, 68 (1949). The Judge Advocate later acknowledges that a person may bc charged with this form of liability even if he is not actually present, but he must "be near enough to give assistance." $I d$. at 70 . 
the particular facts of Tadić's case. What they do not do is provide any legal basis for the sweeping JCEs, many of which span several years and extend throughout entire regions and even countries, used in later cases at the ICTY.

The other kind of World War II-era casc cited in Tadic involves prosecutions of the staff of German concentration camps. In contrast to the weak support provided in the World War II case law for Category One and Three of JCE (with the support for Category Three being especially tenuous), Category Two of contemporary JCE doctrine finds ample justification in the World War II concentration camp cases. In the U.S. prosecution of forty staff members of the Dachau Concentration Camp, for example, the indictment alleged that the defendants "acted in pursuance of a common design to commit the acts hereinafter alleged." 149 The notes provided by the UNWCC reporter to this case also set out the three legal elements that the prosecution had to show to prove this common design. ${ }^{150}$ The Tadic Appeals Chamber reproduced these requirements verbatim in its decision, and they now constitute the elements of contemporary Category Two JCEs. ${ }^{151}$ The use of JCE by international prosecutors to prosecute the staff of later-day concentration camps, therefore, finds strong support in the World War II case law, although these cases do not distinguish between common plan liability and conspiracy. Overall, however, a close reading of the World War II cases makes the Appellate Chamber's confident assertion in Tadic that, on the basis of these cases, common plan liability is "firmly established in customary international law"152 somewhat of a non sequitur.

If the extended form of JCE does not have a clear precedent in World War II-era cases, it does resemble two other controversial doctrinal stratagems used at the International Military Tribunal at Nurembergprosecution of criminal organizations and inclusion of the crime of conspiracy.

\section{b. Criminal Organizations}

Before the end of World War II, there was fierce debate among the Allies about how to treat the Nazis in the event of an Allied victory. Although the British government supported summary executions of members of the Nazi leadership, U.S. officials successfully pressed for criminal trials to adjudicate Nazi guilt. ${ }^{153}$ The decision to pursue criminal trials,

149. The Dachau Concentration Camp Trial, Trial of Martin Gottfried Weiss and Thirty-Nine Others, General Military Government Court of the United States Zone, in XI LAW REPORTS of TrIALS OF WAR CRIMINALS, supra note 142, at 5, 12.

150. Id. at 13 .

151. See Tadić V, supra note 111 , at para. 203.

152. Id. at 220 .

153. Donald Bloxham, Genocide on Trial: War Crimes Trials and the Formation of Holocaust History and MEMORY 9 (2001). 
however, did not resolve the issue of whom to try and how to manage the logistics of adjudicating the liability of the thousands of Germans who the Allies believed were guilty of participating in the Nazi schemes. Murray C. Bernays, a lawyer in the U.S. War Department, first proposed the strategy that ultimately prevailed at Nuremberg. Among other recommendations, he proposed that the Allies formally indict the major Nazi organizations. ${ }^{154}$ Under his plan, the judges of the International Military Tribunal (IMT) would try the criminality of the organizations themselves, in addition to the individual defendants indicted at Nuremberg. ${ }^{155}$ The IMT's criminal convictions of the organizations would bind military courts which would then be established individually by the Allies and which would, in subsequent proceedings, hold trials and try individuals for membership in the criminal organizations. In these secondary proceedings, the burden would be on defendants to prove that they did not join the organizations voluntarily, and a defendant's lack of knowledge of the organization's criminal purpose would not constitute a defense. ${ }^{156}$ In this way, punishment could be summarily imposed on hundreds of thousands of members of the organizations. ${ }^{157}$ In all, at least two million people were included within the ambit of the charges against the organizations ultimately indicted at Nuremberg. ${ }^{158}$

During the trial, the judges at the IMT betrayed considerable discomfort with the case against the criminal organizations. Neither the London Charter, which was the document governing the Nuremberg Trials, nor the indictment laying out the prosecution's charges provided a definition of a criminal organization. ${ }^{159}$ The judges eventually concluded that the prosecution must demonstrate that the organization must have had an existence as a group entity, such that its members would have understood that they were participating in a collective purpose. ${ }^{160}$ The judges also ruled that, to be found criminal, the criminal objectives of the organization had to be

154. This idea may have originated in a French proposal to the United Nations War Crimes Commission. See VAN SLIEDREgT, supra note 91, at 21.

155. See Stanislaw Pomorski, Conspiracy and Criminal Organizations, in The Nuremberg Trial AND INTERNATIONAL Law 213, 216 (George Ginsburgs \& V.N. Kudriavtsev eds., 1990).

156. Id. at 220 .

157. Telford Taylor, The Anatomy of the Nuremberg Trials: A Personal Memoir 75 (1992).

158. Herbert Wechsler, The Issues of the Nuremberg Trial, in Principles, Politics, and Fundamental Law: Selected Essays 138, 151 (1961). The indicted organizations were the Nazi Leadership Corps, the Gestapo/SD (Sicherheitsdienst), the SS (Schutzstaffeln), the SA (Sturmabteilungen), the Reich Cabinet (Reichsregierung), and the German General Staff and High Command. Indictment, in 1 TRIAL OF THE MAJOR WAR CRIMINAls Before THE INTERNATIONAL Military Tribunal: Nuremberg, I4 November I945-I OCtober I946, supra note 12, at 27, 80-82 [hereinafter Nuremberg Indictment].

159. Ana TuSa \& John Tusa, The Nuremberg Trial 425 (1984).

160. Nuremberg Judgement, supra note 12, at 278. 
pervasive and shared among its members. ${ }^{161}$ Ultimately, the IMT judges acquitted four of the seven indicted organizations; they found criminal only the Leadership Corps, the Gestapo, and the SS (Schutzstaffeln). ${ }^{162}$

Finally, the judges shifted the burden of proof and ruled that, in subsequent proceedings, the prosecution must prove that any person prosecuted for membership in a criminal organization joined the organization voluntarily and knew that the organization engaged in crimes within the jurisdiction of the London Charter. If the prosecution could not demonstrate the latter, the prosecution had to show that the defendant personally participated in such crimes. ${ }^{163}$ With this ruling, the IMT effectively negated the procedural benefits to the prosecution that Bernays had anticipated would flow from the conviction of criminal organizations. In subsequent proceedings, the prosecution was now forced to bear the burden of proving each individual's voluntary and knowing participation in a group with criminal aims. ${ }^{164}$ Ultimately, Bernays's vision of thousands of summary trials was replaced by the administrative denazification program instituted by the Allies, and subsequent trials for membership in criminal organizations largely did not materialize. ${ }^{165}$

\section{c. Conspiracy}

For those familiar with U.S. conspiracy law, Bernays's Plan should have a familiar ring. Indeed, Bernays's original proposal explicitly describes conspiracy as the legal vehicle through which mass convictions would ensue. In his now-famous memorandum, Bernays wrote:

The Nazi Government and its Party and State agencies ... should be charged before an appropriately constituted international court with conspiracy to commit murder, terrorism, and the destruction of peaceful populations in violation of the laws of war.... [O]nce the conspiracy is established, each act of every member thereof during its continuance and in furtherance of its purposes would be imputable to all other members thereof. ${ }^{166}$

In its judgement, the IMT also made the link between criminal organizations and conspiracy explicit. It declared that "[a] criminal organization is analogous to a criminal conspiracy in that the essence of

161. WECHSLER, supra note 158, at 151-52.

162. TAYLOR, supra note 157 , at 584-85.

163. Id. at 558 .

164. WECHSLER, supra note 158 , at 152.

165. TAYLOR, supra note 157 , at 279,638 .

166. Colonel Murray C. Bernays, G-1, Subject: Trial of European War Criminals, in THE American Road to Nuremberg: The Documentary Record 1944-1945, at 33, 36-37 (Bradley F. Smith ed., 1982) (footnote omitted). 
both is cooperation for criminal purposes. There must be a group bound together and organized for a common purpose." 167

Conspiracy was controversial at Nuremberg, both because of the absence of this crime in continental criminal systems and because of the perceived malleability of conspiracy to aggressive prosecutorial strategies. ${ }^{168}$ As Bradley Smith has famously reported of the debates among the Allies over inelusion of the crime of conspiracy in the London Charter:

During much of the discussion, the Russians and French seemed unable to grasp all the implications of the concept; when they finally did grasp it, they were genuinely shocked. The French viewed it entirely as a barbarous legal mechanism unworthy of modern law, while the Soviets seemed to have shaken their head in wonderment-a reaction, some cynics may believe, prompted by envy. ${ }^{169}$

Despite French and Soviet objection to the ideas of conspiracy and criminal organizations, both were ultimately deployed at Nuremberg. Article 6 of the Nuremberg Charter criminalizes conspiracy to commit a Crime Against Peace (the initiating or waging of aggressive war) and also declares that "[1]eaders, organizers, instigators and accomplices participating in the formulation or execution of a Common Plan or Conspiracy to commit any of the foregoing crimes [Crimes Against Peaee, War Crimes, and Crimes Against Humanity] are responsible for all acts performed by any persons in execution of such plan." 170 This latter provision does not refer to conspiracy as a substantive crime but instead provides that conspirators should be liable for all crimes committed in execution of a "common plan or conspiracy." 171

The concept of imputed liability for co-conspirators was well known in common law jurisdictions at the time, and one year later would be endorsed by the U.S. Supreme Court in Pinkerton v. United States. ${ }^{172}$ This kind of liability for co-conspirators has not been embraced in any civil law jurisdictions. ${ }^{173}$ Today, many U.S. states, as well as the influential Model

167. Nuremberg Judgement, supra note 12 , at 256.

168. Pomorski, supra note 155 , at 216-17.

169. Id. at 218 (quoting BRADLEY F. SMITH, REACHING JudgEMENT AT NuREMBERG 51 (1977)).

170. Charter of the International Military Tribunal, in I TRIAL OF THE MAJOR WAR CRIMINALS Before the lnternational Military Tribunal: Nuremberg, i4 November I945-I October I946, supra note 12, at 10, 11. Conspiracy to commit War Crimes or Crimes Against Humanity was not included as a substantive crime in the Charter. $I d$.

171. See Pomorski, supra note 155 , at 224.

172. 328 U.S. 640 (1946). lronically, three years later, Pinkerton's embrace of this principle would be criticized by Justice Jackson, the U.S. Prosecutor at Nuremberg and a principal drafter of the London Charter, as endorsing a "novel and dubious theory that conspiracy is equivalent in law to aiding and abetting." Krulewitch v. United States, 336 U.S. 440, 451 (1949) (Jackson, J., concurring).

173. Edward M. Wise, RICO and Its Analogues: Some Comparative Considerations, 27 SYRACuSE J. INT'L L. \& Сом. 303, 312 (2000). 
Penal Code, have rejected Pinkerton liability, although it still plays a prominent role in federal prosecutions. ${ }^{174}$

Just as Pinkerton intertwines conspiracy as a substantive crime with conspiracy as a theory of liability, the Nuremberg Charter, Indictment, and Judgement also use conspiracy in this way. Count One of the Indictment is illustrative of the way conspiracy was used at Nuremberg. It alleged that all of the defendants,

during a period of years preceding 8 May I945, participated as leaders, organizers, instigators, or accomplices in the formulation or execution of a common plan or conspiracy to commit ... Crimes against Peace, War Crimes, and Crimes against Humanity ... and, in accordance with the provisions of the Charter, are individually responsible for their own acts and for all acts committed by any persons in the execution of such plan or conspiracy. ${ }^{175}$

Thus, conspiracy constituted both a substantive crime (conspiracy to commit Crimes Against Peace) and provided a theory of liability such that each defendant could bc convicted for any acts committed by others "in the execution of such plan or conspiracy."

This wide-ranging and aggressive use of conspiracy provoked "the largest and most persistent legal controversy of the trial."176 The Judgement eventually handed down, which stretches over one hundred pages, contains a three-page section entitled "The Law as to the Common Plan or Conspiracy." 177 In this section, the IMT judges endorsed a restrictive notion of conspiracy ${ }^{178}$ and rejected the application of conspiracy to Crimes Against Humanity and War Crimes. ${ }^{179}$ The judges also ultimately limited conviction of conspiracy to commit aggressive war to those who numbered among Hitler's senior leadership and who actively participated in the planning of aggression. ${ }^{180}$ Using these criteria, the judges found that "the evidence establishes the common planning to prepare and wage war by certain of the defendants."181 Of the twenty-two defendants charged with conspiracy, only eight were convicted, and conspiracy did not figure prominently in the sentences ultimately imposed. ${ }^{182}$ Furthermore, the Judgement does not mention either conspiracy or common plan liability in

174. Sanford H. Kadish \& Stephen J. Schulholfer, Criminal Law and Its Processes: CASES AND MATERIALS 693 (7th ed. 2001).

175. Nuremberg Indictment, supra note 158 , at 29.

176. Pomorski, supra note 155 , at 229.

177. Nuremberg Judgement, supra note 12, at 224-26.

178. The Judgement does not provide a definition of conspiracy but does state that "the conspiracy must be clearly outlined in its criminal purpose. 1t must not be too far removed from the time of decision and of action." Id. at 225.

179. Pomorski, supra note 155 , at 233-35.

180. Id.

181. Nuremberg Judgement, supra note 12, at 225.

182. Pomorski, supra note 155 , at 229. 
its discussion of the individual defendants' convictions for Crimes Against Humanity and War Crimes. Ultimately, the scope of the conspiracy charge at Nuremberg was narrowed significantly by the IMT judges, and it played a prominent role only with regard to Crimes Against Peace.

Although the term "common plan" (which is used synonymously in contemporary international criminal law cases with "joint criminal enterprise") appears in the Nuremberg Charter, Indictment, and Judgement, it was not discussed in these documents separately from conspiracy. Moving ahead fifty years, the Tadić court did not mention Nuremberg at all in its review of the precedents for common plan liability; the court relied instead on the national prosecutions discussed above.

\section{d. Nuremberg Revisited: Contemporary JCE, Conspiracy, and Criminal Organizational Liability}

Both Bernays's description of the purposes of the criminal organization charge and the IMT's lukewarm endorsement of the concept share important similarities with JCE. Each of these doctrinal stratagems serves to expand the potential liability of defendants far beyond their physical perpetration of crimes. Each harnesses the criminal liability of the defendants to the acts committed within the scope of the enterprise and, in the case of Category Three JCEs, to those beyond the scope of the criminal purpose.

In addition, membership in a criminal organization is itself a crime in many jurisdictions. ${ }^{183}$ Like its international cognate, this crime bears a close relationship with principles of collective responsibility, as do complicity, common plan, and conspiracy liability. ${ }^{184}$ Indeed, an analysis of all of the post-World War II war crimes trials published by the United Nations War Crimes Commission in 1949 equates the Nuremberg criminal organizations charge with JCE:

[T] he history of the development of the concept of membership [in a criminal organization] suggests strongly that what it was to punish was no mere conspiracy to commit crimes but a knowing

183. See, e.g., C. PEN. 450-1 (French statute making it a crime to be a member of an association of wrongdoers); $\S 129 \mathrm{Nr} .1$ StPO (Stephen Thaman trans., 2002) (German penal code statute making it a crime to be a member of an "organization, the objectives or activity of which are directed towards the commission of crimes"). For discussion of these statutes, see Wise, supra note 173, at 312-20; Alexander D. Tripp, Margins of the Mob: A Comparison of Reves v. Emst \& Young with Criminal Association Laws in Italy and France, 20 FORDHAM INT'L L.J. 263, 265 (1996).

184. Tripp, supra note 183, at 265 (noting that "[i]n Italy and France, criminal groups are prosecuted under laws prohibiting criminal associations"). In Scales $v$. United States, for example, the U.S. Supreme Court examined the constitutionality of a statute that made it a crime to be a member of an organization advocating the overthrow of the government of the United States by force or violence. 367 U.S. 203, 205 n.l (1961). Rejecting the contention that this statute unlawfully contravened the guarantee of the due process clause that "guilt is personal," the Court noted that "[a]ny thought that due process puts beyond the reach of the criminal law all individual associational relationships, unless accompanied by the commission of specific acts of criminality, is dispelled by familiar concepts of the law of conspiracy and complicity." Id. at 224-25. 
and voluntary membership of organisations which did in fact commit crimes, and those on a wide scale. Viewed in this light, membership resembles more the crime of acting in pursuance of a common design than it does that of conspiracy. ${ }^{185}$

Given the close doctrinal link between the criminal organization charges at Nuremberg and the concept of JCE, it is notable that neither Tadic nor any subsequent case from the ICTY has relied on either criminal organizations concepts or on the use of conspiracy and common plan at the Nuremberg Trial to justify JCE's status as a matter of customary international law. ${ }^{186}$ This silence is unusual, since contemporary international criminal courts typically treat Nuremberg precedent as canonical. Furthermore, at least one other opinion from the ICTY states that conspiracy forms part of customary international law because of its inclusion in the London Charter. ${ }^{187}$

When defendants have alleged that JCE is simply a "vehicle for organizational liability," the ICTY judiciary has vehemently denied the charge. ${ }^{188}$ The Appeals Chamber has declared that "[c]riminal liability pursuant to a joint criminal enterprise is not liability for mere membership or for conspiring to commit crimes, but a form of liability concerned with the participation in the commission of a crime as part of a joint criminal enterprise, a different matter." 189 Another Trial Chamber has asserted that "joint criminal enterprise can not be viewed as membership in an organisation because this would constitute a new crime not foreseen under the Statute and therefore [would] amount to a flagrant infringement of the principle nullum crimen sine lege." 190

It should be noted that, despite the close similarities between JCE and conspiracy (either as it is recognized under international or municipal law), they are distinct. Most notably, JCE never constitutes a substantive crime, while conspiracy may act both as a substantive crime and as a theory of liability. Both conspiracy ${ }^{191}$ and JCE require an agreement among individuals to commit a crime, although the ICTY jurisprudence does not clearly state what the agreement must entail. Presumably, the agreement is

185. Types of Offences, in XV LAW REPORTS OF TRIALS of WAR CRIMINALS, supra note 148, at 89, 98-99 (citations omitted).

186. Judge Hunt of Australia, however, has recognized the close relationship between Category Two of JCE and the criminal organization provisions. Prosecutor v. Multinovic, Separate Opinion of Judge David Hunt on Challenge by Ojdanić to Jurisdiction-Joint Criminal Enterprise, ICTY Appeals Chamber, at para. 30, Case No. IT-99-37-AR72 (May 21, 2003).

187. Prosecutor v. Erdemović, Joint Separate Opinion of Judge McDonald and Judge Vohrah, ICTY Appeals Chamber, at para. 51, Case No. IT-96-22-A (Oct. 7, 1997).

188. Prosecutor v. Multinović, Decision on Dragoljub Ojdanićs Motion Challenging Jurisdiction-Joint Criminal Enterprise, ICTY Appeals Chamber, at para. 24, Case No. IT-99-37AR72 (May 21, 2003).

189. Id. at para. 26.

190. Prosecutor v. Stakić, Judgement, ICTY Trial Chamber, at para. 433, Case No. IT-97-24-T (July 31, 2003).

191. See LAFAvE, supra note 22 , at 475 . 
to execute a "common criminal plan."192 The common law version of conspiracy does not require any "overt acts" taken in furtherance of the agreement, although many U.S. statutes do include such a requirement. JCE, by contrast, requires "that the parties to that agreement took action in furtherance of the agreement." ${ }^{\prime 193}$ The Appeals Chamber has stated that JCE's requirement of "the commission of criminal acts in furtherance of that enterprise" distinguishes it from conspiracy, which merely calls for an agreement. ${ }^{194}$ Since many jurisdictions that criminalize conspiracy also mandate that an overt act be committed in furtherance of the agreement, ${ }^{195}$ it is not clear whether this formal distinction between JCE and conspiracy carries much practical weight. Furthermore, international judges fail to acknowledge that conspiracy is not only a substantive crime but also constitutes a liability theory in its own right. For example, Judge Hunt of Australia, a leading authority on JCE at the ICTY, ${ }^{196}$ has characterized the argument that JCE is a form of conspiracy as "entirely fallacious. Conspiracy is not a mode of individual criminal responsibility for the commission of a crime." 197 Nevertheless, as Pinkerton demonstrates, conspiracy (at least as practiced in some U.S. jurisdictions) does play an important role as a liability theory and also functions in ways virtually identical to JCE.

The ICTY's efforts to distance itself from these aspects of Nuremberg are hardly surprising. Both the criminal organization and conspiracy charges of the Nuremberg prosecution were the subject of significant criticism. ${ }^{198}$ In 1944, Assistant Attorney General Herbert Wechsler wrote to the Attorney General criticizing the expansive scope of the organizations charge. He argued that the force of the charges would be weakened "if too many individuals are included within it" and that proof of the criminality of the defendants would best be accomplished "only by proof of personal

192. See Prosecutor v. Stakić, Judgement, ICTY Trial Chamber, at para. 435, Case No. IT-97-24-T (July 31, 2003) (stating that, for all three categories of JCE, "the Prosecution must prove ... the existence of a common criminal plan between two or more persons in which the accused was a participant. The existence of the agreement or understanding need not be express, but may be inferred from all the circumstances."). But see Barrett \& Little, supra note 86 , at $42-43$ (arguing that JCE does not require proof of an agreement).

193. Prosecutor v. Multinović, Decision on Dragoljub Ojdanićs Motion Challenging Jurisdiction-Joint Criminal Enterprise, ICTY Appeals Chamber, at para. 23, Case No. IT-99-37AR72 (May 21, 2003).

194. Id.

195. LAFAVE, supra note 22 , at 626 (noting that "most of the [U.S.] states now require that an overt act in furtherance of the plan be proven for all of specified conspiratorial objectives" and "on the federal level, an overt act is specifically required by the general conspiracy statute").

196. In 2003, Judge Hunt stepped down from the ICTY.

197. Prosecutor v. Multinović, Separate Opinion of Judge David Hunt on Challenge by Ojdanićc to Jurisdiction-Joint Criminal Enterprise, ICTY Appeals Chamber, at para. 23, Case No. IT-99-37-AR72 (May 21, 2003).

198. E.g., Pomorski, supra note 155 , at 218 (noting controversy over the criminal organizations plan during the drafting of the IMT Charter). 
participation in specific crimcs."199 In the end, the IMT Judgement eschewed the most controversial implications of the organizational and conspiracy charges by defining conspiracy narrowly and by requiring the prosecution to prove voluntary membership and individual knowledge in subsequent prosecutions of members of criminal organizations. The IMT Judgement justified these limitations by stating that they were "in accordance with well settled legal principles, one of the most important of which is that criminal guilt is personal, and that mass punishment should be avoided." 200 As we discuss further in Part IV, this critical insight has been given insufficient attention in the recent development of joint criminal enterprise.

\section{B. The Development of Command Responsibility}

\section{Doctrinal Overview}

Command responsibility doctrine allows military and civilian leaders to be held liable for the criminal acts of their subordinates. The doctrine cncompasses two different forms of liability. The first is direct or active command responsibility - when the leader takes active steps to bring about the crime by, for example, ordering his subordinates to do something unlawful. Active command responsibility falls within Article $7(1)$ of the ICTY Statute and the parallel provisions of the ICTR and ICC Statutes; a commander who engages in positive acts to encourage his subordinates to commit crimes will be found to havc "planned, instigated, ordered, committed or otherwise aided and abettcd in the planning, preparation, or execution of a crime."201

The second type of command responsibility (and the one to which people usually refer when they speak generally of "command responsibility"), involves "indirect" or "passive" command responsibility. ${ }^{202}$ Because direct proof that a commander actually ordered his troops to commit crimes is not always forthcoming, the second type of command responsibility is more significant in both theory and practice as a distinct theory of liability, and it is this type of command responsibility on which this section of the Article focuses. Indirect command responsibility arises

199. Herbert Wechsler, Memorandum for the Attorney General (Francis Biddle) from the Assistant Attorney General (Herbert Wechsler), in THE AMERICAN RoAD TO NuREMBERG: DOCUMENTARY RECORD I944-1945, supra note 166, at 84, 89.

200. Nuremberg Judgement, supra note 12, at 256.

201. ICTY STATUTE, supra note 9, at art. 7(1); see ICTR STATUTE, supra note 9, at art. 6(1); ICC STATUTE, supra note 9, at art. 25; see also Prosecutor v. Delalić, Judgement, ICTY Trial Chamber, supra note 30 , at para. 334.

202. However, some opinions have suggested that the omissions of a commander may also give rise to aiding and abetting liability under 7(1). See Prosecutor v. Kordić, Judgement, 1CTY Trial Chamber, supra note 102, at para. 371 ("Where the omissions of an accused in a position of superior authority contribute (for instance by encouraging the perpetrator) to the commission of a crime by a subordinate, the conduct of the superior may constitute a basis for liability under Article 7(1)."). 
from the culpable omissions of commanders or superiors, and is covered by separate provisions in each of the statutes. Article 7(3) of the ICTY Statute, for example, provides that:

The fact that any of the acts referred to in articles 2 to 5 of the present Statute was committed by a subordinate does not relieve his superior of criminal responsibility if he knew or had reason to know that the subordinate was about to commit such acts or had done so and the superior failed to take the necessary and reasonable measures to prevent such acts or to punish the perpetrators thereof. ${ }^{203}$

The ICC Statute contains a similar provision, although its language is slightly different. This provision imposes liability on military commanders who "knew or, owing to the circumstances at the time, should have known" as well as civilian leaders who "knew, or consciously disregarded information which clearly indicated" that their subordinates were committing or were about to commit crimes. ${ }^{204}$

The Secretary-General's report on the establishment of the ICTY explains that, when a commander is "held responsible for failure to prevent a crime or to deter the unlawful behaviour of his subordinates," this is a form of "imputed responsibility or criminal negligence." ${ }^{205}$ It is important to realize that, under command responsibility, the commander is convicted of the actual crime committed by his subordinate and not of some lesser form of liability, such as dereliction of duty. Liability for serious crimes based on omissions, let alone negligent omissions, is unusual in criminal law. The doctrine thus depends on the notion that the omission is culpable because international law imposes an affirmative duty on superiors to prevent and punish crimes by their subordinates. ${ }^{206}$ As the U.S. Supreme Court explained in the Yamashita case, "the law of war presupposes that its violation is to be avoided through the control of the operations of war by commanders who are to some extent responsible for their subordinates."207 The Court further stated that a military commander has "an affirmative

203. ICTY StatuTE, supra note 9, at art. 7(3). Article 6(3) of the ICTR Statute provides an essentially identical provision, as do the statutes for the Sierra Leonc and East Timor special courts. United Nations, Statute for the SPecial Court in Sierra Leone, supra note 3, at art. 6(3); U.N. TRANSITIONAL ADMINISTRATION IN EAST TIMOR, supra note 3, at art. 16.

204. ICC STATUTE, supra note 9, at art. 28.

205. SeCRETARY-GENERAL OF THE U.N., supra note 29, at para. 56. As discussed infra, the notion that "negligence" can support a convietion for command responsibility is highly controversial.

206. See Timothy Wu \& Yong-Sung (Johnathan) Kang, Criminal Liability for the Actions of Subordinates-the Doctrine of Command Responsibility and its Analogues in United States Law, 38 HARV. INT'L L.J. 272, 290 (1997).

207. In re Yamashita, 327 U.S. I, 15 (I946). 
duty to take such measures as [are] within his power and appropriate in the circumstances to protect prisoners of war and the civilian population."208

Command responsibility doctrine under the case law of the ICTY and ICTR requires three elements:

1. the existence of a superior-subordinate relationship of effective control;

2. the existence of the requisite mens rea, namely that the commander knew or had reason to know of his subordinates' crimes; and

3. that the commander failed to take the necessary steps to prevent or punish the offenses. ${ }^{209}$

While the elements of the doctrine are well-established, these requirements have proved controversial in application. Most of the debate has focused on the first two elements. Whon a defendant is found to have had both a relationship of effective control over subordinates and the requisite knowledge of their crimes, then absent some extraordinary proof, it will almost always follow that he failed to take the necessary steps to prevent and punish those crimes. After all, if he had taken the necessary preventive steps, the troops under his effective control would likely not have committed the crimes (or if rogue actors, at least would have been promptly punished). Moreover, as the ICTY Appeals Chamber has explained, determining the necessary and appropriate steps to prevent crimes in any given circumstance will almost always resolve to a factual question, and is not readily susceptible to articulation as a general legal standard. ${ }^{210}$ Thus, the sections below trace the evolution of the doctrine, focusing on more controversial elements of effective control and mens rea.

\section{The Origins of Command Responsibility Doctrine}

Command responsibility doctrine originated in international humanitarian law. Although its roots probably go deeper, ${ }^{211}$ modern international law's imposition of an affirmative duty on military commanders to prevent war crimes is usually traced to the Hague Conventions of $1907 .^{212}$

208. Id. at 16. The dissent apparently accepted that a military commander could be punished "for clear and unlawful failures to prevent atrocities," but believed that General Yamashita's conduct did not fall within this category and that the standard of liability imposed by the eommission was not based on pre-existing law. Id. at 40 (Murphy, J., dissenting).

209. See Prosecutor v. Blaškié, Judgement, 1CTY Trial Chamber, at para. 294, Case No. IT-95-14T (Mar. 3, 2000); Prosecutor v. Delalić, Judgement, ICTY Trial Chamber, supra note 30, at para. 346; Prosecutor v. Kordić, Judgement, ICTY Trial Chamber, supra note 102, at para. 401

210. Blaškić Appeals Judgement, supra note 104, at para. 294.

211. See Major William H. Parks, Command Responsibility for War Crimes, 62 MIL. L. REv. 1, 2 10 (1973) (tracing origin of command responsibility from 500 B.C. to World War 11); Major Michael L. Smidt, Yamashita, Medina and Beyond: Command Responsibility in Contemporary Military Operations, 164 MIL. L. REv. 155, 169-71 (2000) (tracing the origin of eomınand responsibility).

212. See, e.g., In re Yamashita, 327 U.S. at 15-16 (citing the 1907 Hague Convention); SECOND Peace Conference of the Hague, supra note 9, at art. I (noting that "laws, rights and duties of war" 
Following World War I, recommendations were made that high-level German military leaders be tried for war crimes committed by their subordinates, although in the end no international tribunal was created and only a few offenders were tried before German national courts. ${ }^{213}$ The obligation for commanders became further entrenched in later treaties on the laws of war. For example, the 1929 Geneva Convention for the Amelioration of the Condition of the Wounded and Sick in Armies in the Field reiterated that the duty of "Commanders-in-chief of belligerent armies [is to] arrange the details for carrying out the preceding articles [of the Convention]."214

The doctrine was then applied in several of the post-World War II proceedings ${ }^{215}$-most famously in the notorious trial of Tomoyuki Yamashita, the commanding general of the Imperial Japanese Army in the Philippines, who was convicted and sentenced to death by a U.S. military commission for atrocities committed by troops under his command. The case eventually reached the U.S. Supreme Court, which upheld the conviction in a split decision over vigorous dissent. ${ }^{216}$

The military commission based its conviction of General Yamashita on the fact that the atrocities by Japanese forces "were not sporadic in nature but in many cases were methodically supervised by Japanese officers and non-commissioned officers" and that General Yamashita "failed to provide effective control of [his] troops as required by the circumstances." 217 But while the evidence of widespread and vicious crimes by the Japanese army was clear, the evidence of General Yamashita's knowledge of and involvement with those crimes was not. General Yamashita's defense was that an aggressive U.S. military counteroffensive had effectively cut off his chain of command and communication, rendering him incapable of knowing about or preventing the crimes. ${ }^{218}$

apply to armies, militias, and volunteer corps that are "commanded by a person responsible for his subordinates"); see also id. at art. 43 (requiring occupant of foreign territory to "take all measures in his power to restore, and ensure, as far as possible, public order and safety").

213. Parks, supra note 211, at 11-13.

214. See Convention for the Amelioration of the Condition of the Wounded and Sick IN ARMies in THE FIELD, at art. 26, 118 L.N.T.S. 303 (June 19, 1931).

215. See, e.g., 8 United Nations War CRImes Commission, Trial of Wilhelm List and Others, United States Military Tribunal (The Hostages Trial), in LAW REPORTS OF TRIALS OF WAR CRIMINALS 34 (1949). Interestingly, none of the statutory texts creating the post-World War 11 tribunals-the Nuremberg Charter, Control Council Law No. 10 (which govemed the subsequent trials of lower-level Nazi war criminals), and the Charter of the International Military Tribunal for the Far East-contained explicit provisions on the responsibility of commanders for acts by their subordinates. See Smidt, supra note 211 , at $175-76$.

216. In re Yamashita, 327 U.S. at 17.

217. 4 UNited Nations WAR CRIMEs Commission, Trial of General Tomoyuki Yamashita, in LaW Reports of Trials of War Criminals 35 (1948).

218. A. Frank Reel, The Case of General Yamashita 17 (1949). 
The criticism of the Yamashita decision was immediate and has not abated in the intervening half-century. ${ }^{219}$ Indeed, in many ways, the evolution of command responsibility doctrine has consisted of reactions and counter-reactions to Yamashita. To begin with, it is not clear which mens rea standard was actually applied in Yamashita. Some critics, including Justice Rutledge in his dissent at the U.S. Supreme Court, have said that the commission applied a standard tantamount to strict liability or guilt by association. ${ }^{220}$ Others have argued that a fairer reading of the case is that the commission rejected Yamashita's claims of ignorance and inferred actual knowledge from the circumstantial evidence. ${ }^{221}$ Yamashita also left unclear the level of effective control a commander must possess to be liable. In his dissent, Justice Murphy focused on General Yamashita's inability, owing to the chaotic circumstances of battle, to actually do anything to control his troops. ${ }^{222}$ Justice Murphy was of the opinion that " $[\mathrm{t}] \mathrm{o}$ use the very inefficiency and disorganization created by the victorious forces as the primary basis for condemning officers of the defeated armies bears no resemblance to justice or to military reality."223 Other World War II era cases applying command responsibility doctrine did little to clarify either the mens rea or the degree of effective control required. ${ }^{224}$

\section{Evolution of Command Responsibility Doctrine}

Much of the controversy over Yamashita and modern-day command responsibility cases has stemmed from issues of evidence and proof. Because indirect or passive command responsibility cases are based mostly on circumstantial evidence, they involve difficult inferential judgements

219. See, e.g., id;; M. Cherif Bassiouni, From Versailles to Rwanda in Seventy-Five Years: The Need to Establish a Permanent International Criminal Court, 10 HARv. HuM. RTs. J. 11, 36-37 (1997); Damaška, supra note 19, at 481 (2001).

220. Justice Rutledge noted that the commission "nowhere expressly declares that knowledge was essential to guilt" and that it was "impossible" to determine whether Yamashita had been convicted for a "willful, informed and intentional omission" or "a negligent failure on his part to discover this and take whatever measures he then could to stop the conduct." In re Yamashita, 327 U.S. at 52-53 (Rutledge, J., dissenting).

221. See, e.g., Parks, supra note 211 , at 30-38.

222. In re Yamashita, 327 U.S. at 35 (Murphy, J., dissenting).

223. Id. (Murphy, J., dissenting). Procedural irregularities in the trial were also the subject of dissent. See id. at 40-41; id. at 42 (Rutledge, J., dissenting).

224. Compare, e.g., The Tokyo War Crimes Trial, The International Military Tribunal for the Far EAst, Judgement 48, 444-45, reprinted in The Tokyo Major War Crimes Trial (R. John Pritchard ed., Edwin Mellen Press 1998) (holding that superiors could be held responsible not only where "they had knowledge that such crimes were being committed" but also where "they are at fault in having failed to acquire such knowledge" based on "negligence or supineness") with 8 UNITED NATIONS WAR CRIMES Commission, supra note 215, at 34 (noting that a commander will not "ordinarily be permitted to deny knowledge of happenings within his area of command while he is present therein" and "is charged with notice of occurrences taking place within that territory. ... If he fails to require and obtain complete information, the dereliction of duty rests upon him and he is in no position to plead his own dereliction as a defense."). 
about what a commander should have known and should have done differently. These circumstantial judgements, like many other factual conclusions in such trials, are highly contestable for those inclined by political sympathy to view the evidence more charitably to the defendant. The failure of some courts and tribunals, beginning with Yamashita, to precisely articulate what legal standards they are applying in terms of mens rea and proof of effective control has generated an equal, if not greater, measure of controversy, inviting accusations that convictions are based on something akin to strict liability. Recently, the ICTY and ICTR Appeals Chambers have taken pains to clarify the legal standards on both mens rea and effective control, laying to rest many concerns about the doctrine that have been in the air since World War II. Below, we briefly trace some of the significant doctrinal developments and the concerns that have animated such developments.

\section{a. Mens Rea Requirement}

Not surprisingly, the mens rea requirement has been the focus of most of the doctrinal reform and development. Specifically, the debate has centered on whether a commander must have had actual knowledge of the violations committed by his subordinates to be derivatively liable for them, or whether he may be found guilty of crimes of which he had no actual knowledge. In the latter case, a subsidiary issue is the precise level of dereliction of duty he must have exhibited-recklessness, gross negligence, ordinary negligence-or even whether strict liability is appropriate. ${ }^{25}$ Given the difficulty of making these fine-grained distinctions about mental state based on largely circumstantial evidence, the amount of time and effort devoted by treaty-makers, judges, lawyers, and commentators to finely distinguishing these gradations of mens rea is noteworthy and suggests some deep animating concern at work in this area. As explained further in Part IV, we believe these doctrinal controversies are evidence of the search for the appropriate culpability model for the wrongdoing captured by command responsibility.

Yamashita and the other post-World War II cases left the mens rea requirement for command responsibility unclear, and developments in the intervening decades failed to clarify the situation. Although the proper scope of command responsibility arose in only a handful of national cases between World War II and the creation of the ad hoc tribunals in the $1990 s^{226}$ the I977 Additional Protocol I to the Geneva Conventions

225. Adding to the confusion is the inconsistency in the meaning of terms such as recklessness and negligence across national legal systems, many of which employ different terminology or use the same terminology but with different meanings. In this Article, we generally use these terms as used within the U.S. legal system.

226. See Parks, supra note 211, at 1 (stating that the My Lai massacre has generated questions concerning command responsibility); see also L. C. Green, Command Responsibility in International 
addresses the topic. It provides that superiors are not absolved of criminal responsibility for breaches committed by their subordinates, if "they knew or had information which should have enabled them to conclude in the circumstances at the time, that [the subordinate] was committing or was going to commit such a breach and if they did not take all feasible measures within their power to prevent or repress the breach." ${ }^{\prime 227}$ Although this provision appears to sanction some form of negligence as a permissible mens rea, there was a discrepancy between the equally authoritative English and French versions of the text, leading to further confusion about the requirement. The French version read "des informations leur permettant de conclure," which translates more closely to "information enabling them to conclude" rather than to the English "information which should have enabled them to conclude." 228 The authoritative commentary provided by the International Committee of the Red Cross notes the "significant discrepancy" between the translations and suggests that the French version should be followed because it is more consistent with the object and purpose of the treaty, ${ }^{229}$ but the Commentary's reasoning itself is not entirely clear. ${ }^{230}$

The statutes of the ICTY and ICTR brought further textual guidance, stating that an accused is liable where she "knew or had reason to know that the subordinate was about to commit such acts or had done so and the superior failed to take the necessary and reasonable measures to prevent such acts or to punish the perpetrators thereof."231 Thus, the ICTY and ICTR statutes endorse liability for something less than actual knowledge,

Humanitarian Law, 5 Transnat'l. Law \& Contemp. Probs. 319 (1995) (describing cases involving command responsibility); see generally Lieutenant Commander Weston D. Burnett, Command Responsibility and a Case Study of the Criminal Responsibility of Israeli Military Commanders for the Pogrom at Shatila and Sabra, 107 MiL. L. REv. 71, 80 (1985).

227. Protoeol Additional to the Geneva Conventions of 12 August 1949, and Relating to the Protection of Victims of International Armed Conflicts (Protocol 1), at art. 86(2) (June 8, 1977), available at http://www.icrc.org/ihl.

228. International Committee of the Red Cross, Commentary on Protocol I Additional to The Geneva Conventions of 1949, at 1013, available at http://www.icrc.org/ihl. In addition to pointing out this ambiguity, the ICRC eommentary attempts to shed light on some of the other issues raised by the doctrine; for example, it notes that objections had been raised to the difficulty of establishing intent (mens rea) in case of a failure to act, particularly in the case of negligence. The commentary emphasizes that not all negligence may give rise to liability; rather, "the negligence must be so serious that it is tantamount to malicious intent, apart from any link between the conduct in question and the damage that took place." $I d$. at 1011 .

229. The ICRC Commentary is widely viewed as authoritative on the meaning of the Conventions. See, e.g., Department of the Army, Judge advocate General's Humanitarian Law Handbook 4 (2002) ("[The ICRC] 'Commentaries' provide critical explanations of many treaty provisions, and are therefore similar to 'legislative history' in the domestic context.').

230. Id.

231. ICTR STATUTE, supra note 9, at art. 6(3); ICTY STATUTE, supra note 9, at art. 7(3); see also United Nations, Statute for the Special Court in Sierra Leone, supra note 3, at art. 6(3) (using similar language); U.N. Transitional Administration in EASt Timor, supra note 3, at art. 16 (using similar language). 
although, as discussed below, these tribunals have wrestled with the proper interpretation of "had reason to know," with a definitive interpretation of these words emerging only in the most recent cases.

Throughout much of the ICTY and ICTR case law, there has been evident concern with avoiding the possibility of strict liability and discomfort with liability based on ordinary negligence. One early decision in which such concern appears is the ICTR Trial Chamber's judgement in Akayesu. ${ }^{232}$ There, the Trial Chamber emphasized that command responsibility derives from the principle of individual criminal responsibility and noted that such responsibility should be based on malicious intent, or at least negligence "so serious as to be tantamount to acquiescence or even malicious intent." 233

The ICTY's judgement in the Čelebić $i$ camp case, rendered a few weeks after the Akayesu decision, likewise rejected a negligence standard. ${ }^{234}$ The Čelebici $i$ Trial Chamber held that the requisite knowledge could be shown by direct evidence or established by circumstantial evidence. ${ }^{235}$ The Trial Chamber opined that "a superior is not permitted to remain willfully blind to the acts of his subordinates," yet acknowledged that difficulties arise in situations where the superior lacks information of his subordinates' crimes because he failed to properly supervise them. ${ }^{236}$ While recognizing that some of the post-World War II case law suggested that a commander may be held liable where he willfully failed to acquire knowledge of his subordinates' activities, ${ }^{237}$ the Chamber found that, at the time the offenses occurred in the former Yugoslavia, customary international law allowed a superior to be held criminally responsible "only if some specific information was in fact available to him which would provide notice of offences committed by his subordinates." 238 Such information need not provide conclusive proof of the crimes, but must be enough to demonstrate that additional investigation into the subordinates' actions was necessary. ${ }^{239}$ Thus, Čelebici embraces something akin to a recklessness requirement. The Appeals Chamber of the ICTY ultimately affirmed the Čelebici $i$ Trial Chamber's rulings on command responsibility,

232. Prosecutor v. Akayesu, Judgement, ICTR Trial Chamber, Case No. 1CTR-96-4-T (Sept. 2, 1998).

233. Id. at para. 489.

234. Prosecutor v. Delalić, Judgement, ICTY Trial Chamber, supra note 30, at paras. 386-89.

235. Id. at para. 386.

236. Id. at para. 387 .

237. Id. at para. $388-89$ (citations omitted).

238. Id. at para. 393 .

239. Id. In addition, the Trial Chamber rejected the defense's argument that causation was a necessary element of liability: "Notwithstanding the central place assumed by the principle of causation in criminal law, causation has not traditionally been postulated as a conditio sine qua non for the imposition of criminal liability on superiors for their failure to prevent or punish offences committed by their subordinates." Id. at para. 398. 
rejecting the notion that command responsibility was a form of strict liability or vicarious liability and holding that a commander is liable only if "information was available to him which would have put him on notice of offences." 240

While the Čelebici Appeals Chamber standard is now the definitive statement of ICTY and ICTR doctrine, ${ }^{241}$ there were several years when the doctrine was unsettled. Indeed, the most controversial application of command responsibility doctrine came in the years between the Celibici $i$ Trial and Appeals Chamber rulings. This application, in the Blaškić Trial Chamber judgement, brought back the Yamashita ghost of strict liability and provoked most of the recent critical writing on the doctrine.

Like Yamashita, the Blaškić case involved an ambiguous fact pattern in which widespread crimes occurred in the region under the commander's control, but where there was no direct evidence of the commander's knowledge of most of the crimes. In the face of this ambiguity, the Blaškic Trial Chamber diverged from the Čelebić $i$ Trial Chamber's analysis of the scope of the knowledge requirement, drawing from some of the post-World War II case law an affirmative duty on the part of commanders to investigate the conduct of their subordinates. ${ }^{242}$ Thus, the Blaškić Trial Chamber imposed something akin to a simple negligence standard: "taking into account his particular position of command and the circumstances prevailing at the time, such ignorance cannot be a defence where the absence of knowledge is the result of negligence in the discharge of his duties: this commander had reason to know within the meaning of the Statute." 243 The Trial Chamber found Blaškić guilty of a number of crimes using this interpretation of command responsibility doctrine, though in many instances the Trial Chamber also offered ambiguous alternative holdings. For example, on several counts the Trial Chamber concluded based on circumstantial evidence that Blaškić must have had actual knowledge of the likelihood of crimes, but also held in the alternative that "[i]n any case, General Blaškić did not perform his duties with the necessary reasonable diligence." 244

240. Čelebići Appeals Judgement, supra note 16, at para. 241.

241. See Blaškić Appeals Judgement, supra note 104, at para. 62.

242. Prosecutor v. Blaškić, Judgement, ICTY Trial Chamber, at para. 322, Case No. IT-95-14-T (Mar. 3, 2000).

243. Id. at para. 332.

244. Id. at para. 733; For other examples of confusing alternative holdings in the Blaškic Trial Judgement, see, e.g., paragraph 429 , which describes requirements for conviction under article $7(1)$, but suggests that "[b]y default, [Blaškić] could, however, be convicted on the basis of Article 7(3)." Similarly, paragraph 495 states that, "[i]n the final analysis, the Trial Chamber is convinced that General Blaškić ordered the attacks that gave rise to these crimes. In any event, it is clear that he never took any reasonable measure to prevent the crimes being committed or to punish those responsible for them." See also id. at para. 733 ("The Trial Chamber accordingly coneludes that General Blaškić did know of the circumstances and conditions under which the Muslims were detained in the facilities mentioned above. In any case, General Blaškic did not perform his duties with the necessary reasonable 
The Blaškić Trial Chamber decision triggered sharp criticism, prompting one commentator to argue that command responsibility doctrine was so insensitive to a defendant's "own personal culpability" that it had "no support in principles accepted by systems of national criminal law."245 In a dramatic reversal, in July 2004, the ICTY Appeals Chamber overturned the Trial Chamber's conviction of Blaškić on most counts, reducing his sentence from forty-five years to nine years. ${ }^{246}$ The sprawling 300-page opinion overturned many of the Trial Chamber's factual and legal holdings, but of greatest interest for present purposes was its forceful rejection of the Trial Chamber's negligence-based articulation of the command responsibility standard. The Appeals Chamber concluded that the Blaškić Trial Chamber's description of the doctrine was incorrect and that the "authoritative interpretation of the standard of 'had reason to know' shall remain the one given in the Čelebići Appeals Judgement."247 A few months earlier, the ICTR Appeals Chamber in Bagilishema had signaled similar discontent with the possibility of a negligence standard, noting that "[r]eferences to 'negligence' in the context of superior responsibility are likely to lead to confusion of thought ...."248 Thus, following the Blaškic and Bagilishema appeals judgements, the current state of the doctrine seems well-settled in the ICTY and ICTR, at least to the extent that something greater than ordinary negligence is required to trigger liability.

While these recent ICTY and ICTR decisions have finally brought some welcome clarity to the field, and should quiet much of the Yamashita-like criticism, it would be overly optimistic to suggest that the mens rea requirement will no longer generate debate and discussion. However neatly the standard is articulated, the application of that standard to widely varying fact patterns involving circumstantial evidence is likely to continue to prove controversial. Moreover, the ICC Statute employs slightly different language from the ICTY and ICTR Statutes, making it likely that ICTY and ICTR precedents will be carefully revisited by the ICC for consistency with its own statute. Where the ICTY and ICTR imposed liability on superiors who "knew or had reason to know" of crimes, the ICC Statute imposes liability on military commanders who "knew or, owing to the circumstances at the time, should have known" as well as civilian leaders who "knew, or consciously disregarded information which clearly indicated" that their subordinates were committing or were about to

\footnotetext{
diligence. ... Hence, the Trial Chamber is persuaded beyond all reasonable doubt that General Blaškić had reason to know that violations of international humanitarian law were being perpetrated ....").

245. Damaška, supra note 19 , at 456.

246. Blaškić Appeals Judgement, supra note 104, at 257-58.

247. Id. at paras. 62-64.

248. Prosecutor v. Bagilishema, Judgement (Reasons), ICTR Appeals Chamber, at para. 35, Case No. ICTR-95-1A-A (July 3, 2002).
} 
commit crimes. ${ }^{249}$ The first standard sounds less demanding and closer to negligence than does the current ICTY/ICTR formulation, while the second appears to impose the more stringent requirements of what some legal systems label advertent recklessness or dolus eventualis. ${ }^{250}$

\section{b. Superior-Subordinate Relationship Requirement}

The second component of command responsibility that has generated difficulty in application is the requirement of a superior-subordinate relationship. In current doctrine, the touchstone of such a relationship is "effective control": the material ability to prevent and punish the offenses. ${ }^{251}$ In recognition of the fact that in many modern conflict situations the de facto command structure on the ground may not be reflected in formal legal hierarchy, the commander need not have de jure authority over his ostensible subordinates, so long the requisite degree of effective control exists in fact. ${ }^{252}$ Indeed, even a civilian leader may be considered a superior for purposes of assigning liability under command responsibility. ${ }^{253}$ Extension of the doctrine to civilian leaders rests on the notion that, where such leaders exercise a level of control over subordinates comparable to that exercised by military commanders, ${ }^{254}$ the nominal distinction between a military hierarchy and some other sort of hierarchy (such as a police hierarchy) should not be dispositive. ${ }^{255}$

While the requirement of a superior-subordinate relationship is not conceptually controversial, it can create difficult evidentiary problems. In many conflict situations, there may be no clear evidence of a de jure hierarchy and it may be difficult to prove the scope of a defendant's effective de facto authority. For example, in the ICTY's Čelebici Judgement, two civilian defendants were acquitted of charges under the command responsibility doctrine because of insufficient proof that they exercised command authority over the perpetrators of crimes in the Čelibici prison camp. ${ }^{256}$ Zejnic Delalić was charged with command responsibility for crimes in the

249. ICC STATUTE, supra note 9, at art. 28.

250. For an explanation of these terms, see William A. Schabas, Mens Rea and the International Criminal Tribunal for the Former Yugoslavia, 37 NEw ENG. L. REv. 1015, 1032 (2003).

251. Čelebići Appeals Judgement, supra note 16, at para. 197.

252. Id. at paras. 192-93.

253. See, e.g., id. at paras. 195-96; Prosecutor v. Aleksovski, Judgement, ICTY Appeals Chamber, at para. 76, Case No. IT-95-14/1-A (Mar. 24, 2000); Prosecutor v. Musema, Judgement and Sentence, ICTR Trial Chamber, at para. 148, Case No. 1CTR-96-13-A (Jan. 27, 2000).

254. For the requirement that all superiors exhibit substantially similar powers of control, see Celebići Appeals Judgement, supra note 16, at para. 197.

255. Although the doctrine has not been found to include a causation requirement, the effective control requirement implicitly addresses the problem of causation: if one has the ability to prevent or punish the acts of subordinates, the failure to do so may be viewed as a causal factor in the commission of the crimes.

256. See Prosecutor v. Delalić, Judgement, ICTY Trial Chamber, supra note 30, at paras. 721, 810 , (Delalić is often referred to as Čelebići). 
camp on the grounds that he exercised authority over the camp in his role as coordinator of the Bosnian Muslim and Bosnian Croat forces in the area, and later as Commander of the First Tactical Group of the Bosnian army. ${ }^{257}$ However, the Trial Chamber ultimately concluded that the prosecution had failed to prove that Delalić had de jure or de facto control over the camp. ${ }^{258}$ Another defendant, Hazin Delic, was accused of being a deputy commander but was likewise acquitted of liability under Article 7(3) on the grounds that the prosecutor had not proved beyond a reasonable doubt that he was within the chain of command in the camp or that he had the power to control subordinates. ${ }^{259}$

If the Celebici $i$ camp case were prosecuted today, our intuition is that all the defendants would have been charged with participation in a Category Two JCE, and that the outcome of the case might have been different. In the Kvočka case a few years later, which dealt with crimes committed at the notorious Omarska prison camp, JCE-rather than command responsibility-was invoked as the main basis for liability. It was applied even for defendants alleged to be in positions of command, and the Trial Chamber's assessment of each defendant's precise role in the Omarska prison camp hierarchy was much less pivotal to the outcome of the case. ${ }^{260}$

Particular difficulties may also arise when a military commander with de jure control over troops claims that he has been unable to exercise such control due to circumstances beyond his control. ${ }^{261}$ According to the ICTY Appeals Chamber: "In general, the possession of de jure power in itself may not suffice for the finding of command responsibility if it does not manifest in effective control, although a court may presume that possession of such power prima facie results in effective control unless proof to the contrary is produced." 262 As with mens rea, the requirement of proof of effective control reflects a concern that a defendant's responsibility be properly aligned with his actual individual culpability.

IV

\section{Applying the Framework: Joint Criminal Enterprise and} COMMAND RESPONSIBILITY

We now turn to the framework of international criminal law we developed in Part I to assess both the doctrinal development and the use of joint criminal enterprise and command responsibility by international judges and prosecutors. We then offer suggestions for reform to these

\footnotetext{
257. Id. at paras. $4-5$.

258. Id. at paras. $720-21$.

259. Id. at para. 810 .

260. Kvočka Trial Judgement, supra note 101.

261. In such a situation, the commander will also often claim that he lacks the requisite mens rea, as discussed in the next section.

262. Čelebići Appeals Judgement, supra note 16, at para. 197.
} 
doctrines in light of the special features of international criminal law we set out in Part II.

\section{A. Joint Criminal Enterprise}

Joint criminal enterprise provides an example of an international criminal doctrinc where certain aspects of the human rights and transitional justice influcnces in international criminal law are in danger of overpowering the restraining force of the criminal law tradition. As currently formulated, the doctrine has the potential to stretch criminal liability to a point where the legitimacy of international criminal law will be threatenedthereby undermining not only the criminal law aims, but also the human rights and transitional justice goals of international criminal law.

\section{Influence of Human Rights}

The human rights paradigm appears to have been onc of the factors influencing the development of JCE in international criminal law, particularly its growth to include enterprises on the scale of the ethnic cleansing of an entire region. In its consideration of whether or not to recognize JCE liability, the Tadic Appeals Chamber found that an examination of the object and purpose of the ICTY Statute led it to conclude that the jurisdiction of the Tribunal should extend to "all those "responsible for serious violations of international humanitarian law' committed in the former Yugoslavia."263 From this conclusion, it further reasoned that "all those who have engaged in serious violations of international humanitarian law, whatever the manner in which they may have been perpetrated, or participated in the perpetration of those violations, must be brought to justice." 264 To fulfill this purpose, it elected to recognize JCE as implicitly falling within the jurisdiction of the Tribunal. ${ }^{265}$

In the view of the Appeals Chamber, then, the object and purpose of the ICTY Statute is to provide a criminal forum for the punishment of all those who have perpetrated especially serious violations of the victims' human rights, since all of the crimes within international criminal law constitute serious violations of international human rights law. Consonant with this objective, the international tribunals have sought to ensure that such violations are punished in the international forum, despite gaps in either the definitions of substantive crimes or in the liability provisions of the statute.

Human rights courts have frequently used thc idea of the object and purpose of the treaties they interpret to support an expansive interpretation of the rights articulated in those treaties. According to the "principle of effectiveness," human rights courts often seek to interpret rights guaranteed

263. Tadić V, supra note 28, at para. 189 (citing Article 7(1) of the ICTY sTATUTE, supra note 9).

264. Id. at para. 190.

265. Id. 
in treaties in ways that make those rights relevant to changing conditions or to ensure that they are practical and effective. ${ }^{266}$ The European Court of Human Rights, for example, has read implied rights into the European Convention on Human Rights to fulfill what it sees as the Convention's object and purpose of protecting individual rights. ${ }^{267} \mathrm{~A}$ former president of the European Court of Human Rights has noted that "the object and purpose of human rights treaties may often lead to a broader interpretation of individual rights ...."268 We view the 1CTY's willingness to read JCE into the 1CTY Statute as a manifestation of the principle of effectiveness, transposed into a criminal forum.

The history of JCE at the 1CTY, therefore, may be seen not only as an example of the victim-oriented cast of human rights law but also as borrowing some of human rights law's most important, and expansive, interpretive methodologies. As a practical matter, in the chaotic conditions in which war-time violations occur, and due to the post-war dislocation experienced by many victims, it is often very difficult to locate specific evidence proving that defendants have committed particular crimes. Joint criminal enterprise helps prosecutors secure convictions when such proof may be lacking. There is little explanation for the result in Tadic other than the Appeals Chamber's conviction that Tadic was guilty of killing the villagers in Jaskići despite the prosecution's inability to produce evidence of Tadić's participation-and, indeed, in spite of the Trial Chamber's conclusion that there was not enough evidence that the group in which Tadic acted had committed the killings.

Our conviction that the 1CTY Appeals Chamber's willingness to construe JCE broadly stems in part from the interpretive methodologies of human rights proceedings is reinforced by other examples from recent international criminal law jurisprudence. Trial Chambers at the ICTY and ICTR have used the teleological purpose of "protecting human dignity," for example, to broaden the definition of the crime of rape. ${ }^{269}$ In addition, other Chambers have embraced more expansive definitions of the crime of torture, which is not otherwise defined in the ICTY and ICTR statutes, than

266. See Laurence R. Helfer, Adjudicating Copyright Claims under the TRIPs Agreement: The Case for a European Human Rights Analogy, 39 HARV. INT'L L.J. 357, 403 (I998) (noting that the European Court of Human Rights interprets the European Convention on Human Rights in a manner that "satisf[ies] the European Convention's preeminent goal of protecting individual liberties"); MERRILLS, supra note 48 , at $78-81,98$.

267. MerRiLls, supra note 48 , at 77 .

268. Alexander Orakhelashvili, Restrictive Interpretation of Human Rights Treaties in the Recent Jurisprudence of the European Court of Human Rights, 14 EUR. J. INT'L L. 529, 534 (2003) (quoting Professor R. Bernhardt, a former President of the European Court of Human Rights).

269. William A. Schabas, Interpreting the Statutes of the Ad Hoc Tribunals, in MAN's InHumanity to Man: Essays on International LaW in Honour of Antonio Cassese 846, 865 (Lai Chand Vohrah et al. eds., 2003). 
that provided in the influential Convention Against Torture. ${ }^{270}$ That treaty limits the definition of the crime to acts committed for a list of proscribed purposes. At the ICTY and ICTR, several trial chambers have adopted this definition but have also unilaterally expanded its list of prohibited purposes. ${ }^{271}$ Another trial chamber rejeeted such a broader definition with explicit reference to the difference between the interpretive methodologies of criminal law and human rights law. It noted,

There may be a tendency, particularly in the field of human rights, towards the enlargement of the list of prohibited purposes, but the Trial Chamber must apply customary international humanitarian law as it finds it to have been at the time when the crimes charged were alleged to have been committed. In light of the principle of legality, the proposition that "the primary purpose of [humanitarian law] is to safeguard human dignity" is not sufficient to permit the court to introduce, as part of the mens rea, a new and additional prohibited purpose, which would in effect enlarge the scope of the criminal prohibition against torture beyond what it was at the time relevant to the indictment under consideration. ${ }^{272}$

By extending the liability theories of international criminal law through its recognition of JCE, the ICTY's Appeals Chamber helped ensure that individuals like Tadic could be convicted where direct proof of participation in particular crimes was lacking. This enhanced accountability, however, comes at the expense of key criminal law principles. As discussed in Part I, the culpability principle lies at the heart of the criminal law paradigm. In this view, individuals can only be punished for their individual choices to engage in wrongdoing. Furthermore, the scope of the wrongdoing attributable to the individual defendant must also be fairly attributable to his own acts.

Joint criminal enterprise, at least as currently formulated in international criminal law, poses significant challenges to the criminal law paradigm. The principal problem posed by JCE is the limited jurisprudence on

270. The Torture Convention defines torture as

any act by which severe pain or suffering, whether physical or mental, is intentionally inflicted on a person for such purposes as obtaining from him or a third person information or a confession, punishing him for an act he or a third person has committed or is suspected of having committed, or intimidating or cocrcing him or a third person, or for any reason based on discrimination of any kind, when such pain or suffering is inflicted by or at the instigation of or with the consent or acquiescence of a public official or other person acting in an official capacity. It does not include pain or suffering arising only from, inherent in or incidental to lawful sanctions.

U.N. High Commissioner for Human Rights, Convention Against Torture and Other Cruel, Inhuman or Degrading Treatment or Punishment, at art. 1(1), U.N. Doc. A/39/51 (1984).

271. See, e.g., Prosecutor v. Furundžija, Judgement, ICTY Trial Chamber, at para. 162, Case No. IT-95-17/1-T (Dec. 10, 1998) (expanding possible definition of torture to include humiliation of the victims, based on the Torture Convention's inclusion of "intimidation").

272. Prosecutor v. Kmojelac, Judgement, ICTY Trial Chamber, at para. 186, Case No. IT-97-25-T (Mar. 15, 2002). 
the relationship between an individual's potential criminal liability and the scope of the relevant enterprise. In Categories One and Two of a JCE, an individual may be convicted for any crime committed by any member of the enterprise within the scope of the JCE. In a Category Thrce JCE (or "extended" JCE), he may be convicted for any crime foreseeable as a consequence of the JCE, even though the crime was committed by someone else and he did not intend to commit such a crime. Of these three categories, Category Two is relatively unproblematic, because it applies only to "systems of ill-treatment" (typically concentration or prison camps), and the scope of the enterprise is generally limited to the camp itself. For Categories One and Three, however, the absence of any guidance at the ICTY and ICTR relating to how prosecutors should charge the scope of the relative enterprise is a matter of grave concern.

Depending on how broadly prosecutors describe the criminal goal of the enterprise in a JCE, or how loosely the judges construe foreseeability, an individual's liability can vary dramatically. What is the limit to intended or foreseeable wrongdoing in a country wracked by ethnic cleansing and armed conflict? As a practical matter, prosecutorial discretion appears to be the only meaningful limit on the extent of wrongdoing attributable to an individual defendant in JCE.

One Trial Chamber, for example, has stated that:

A joint criminal enterprise can exist whenever two or more people participate in a common criminal endeavor. This criminal endeavor can range anywhere along a continuum from two persons conspiring to rob a bank to the systematic slaughter of millions during a vast criminal regime comprising thousands of participants. ${ }^{273}$

Many JCEs, in fact, are described in expansive terms. The indictment of Milan Martic, for example, alleges that he was a participant in a JCE, the purpose of which was "the forcible removal of a majority of the Croat, Muslim and other non-Serb population from approximately one-third of the territory of the Republic of Croatia ... and large parts of the Republic of Bosnia and Herzegovina."274 Similarly, the indictments of severaI other individuals accuse them of participating in a JCE whose purpose was "the permanent forcible removal of Bosnian Muslims and Bosnian Croat inhabitants from the territory of the planned Serbian state."275 That these

273. Kvočka Trial Judgement, supra note 101, at para. 307.

274. Prosecutor v. Martić, ICTY Third Amended Indictment, at para. 4, Case No. IT-95-11 (July 14, 2003).

275. Prosecutor v. Stakić, ICTY Fourth Amended Indictment, at para. 26, Case No. IT-97-24-PT (Apr. 10, 2002); see also Prosecutor v. Milutinović, Decision on Dragoljub Ojdanic's Motion Challenging Jurisdiction-Joint Criminal Enterprise, ICTY Appeals Chamber, at para. 1, Case No. IT99-37-AR72 (May 21, 2003) (noting that the defendant is accused of participating in JCE, the purpose of which was "inter alia, the expulsion of a substantial portion of the Kosovo Albanian population from 
indictments have all been confirmed by a judge at the ICTY indicates that there is no systemic objection to allegations of JCEs of great breadth.

There appears to be no reason why the ICTR prosecution could not allege that the elimination of moderate Hutus and Tutsis in Rwanda was itself the object of a massive criminal enterprise. Through this charge, the prosecution could argue that each ICTR defendant who intentionally participated in the genocide and who foresaw the killings that occurred should be found liable for the murder of hundreds of thousands of people. At least one ICTR indictment alleges, for example, that the defendant "acting in concert with others, participated in the planning, preparation or execution of a common scheme, strategy, plan or campaign to exterminate the Tutsi and the political opposition to the Interim Government." ${ }^{276}$ Conservative estimates of the number of Tutsis killed in the genocide place the figure at over 500,000 victims. ${ }^{277}$

That international prosecutors have been alleging JCEs of nationwide scope is unsurprising. ${ }^{278}$ As the Appeals Chamber has imposed no limits on the quantum of contribution an individual must make to a particular JCE to be held liable for all crimes committed within its purview, there is no doctrinal reason why the prosecution should limit the scope of the JCE alleged. ${ }^{279}$ As the doctrine is currently formulated, however, and assuming the prosecution seeks to maximize its chances of conviction, then the broader the JCE alleged, the more likely it is that the defendant can be found guilty of making some contribution to its ultimate purpose. ${ }^{280}$

the territory of the province of Kosovo in an effort to ensure continued Serbian control over the province") (quoting the Third Amended Indictment in this case); Prosecutor v. Brdjanin, ICTY Fourth Amended Indictment, at para. 27.I, Case No. IT-99-36-PT (Dec. I0, 200 I).

276. Prosecutor v. Zigiranyirazo, ICTR Indictment, at para. 23, Case No. ICTR-2001-73-I (July 20, 200I).

277. Alison Des Forges, Leave None to tell the Story: Genocide in Rwanda I5-I6 (I999).

278. Nevertheless, some indictments do define the JCE relatively narrowly. The indictment of Miroslav Deronjić, for example, accuses him of participating in a JCE to effect "the permanent removal, by force or other means, of Bosnian Muslim inhabitants from the village of Glogova in the Municipality of Bratunac.” Prosecutor v. Deronjić, ICTY Second Amended lndictment, at para. 3, Case No. IT-02-61 (Sept. 29, 2004). Mitar Vasiljević was accused by the prosecution of participating in a JCE to "kill the Korimik group [of Muslims] in the burning of the house in Pionirska Street." Prosecutor v. Vasiljević, Judgement, ICTY Trial Chamber, supra note 32, at para. 167. Cases dealing with prison camps may limit the scope of the JCE to "persecut[ing] and subjugat[ing] non-Serb detainees" within the particular camp. See, e.g., Kvočka Trial Judgement, supra note 101, at para. 320.

279. Two Trial Chambers, however, have held in cases alleging Category Two JCEs, that the defendant's participation must be "significant," at least if the defendant is not a senior officer or leader. Kvočka Trial Judgement, supra note 101, at paras. 309, 311; Prosecutor v. Simić, Judgement, 1CTY Trial Chamber, at para. 28, Case No. IT-95-9-T (Oct. 17, 2003). In addition, one Trial Chamber has acquitted a defendant of charges based on a joint criminal enterprise because of the "extraordinarily broad nature" of the JCE alleged in that case. Prosecutor v. Brdanin, Judgement, ICTY Trial Chamber, at para. 355, Case No. IT-99-36-T (Sep. 1, 2004).

280. See, e.g., Prosecutor v. Brdanin, Decision on Form of Further Amended Indictment and Prosecution Application to Amend, ICTY Trial Chamber II, at paras. 8-11, Case No. IT-99-36 (June 
If the prosecution accuses an individual of participating in a JCE to remove all non-Serbs from Bosnia, for example, and the defendant has committed any crime that might amount to "ethnic cleansing," it is difficult to imagine how, under the ICTY's current interpretation of JCE, that individual could not be found guilty of all crimes committed in the context of this country-wide JCE, at least under a Category Three theory that all such crimes would be foreseeable, cven if not specifically intended. Members of the Bosnian Serb military could thus conceivably be held responsible for all of the crimes committed by the military if it can be shown both that they knew that the military was committing crimes and that they themselves engaged in some activity that amounts to "ethnic cleansing," and if they did not resign from the armed forces. Particularly since duress is not a defense to crimes under international criminal law, ${ }^{281}$ and the ICTY recognizes the state of "aiding and abetting" a JCE, which merely requires knowledge of the objectives of the JCE and intent to aid, it seems likely that any member of an armed force or paramilitary group that engages in widespread or widely-known criminal violations couId theoretically be held guilty for all crimes committed by that organization if that individual engages in any wrongdoing criminal under international criminal law, no matter how minor or isolated. ${ }^{282}$ While one might argue that this kind of liability is appropriate for leaders of such organizations, there is no doctrinal limitation in JCE that restricts its application to senior commanders or political leaders.

Joint criminal enterprise raises the specter of guilt by association and provides ammunition to those who doubt the rigor and impartiality of the international forum. If conspiracy is the darling of the U.S. prosecutor's nursery, ${ }^{283}$ then it is difficult to see how JCE can amount to anything less than the nuclear bomb of the international prosecutor's arsenal. ${ }^{284}$

\section{Responses to Critics}

We anticipate several rejoinders to our criticisms of JCE. Some scholars maintain that the application of the principle of individual culpability is inapposite to the context in which international crimes occur. Domestic criminal law scholars may argue that JCE merely represents a manifestation of the problems inherent even at the national level in doctrines like

26, 2001) ("The Trial Chamber draws the inference that the prosecution has [refused to disclose its case tol enable it to mould its case in a substantial way during the trial, according to how the evidence actually turns out.").

281. See, e.g., Prosecutor v. Erdemović, Judgement, ICTY Appeals Chamber, Case No. 1T-96-22A, at para. 19 (Oct. 7, 1997); Valerie Epps, The Soldier's Obligation to Die When Ordered to Shoot Civilians or Face Death Himself, 37 NEw ENG. L. Rev. 987 (2003).

282. Sassòli \& Olson, supra note 36 , at $754-55$.

283. Harrison v. United States, 7 F.2d 259, 263 (2d Cir. 1925).

284. See Schabas, supra note 250 , at 1032 (characterizing JCE as the "magic bullet" of the Office of the Prosecutor). 
complicity and conspiracy that address crime committed by groups. Finally, somc may believe that the objections we make to the overexpansiveness of JCE can be addressed at sentencing.

In response to the first point, it is true that international crimes, particularly those adjudicated in an international tribunal, occur against the backdrop of chaotic conditions: war, mass atrocity, and large-scale breakdown in public order. Determining an individual's criminal responsibility in such conditions is a daunting task, and one that critics of international justice have found to be poorly fulfilled. David Cohen, for example, argues that the World War II-era crimes of the Germans and Japanese, in contrast to ordinary crimes perpetrated by an individual or small group of people, were the intricate result of systematic action by "massive and complex organizations."285 "How then," Cohen asks, "is individual responsibility to be located, limited, and defined within the vast bureaucratic apparatuses that make possible the pulling of a trigger or the dropping of a gas canister in some far-flung place?"286 Michael Reisman argues that linking punishment to the voluntary decision to engage in wrongdoing does not map onto the morally ambiguous terrain in which international crimes are frequently committed:

In many of the most hideous international crimes, many of the individuals who are directly responsible operate within a cultural universe that inverts our morality and elevates their actions to the highest form of group, tribe, or national defense. After years or generations of acculturation to these views, the perpetrators may not have had the moral choice that is central to our notion of criminal responsibility. ${ }^{287}$

George Fletcher has also expressed concern for the model of individual criminal responsibility in societies that condone or perpetrate violations of international criminal law. ${ }^{288} \mathrm{He}$ argues that "if a nation bears guilt for the homicidal tendencies of its people, then individual perpetrators should arguably be less guilty and their punishment should be mitigated." 289

These critieisms highlight the difficulties of the international criminal prosecution. With the exception of George Fletcher's proposal, however,

285. David Cohen, Beyond Nuremberg: Individual Responsibility for War Crimes, in HuMAN Rights in Political Transitions: Getrysburg to Bosnia 53, 53 (Carla Hesse \& Robert Post eds., 1999).

286. Id.

287. W. Michael Reisman, Legal Responses to Genocide and Other Massive Violations of Human Rights, 4 LAW \& CONTEMP. Probs. 75, 77 (1996). For similar views, see Todd Howland \& William Calathes, The U.N.'s International Tribunal, Is It Justice or Jingoism for Rwanda? A Call for Transformation, 39 VA. J. INT'L L. I35, 158 (1998); Ruti Teitel, The Universal and the Particular in International Criminal Justice, 30 Colum. HuM. RTs. L. REv. 285, 296-98 (1999).

288. See generally George P. Fletcher, Romantics at War: Glory and Guilt in the Age OF TERRORISM (2002).

289. Id. at 158 . 
they do not provide an alternative model for assessing criminal responsibility once the decision to engage in international criminal trials of individual perpetrators has been made. While these critiques may present a powerful case for truth commissions or other forms of accountability, they provide no moral or practical resolution to the question of whether or not to imprison an individual - and how long the sentence should be-for his participation in mass atrocity. Once a criminal court like the ICTY, ICTR, or ICC has been established, the culpability principle is necessarily implicated. The alternative, after all, is some form of strict liability or collective punishment that would be fundamentally out of step with the moral and philosophical underpinnings of contemporary criminal justice. In addition, none of these proposals suggests that the moral justification for punishment in the international criminal system should be based primarily on a utilitarian justification for punishment. While many hope that international criminal law will in fact deter those who may be tempted to commit mass atrocities, we are aware of no scholar who has suggested that questions of individual responsibility in international criminal law should be resolved primarily on a utilitarian basis. In any event, we do not advocate such an approach. ${ }^{290}$

Criminal law scholars may make the opposite objection to our JCE analysis: not that the moral issues underlying this international liability theory are extraordinary, but that they are simply manifestations of familiar problems of domestic criminal law relating to complicity, conspiracy, and other criminal law doctrines targeted at group wrongdoing. ${ }^{291}$ Indeed, JCE is technically a form of complicity liability, which presents similar problems in well-established national criminal law systems. ${ }^{292}$

The U.S. Racketeer Influenced and Corrupt Organizations Act (RICO) perhaps best exemplifies both the difficulty of limiting collective responsibility and the erosion of the culpability principle in municipal criminal law. ${ }^{293}$ RICO does not criminalize any conduct not already criminalized under U.S. federal law, ${ }^{294}$ but instead makes it a crime to conduct a pattern

290. As we discuss later, however, we do believe that command responsibility can be partially justified on utilitarian grounds. See text accompanying notes 331-35.

291. See, e.g., Robert Weisberg, Reappraising Complicity, 4 BUfF. CRIM. L. Rev. 217, 220 (2000) (noting that accomplice liability is "one of the most troublesome subjects in criminal law"). Although the United States has, perhaps, loosened the strictures of the culpability principles more than other liberal criminal justice systems, other jurisdictions have begun enaeting statutes like RICO, which are targeted at the phenomenon of organized crime. Morgan Cloud, Organized Crime, RICO, and the European Union, 27 SYRACUSE J. INT'L L. \& CoM. 243 (2000). All criminal systems must punish concerted criminal activity; as Edward Wise notes, "Every system of law has had to grapple with the problem of defining the appropriate limits to doing so which derive from a common fund of basic ideas about what is entailed in designated conduct as criminal-the requirements of an act, of harm, or personal individual culpability." Wise, supra note 173, at 321 .

292. See SмIтH, supra note 137 , at 64 .

293. See 18 U.S.C. $\$ \S 1961-1968(2000)$.

294. Marcus, supra note 139 , at 15. 
of racketeering activity through involvement in an enterprise. ${ }^{295}$ It provides U.S. prosecutors with charging flexibility, various procedural benefits, and heightened sentences for individuals suspected of involvement in criminal enterprises. ${ }^{296}$ RICO also contains its own conspiracy provision, which some courts have interpreted as allowing for prosecutions in cases where traditional conspiracy law would preclude prosecution. ${ }^{297}$ RICO has been highly controversial, principally because of its expansive scope, vague language, and the general threat it poses to the weakening of the culpability principle. ${ }^{298}$ The United States has also enacted other statutes targeted at the dangers of group conduct, ${ }^{299}$ which, like JCE, seek to combat the harms produced by criminals acting in organized and semi-organized associations.

Judges interpreting group crimes like RICO and conspiracy, however, have imposed limits on their scope. In the United States, for example, the Supreme Court has held that prosecutors cannot charge individuals with participation in a single conspiracy when the facts demonstrate multiple conspiracies. ${ }^{300}$ The Supreme Court's reasoning in this area mirrors the concerns we have expressed about JCE. It has warned that conspiracy "is perhaps not greatly different from other [crimes] when the scheme charged is tight and the number involved small. But as it broadened to include more and more, in varying degrees to the confederation, the possibilities for miscarriage of justice to particular individuals become greater and greater." 301 Judges interpreting RICO, too, have placed limits on the scope of the enterprise covered by the crime. ${ }^{302}$

Furthermore, several U.S. courts have recognized that Pinkerton conspiracy, which closely resembles Category Three JCEs because both are predicated on foreseeable but unintended crimes, poses problems of fundamental fairness in cases where the link between an individual's

295. Susan W. Brenner, Of Complicity and Enterprise Criminality: Applying Pinkerton Liability to RICO Actions, 56 Mo. L. Rev. 931, 978-81 (1991).

296. See Gerard E. Lynch, RICO: The Crime of Being a Criminal, Parts I\& II, 87 Colum. L. REV. 661, 706 (1987).

297. LAFAVE, supra note 22, at 491. For an example of such an interpretation, see United States v. Elliott, 57I F.2d 880, 902 (5th Cir. 1978).

298. A leading U.S. criminal law textbook states that " $[\mathrm{t}]$ he R1CO statute has beeome one of the most controversial provisions in the federal criminal eode." KADISH \& SCHULHOLFER, supra note 174, at 732. For criticisms of RICO, see H.J. Inc v. Northwestern Bell Tel. Co., 492 U.S. 229, 255-56 (1989) (Scalia J., concurring) (suggesting RICO may be void for vagueness because it does not "possess the degree of certainty required for criminal laws."); Lynch, supra note 296, at 722.

299. See Susan W. Brenner, RICO, CCE, and Other Complex Crimes: The Transformation of American Criminal Law?, 2 WM. \& MARY BILl RTs. J. 239, 253-55 (1993) (discussing the Continuing Criminal Enterprise statute and the Continuing Financial Crimes Enterprise statute).

300. Kotteakos v. United States, 328 U.S. 750, 772-73 (1946).

301. Id. at 776 .

302. See, e.g., United States v. Bledsoe, 674 F.2d 647, 665 (8th Cir. 1982) (finding that the enterprise must "function as a continuing unit" and have an ascertainable strueture separate from that organization necessary to commit the erimes). 
wrongdoing and criminal liability is highly attenuated. ${ }^{303}$ The judges at the ICTY, by contrast, have not yet provided any elaboration on the definition of the term "enterprise" in JCE. Unlike domestic conspiracy theories, then, JCE lacks formal limitations and safeguards.

Finally, we address the contention that our objections to JCE can be resolved through sentencing determinations. It is true that the length of an individual's sentence could be calibrated to reflect the magnitude of his role in a JCE. The relationship between the various liability theories and the appropriate sentence, however, has long been murky in international criminal law. ${ }^{304}$ The ICTY Appeals Chamber only recently-eleven years after the inception of the Tribunal-concluded that "aiding and abetting is a form of responsibility which generally warrants a lower sentence than is appropriate to responsibility as a co-perpetrator." ${ }^{305}$ Beyond clarifying this distinction between aiding and abetting and perpetration, the Appeals Chamber has not explicitly stated that a sentence should reflect the individual's exact contribution to a JCE. Moreover, a defendant's ultimate sentence includes many factors other than the individual's role in the offense. Indeed, the gravity of the crime, and not the participation of the defendant, constitutes the "primary consideration" in sentencing at the ICTY. ${ }^{306}$ Other relevant considerations include the number of victims, the suffering of the victims, and the defendant's cooperation with the prosecution. ${ }^{307}$ In general, international sentencing practice remains largely indeterminate. ${ }^{308}$ Some have described the ICTY's sentences as "seemingly

303. See, e.g., United States v. Cherry, in which the court refused to extend Pinkerton to convictions of first-degree murder:

To extend substantive Pinkerton liability in the manner urged by the government would apparently render every minor drug distribution co-conspirator, regardless of knowledge, the extent of the conspiracy, its history of violence, and like factors, liable for first degree murder. Such a result appears incompatible with the due process limitations inherent in Pinkerton.

United States v. Cherry, 217 F.3d 811,818 (10th Cir. 2000).

In United States v. Alvarez the court observed:

We have not found, nor has the government cited, any authority for the proposition that all conspirators, regardless of individual culpability, may be held responsible under Pinkerton for reasonably foreseeable but originally unintended substantive crimes. Furthermore, we are mindful of the potential due process limitations on the Pinkerton doctrine in cases involving attenuated relationships between the conspirator and the substantive crime. (citations omitted).

United States v. Alvarez, 755 F.2d 830, 850 (11 th Cir. 1985).

304. Danner, supra note 96 , at $432-37$ (discussing the paucity of precedent in the imposition of criminal law sentences).

305. Prosecutor v. Vasiljević, Judgement, 1CTY Appeals Chamber, supra note 104, at para. 182.

306. Čelebici Appeals Judgement, supra note 16, at 731.

307. See, e.g., Prosecutor v. Ćešić, Sentencing Judgement, ICTY Trial Chamber, at paras. 31-32, 58-62, Case No. 1T-95-10/I-S (Mar. 11, 2004).

308. Drumbl, supra note 89. 
random." ${ }^{309}$ The open-ended and highly-discretionary nature of international criminal sentencing practice provides little assurance that, at least as it exists today, it will remediate the potential excesses of joint criminal enterprise.

Furthermore, correcting the overexpansive tendencies of JCE at the sentencing rather than the liability phase frustrates one of the transitional justice goals of international criminal trials: providing an accurate account of an individual's role in the relevant crimes. ICTY judges have rejected plea agreements negotiated between the Office of the Prosecutor and individual defendants because they believed the plea agreements did not capture accurately the defendant's role in crimes that occurred in the former Yugoslavia. ${ }^{310}$ While these episodes may partially be explained by the discomfort of civil law judges with guilty pleas, ${ }^{311}$ they may also be understood as vindicating the truth-telling function of the transitional trial.

\section{The Argument for a More Limited JCE}

Our claim in this Article is not that international judges have invented JCE liability from whole cloth and that, if they would only heed the teachings of domestic criminal law scholars, they could avoid the challenge to the culpability principle posed by JCE. On the contrary, questions about the proper scope of charged conspiracies and the definition of the organization in RICO continue to create significant doctrinal controversies in U.S. criminal law. ${ }^{312}$

Instead, we make the narrower claim that, when faced with decisions about how to limit the potential scope of JCE, international judges have almost invariably elected the most expansive interpretation of the doctrine. For example, they have decided to recognize Category Three JCEs, although they had little support for doing so from the World War II precedent and were faced with a significant number of domestic jurisdictions in which such liability is not allowed. Furthermore, they have not seriously grappled with the question of how to define limits on the scope of the JCEs

309. Rachel S. Taylor, Sentencing Guidelines Urged, INST. WAR PEACE ReP., Mar. 8, 2004, at http://www.iwpr.net/index.pl?archive/tri/tri_347_3_eng.txt.

310. See, e.g., Prosecutor v. Babić, Sentencing Judgement, ICTY Trial Chamber, at paras. 6-8, Case No. 1T-03-72-S (June 29, 2004). Babić initially pleaded guilty as an aider and abettor of a JCE. After the Trial Chamber "expressed doubts about the accuracy" of this level of responsibility, Babic pleaded guilty as a eo-perpetrator of a JCE. Id.

311. See Ana Uzelac, New Twist in Deronjić Trial, INST. WaR Peace ReP., Mar. 8, 2004, at http://www.iwpr.net/index.pl?archive/tri/tri_347_2_eng.txt.

312. Herbert Wechsler et al., The Treatment of Inchoate Crimes in the Model Penal Code of the American Law Institute: Attempt, Solicitation, and Conspiracy, 61 CoLum. L. REv. 957, 979 (1961) ("Much of the most perplexing litigation in conspiracy has been concerned less with the essential elements of the offense than with the scope to be accorded to a combination."); Note, Conspiracy: Statutory Reforn Since the Model Penal Code, 75 Colum. L. Rev. 1122, 1158 (1975) ("Ascertaining the dimensions of a criminal conspiracy, as to both parties and objectives, is perhaps the most complex and the most common of all the tasks presented by conspiraey litigation."). 
that a prosecutor may charge. They have permitted prosecutors to argue for conviction based on a JCE theory even where it was not alleged in the indictment, ${ }^{313}$ and they have allowed even the most extended forms of JCE to be used for the specific intent crimes of genocide and persecution. ${ }^{314}$

It is true that international criminal judges' willingness to cede much of the discretion of defining the scope of criminal wrongdoing in the case of JCEs to international prosecutors finds ample support in the practice of some municipal systems, particularly that of the United States. ${ }^{315}$ But, as we argued in Part II, the relatively new system of international criminal law cannot afford to operate with the same doctrinal and procedural freedom exhibited by a well-established domestic forum. Fifteen years ago, there existed no international institution enforcing international criminal law. After the first Gulf War, the suggestion by some that Saddam Hussein be subjected to an international trial was met with inaction. ${ }^{316}$ The landscape today has radically changed. International trials for Slobodan Milošević, Charles Taylor, Saddam Hussein, and other former heads of state, as well as hundreds of less well-known malefactors are either underway or under serious consideration.

Nevertheless, the legitimacy of international criminal law as a fair, impartial, and effective system of justice is far from secure. Over-expansive doctrines, unbridled prosecutorial discretion, and unpersuasive judicial decisionmaking may still doom international criminal adjudication. As Judge Hunt of the ICTY recently opined in dissent from a procedural ruling on the admissibility of written witness statements, "[ $t$ ]his Tribunal will not be judged by the number of convictions which it enters . . . but by the fairness of its trials." 317 Judge Hunt warned that decisions giving short shrift to the "rights of the accused will leave a spreading stain on this Tribunal's reputation." "318 In this same spirit of strong support for the aims of international criminal law but concern for its future, we

313. The ICTY Appeals Chamber, however, recently held that this practice should not be permitted. Blaškić Appeals Judgement, supra note 104, at para. 215.

314. Prosecutor v. Milošević, Decision on Motion for Judgement of Acquittal, ICTY Trial Chamber, at para. 291, Case No. IT-02-54-T (June 16, 2004); Prosecutor v. Brdjanin, Decision on Interlocutory Appeal, ICTY Appeals Chamber, at para. 9, Case No. IT-99-36-A (Mar. 19, 2004) (stating "provided that the standard applicable to that head of liability, i.e. 'reasonably foreseeable and natural consequences' is established, criminal liability can attach to an accused for any crime that falls outside of an agreed upon joint criminal enterprise").

315. Peter Krug, Prosecutorial Discretion and Its Limits, 50 AM. J. CoMP. L. 643, 643 (2002) (describing U.S. prosecutors as acting with "broad, generally unregulated discretion" and noting that "the scope of prosecutorial discretion has steadily expanded in recent decades").

316. EC Wants Saddam on Trial for War Crimes, Genocide, Wall Sr. J., Apr. 16, 1991, at AI6; Lawyers Ask Trial of Hussein Before War Crimes Tribunal, N.Y. TimEs, June 6, 1991, at A9.

317. Prosecutor v. Milošević, Dissenting Opinion of Judgc David Hunt on Admissibility of Evidence in Chief in the Form of Written Statements, ICTY Appeals Chamber, at para. 22, Case. No. IT-02-54-AR73.4 (Oct. 2I, 2003).

318. Id. 
believe that JCE should be narrowed. Our specific suggestions for reform are provided in Part $\mathrm{C}$ of this section.

The debate over how to define the doctrines of JCE and command responsibility does not reduce to a binary choice between the expansive tendencies of human rights interpretation and the narrowing impulse of the criminal law paradigm. The influence of the transitional trial has also left an important mark on the development of these liability theories. In particular, both international prosecutors and judges have struggled with how to capture accurately the role an individual played either in the crimes at issue in a particular trial or, more frequently, in the context of the crimes committed in the relevant region or country. The case of Radislav Krstić, discussed below, reveals these difficulties.

As described in Part I, a focus on prosecuting the senior political leadership is a distinguishing hallmark of the transitional trial. JCE is arguably at its most useful for international prosecutors when it comes to high-level perpetrators. In a brief to the Appeals Chamber, the prosecution argued that one of the aims of the Tadic Appeal Judgement in recognizing JCE was "to extend responsibility as co-perpetrators of a crime to those who, situated at the highest echelons of power, were removed from the actual perpetration of the offence, but had been deeply involved in its organisation and execution." 319 The desire to describe political or military leaders as perpetrators of joint criminal enterprises owes much to the didactic and political functions of the Tribunals described in the transitional justice literature.

The Milošević case, featuring three indictments that charge him with participating in three separate JCEs to remove non-Serbs from Croatia, ${ }^{320}$ Bosnia and Herzegovina, ${ }^{321}$ and Kosovo ${ }^{322}$ respectively, is a particularly salient example of how JCE may be used to reach high-level perpetrators. The Bosnian indictment accuses Milošević of participating in a JCE, whose purpose "was the forcible and permanent removal of the majority of nonSerbs, principally Bosnian Muslims and Bosnian Croats, from large areas

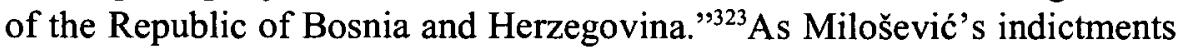
suggest, international criminal prosecutors appear to be attempting to fit as

319. Prosecutor v. Krnojelac, ICTY Appeal Brief of the Prosecution at para. 2.19, Case No. IT-9725-A (Aug. 22, 2002).

320. Prosecutor v. Milošević, ICTY First Amended Indictment, at para. 6, Case No. 1T-02-54-T (Oct. 23, 2002).

321. Prosecutor v. Milošević, ICTY Initial Indictment, at para. 6, Case No. IT-01-51-1 (Nov. 22, 2001).

322. Prosecutor v. Milošević, ICTY Second Amended lndictment, at para. I6, Case No. IT-99-37PT (Oct. 16, 2001).

323. Prosecutor v. Milošević, ICTY Initial Indictment, at para. 6, Case No. IT-01-51-1 (Nov. 22, 2001). The indictment also clarifies that the word "committed" was not intended to suggest that Milošević personally committed any of the charged crimes, but instead to refer to his participation in a JCE. Id. at para. 5. 
many political and military leaders under the JCE framework in preference to command responsibility liability, even in cases where the latter arguably better describes the actions of the accused.

There is a clear symbolic dimension to convicting a defendant for having participated in a JCE. In a doctrinally unimportant but psychologically critical move, "joint criminal enterprise" sounds more serious than simply alleging that someone participated in a "common plan" or has been found liable on a complicity theory. We suspect that the increasing use of the label "joint criminal enterprise" by international prosecutors in lieu of "common plan" owes much to the rhetorical weightiness of the former term. Certainly, press releases about indictments prominently feature the allegation that an individual participated in a "joint criminal enterprise." More substantively, JCE allows the prosecution and judges to capture the seriousness of a leader's responsibility for the violent course of events.

It is, perhaps, not coincidental that one of the major justifications for the criminal organizations charge at Nuremberg also lay in the didactic function of that Tribunal. Condemnation of the principal Nazi structures was seen by the architects of the trial to carry "a clear message that organized criminality represented not an aberration, but rather reflected a deep current in German national life." ${ }^{325}$ In this way, the use of criminal organizations reflected the Nuremberg Tribunal's use as a transitional trial, educating the German public about the iniquity of their recent history. While JCE itself has no such broad didactic function, it is being used by international prosecutors as a vehicle for demonstrating the criminality of the senior leadership. Interestingly, one scholar maintains that JCE weakens the didactic function of international courts because, at least in its extended form, it lowers the relevant mens rea required to secure convictions. William Schabas argues that "[i]f it cannot be established that leaders such as Milošević actually intended the atrocities with which they are charged, the door is left ajar for future generations to deny the truth." ${ }^{326}$

While we believe that this argument has merit, we note that in the cases of senior leaders, the tensions with the criminal law paradigm become less acute. Most agree that the international forum should be reserved

324. The press release for a recent indictment, for example, contains four headings: "the accused," "joint criminal enterprise," "factual allegations," and "the charges." Press Release, ICTY, Jovica Stanisic and Franko Simatovic Indicted by the ICTY for Crimes Against Humanity and War Crimes (May 6, 2003), at http:/www.un.org/icty/latest/index.htm. One wonders why the press office felt it necessary to separately list JCE when the heading, "the charges," is sufficient to encompass JCE charges. Similarly, it seems highly unlikely that a press release would prominently feature a heading called "complicity," if that were the term of art used in international criminal law. "Complicity" simply does not have the dramatic (and dangerous) ring of "joint criminal enterprise."

325. Pomorski, supra note 155 , at $247-48$.

326. Schabas, supra note 250 , at 1034. 
for senior leaders. ${ }^{327}$ In addition, it appears less unjust to charge a leader with a broad JCE that he arguably set into motion than it is to charge a mid- or low-level participant in a similar way. Thus, the philosophical conflicts explored above with regard to criminal law, which could be quite severe if a mid- or low-level perpetrator were held responsible for a broad range of crimes, are attenuated in the case of the transitional trial focused on the political leadership.

Despite the suitability of JCE for cases involving political and military leaders, there is currently no formal limitation on JCE that restricts its application to those whose position might morally justify the deployment of this powerful doctrinal weapon. As Tadić's case demonstrates, JCE can just as easily be used to increase the likelihood of convicting a "small fish" as it can be used to land the biggest shark. As described in Part IV.C, the most important doctrinal change to joint criminal enterprise we suggest seeks to ensure that this theory remains useful against those who instigate and plan mass atrocities without ensnaring low-level perpetrators for the full scope of wrongdoing that may have occurred and over which they had little control.

In the development of JCE doctrine, concern for symbolic vindication of violations of victims' human rights has proven a more potent influence than worries over potential violations of defendants' rights. More importantly, the victim-oriented, civil law model of human rights has diverted attention from the values vindicated by the criminal law-oriented culpability principle. We are concerned that this expansive orientation dispenses too quickly with the protections of the criminal law that seek to ensure that an individual is convicted for his own deliberate wrongdoing. In our view, strict adherence to the criminal law culpability principle is the way to enhance the perceived legitimacy of international criminal trials and thereby the overall effectiveness of such trials in achieving human rights and transitional justice goals.

\section{B. Command Responsibility}

Although in our view the judges of the ICTY have not struck the proper balance among the criminal law, human rights, and transitional justice influences in international criminal law with respect to joint criminal enterprise, they have been more successful with command responsibility. They have reined in overexpansion of the doctrine and have kept it tethered more closely to the culpability principle. The ICTY Office of the Prosecutor, however, has increasingly relied on JCE in preference to command responsibility. We believe that, with this shift, some of the

327. See Drumbl, supra note 89 (describing the "prosecutorial focus" on political and military leaders). 
advantages of command responsibility liability as a tool of transitional justice have been lost.

The recent command responsibility jurisprudence at the ICTY and ICTR has strengthened the culpability principle in international criminal law. In its more expansive guise, command responsibility, like JCE, has the potential to push the boundaries of the traditional criminal law paradigm, particularly with respect to the mens rea and culpability principles that are central to criminal law. In general, offenses committed with a high level of intent or purposefulness are viewed as more serious and morally blameworthy than offenses committed recklessly or negligently. ${ }^{328}$ Strict liability, where the defendant need have no particularly blameworthy mental state, is rare and disfavored in criminal law; it most often appears in regulatory offenses for which no particular moral stigma attaches. ${ }^{329}$ Considering the seriousness of the crimes tried in international tribunals, it is understandable that there has been considerable debate about the lower bounds of mens rea for command responsibility. ${ }^{330}$ The fact that defendants are held liable for their omissions rather than for their acts, the lack of a causation requirement, and the lowered mens rea-particularly imposition of liability without actual knowledge of the crimes by subordinates based on recklessness, and perhaps even negligence in failing to investigate-all represent departures from normal criminal law principles. With the Blaškić and Bagilishema decisions, the ICTY and ICTR Appeals Chambers have repudiated the drift of the doctrine toward a negligence standard and, in doing so, have vindicated the importance of individual culpability.

Command responsibility also illuminates two aspects of international criminal law we have thus far not focused on in this Article: the roots of international criminal law in the law of war and the deterrent value of the criminal sanction. The criminal law tradition presented in Part I, with its emphasis on wrongdoing and culpability, most closely resembles the classic retributive model of criminal punishment. Command responsibility, by contrast, includes the important element of deterrence, a goal shared by both criminal law and human rights law.

The deterrent value of the international criminal law system as a whole is highly contentious. ${ }^{331}$ While advocates of international eriminal accountability confidently extoll its deterrent potential, many doubt whether international criminal law in fact has the potential to deter future

328. David Luban, Contrived Ignorance, 87 GEo. L.J. 957, 960 (1999).

329. Morissette v. United States, 342 U.S. 246, 254 (1952). The Canadian Supreme Court, for example, has deemed strict liability offenses punishable by terms of imprisonment to be unconstitutional. See Reference Re Section 94(2) of the Motor Vehicle Act, 69 B.C.L.R. 145 (1985).

330. Damaška, supra note 219, at 456; see also, e.g., Yuval Shany \& Keren R. Michaeli, The Case Against Ariel Sharon: Revisiting the Doctrine of Command Responsibility, 34 N.Y.U. J. INT'L L. \& PoL. 797 (2002) (discussing lower bounds of command responsibility).

331. See generally Tallgren, supra note 15. 
opportunistic political leaders, who will unscrupulously foster ethnic and religious enmity to secure their own political ambitions despite the threat of a possible future prosecution if they fall from power. There is more hope, however, that the well-established law of war, which is enforced through international as well as domestic mechanisms, may, in fact, restrain professional militaries from engaging in (or tacitly condoning) large-scale war crimes.

Command responsibility has been recognized in the law of war at least since the Hague Conventions of $1907 . .^{332}$ Unlike a JCE, where the enterprise itself is usually formed with criminal aims in mind, the command and control structure at the heart of command responsibility doctrine typically exists within a professional military that recognizes and enforces legal limits on its conduct. ${ }^{333}$ Furthermore, liability for command responsibility is predicated on the failure to prevent or punish criminal violations committed by others. Thus, deterrence of criminal violations lies at the heart of the doctrine. Even if international criminal law prosecutions themselves have little deterrent value, the command structure embodied in the liability of command responsibility certainly does. ${ }^{334}$ This focus on systemic deterrence reflects the goals both of general deterrence in criminal law theory and in human rights law.

From the pragmatic perspective of encouraging compliance with certain standards of conduct, a focus on high-level leaders has natural advantages. Superior officials, as long as they actually have control over their subordinates, are in a better position to identify the relevant standard of conduct and impose it across the board. ${ }^{335}$ In law and economics terms, they are least-cost avoiders. Moreover, in a moral sense, high-level government officials and military leaders are not like everybody else; they have affirmative obligations related to the governance of society, such as monitoring persons under their control to ensure that they comply with certain standards of conduct. For culpability purposes, the relevant moment of moral choice for a leader is not necessarily the moment when the crimes are committed, but when he assumes a position of authority over others and fails to monitor his subordinates.

Like JCE, command responsibility may also help fulfill the expressive functions of transitional justice. Indeed, command responsibility also comes into greater focus and its virtues become more apparent when

332. See Hague Convention (IV), supra note 9, at art. 1 .

333. Indeed, the ability to enforce the laws of war through a command structure is one of the preconditions for combatant immunity from prosecution for murder for killings in the course of armed conflict. See id.

334. As the U.S. Supreme Court observed, "the law of war presupposes that its violation is to be avoided through the control of the operations of war by commanders who are to some extent responsible for their subordinates." In re Yamashita, 327 U.S. 1, 15 (1946).

335. Id. 
viewed through this lens. The doctrine seems tailor-made for transitional justice, which focuses on high-level perpetrators and equates them with the prior, rights-abusing regime. The legitimacy of a government in the modern era depends in large measure on its willingness and ability to respect human rights norms. A regime in which superior officials have failed to fulfill that role is one that the transitional justice paradigm seeks to delegitimize.

Command responsibility doctrine also serves the purpose of attributing responsibility to some individuals so that the rest of society can move on. When there are too many low-level perpetrators to put them all on trial, it makes sense to focus on the high-level officials who had the ability to affect policy and to control the criminal activity of low-level perpetrators. While JCE also fulfills this purpose, command responsibility may be critical to securing convictions of high-level officials when there is little proof of those individuals' direct involvement in the crimes or intent to further a criminal enterprise. We discuss this aspect of command responsibility further in Part V, in conjunction with the Abu Ghraib prison scandal.

We cannot fully explain why the development of command responsibility bears few traces of the more expansive tendencies of the human rights model currently evident in JCE. We suspect that the vivid memory and vociferous criticism of the Yamashita decision have made judges less willing to expand the bounds of command responsibility in the way they have with JCE. Perhaps because of the long tradition and systemic nature of command responsibility, judges perceive that the human rights goals of deterrence are adequately served by the doctrinc even with its more stringent mens rea requirements. Joint criminal enterprise has also offered international prosecutors and judges a method of liability that has allowed them to secure convictions of individuals without distorting command responsibility. Finally, and most cynically, judges may be concerned that a command responsibility doctrine that allows liability for negligence would be more likely to be applied against Western leaders than would JCE doctrine, which requires as a threshold the intentional decision to aid a criminal enterprise. Whether or not these speculations prove accurate, command responsibility illustrates that the three influences that form our framework of international criminal law vary in their intensity by the particular demands and historical context of each doctrine, as well as its relationship to other aspects of international criminal law.

\section{Suggestions for Reform}

Application of our framework for international criminal law uncovers areas of reform for the two liability doctrines. We suggest that international judges should ensure that JCE adheres more closely to the criminal law culpability principle, that command responsibility continue to do so, and 
that international prosecutors should not forego command responsibility in preference to JCE. These shifts in law and practice will enhance the legitimacy of the international criminal trials and better instantiate the goals of the human rights and the transitional justice models.

\section{JCE: Requiring a Substantial Contribution}

The ICTY judges have given up too much control to international prosecutors in their endorsement of the current status of JCE doctrine. They should require that prosecutors tie the conduct of individuals more tightly to the scope of criminality encompassed by the enterprise alleged. Nevertheless, formulating a uniform rule for the proper scope of JCEs is both futile and unwise.

Some individuals, particularly senior political or military figures, may justly be charged with wrongdoing that encompasses atrocities committed over several years and throughout a particular region. For this reason, we do not recommend jettisoning Category Three of JCE. These kinds of JCEs play an important role in international criminal law, even, in some cases, for low-level perpetrators. It is hardly unjust to hold Tadić responsible for murders committed in his presence as part of a frenzy of ethnic cleansing in which he actively participated. Holding Tadić liable, however, for all the crimes visited upon Bosnian Muslims in the early I990s would seem patently unjust. Although no convictions representing such a gross extension of liability have yet been entered, leaving that possibility doctrinally open and relying solely on prosecutorial and judicial discretion to avoid it needlessly renders the international criminal system vulnerable to abuse.

Instead of seeking to restrict the scope of enterprises in an across-theboard fashion, the judges should require that prosecutors prove that the defendant has made a substantial contribution to the JCE charged. Such a requirement would both restrict the scope of the JCE the prosecution is able to charge and would help ensure that JCE is used primarily for senior leaders. At the very least, such a requirement will avoid the unsavory possibility of the prosecution proving a low-level defendant's contribution to a JCE defined as all the crimes occurring within a country over a multi-year period-a situation possible under the current articulation of the rules.

Some ICTY Trial Chambers have already embraced this idea by requiring prosecutors to prove that the defendant made a "significant" contribution to the enterprise. In the Kvočka case, one Trial Chamber identified this requirement and articulated a series of factors that should be considered when assessing whether an individual's participation in a JCE is "significant":

The level of participation attributed to the accused and whether that participation is deemed significant will depend on a variety of factors, including the size of the criminal enterprise, the functions 
performed, the position of the accused...the seriousness and scope of the crimes committed and the efficiency, zealousness or gratuitous cruelty exhibited in performing the actor's function.... Perhaps the most important factor to examine is the role the accused played vis-à-vis the seriousness and scope of the crimes committed. . $^{336}$

These factors should guide prosecutors and Trial Chambers in their assessment of whether an individual has indeed made a substantial contribution to the JCE alleged in the indictment.

\section{Specific Intent Crimes}

In addition, liability under Category Three JCEs should not be permitted for the specific intent crimes of genocide and persecution. Similar caution should be used in holding defendants liable under a theory of command responsibility for such crimes, absent proof that the defendant knew or had reason to know the subordinates were committing those particular crimes. The ICTY and ICTR have made it clear that the most salient feature of these crimes, and the source of the enhanced stigma associated with them, is their elevated mens rea. ${ }^{337}$ This distinctive feature of these serious crimes is weakened by the lowering of the mental state to recklessness or negligence, as would occur in a Category Three JCE or under the looser versions of command responsibility.

\section{The Relationship Between JCE and Command Responsibility}

In contrast to JCE, command responsibility doctrine does not call for significant doctrinal reform in light of the Appeals Chambers' decisions in Bagilishema and Blaškić that command responsibility requires something akin to reckless, rather than negligent, disregard of information about the commission of crimes by subordinates. Instead of recommending reform of command responsibility, we call for its greater employment by international prosecutors. Command responsibility remains a uscful doctrine that should not be discarded by prosecutors and Trial Chambers attracted by the more lenient proof requirements, or dramatic tenor, of a JCE conviction. As discussed above, command responsibility promises the possibility of greater deterrence of future violations. It allows for a focus on senior leaders in a way that accords with the expressive function of transitional justice, and it poses less of a challenge to the culpability principle than does an unchecked JCE doctrine.

336. Kvočka Trial Judgement, supra note 101, at para. 311.

337. Krstić Appeals Judgement, supra note 105, at para. 134 ("Genocide is one of the worst crimes known to humankind, and its gravity is reflected in the stringent requirement of specific intent."). 
As a practical matter, prosecutors employ JCE and command responsibility theories when direct proof of a defendant's involvement in particular crimes is lacking. For crimes in which there is no indication that an accused played a direct part, command responsibility doctrine may capture more accurately the true linchpin of the individual's guilt: the violation of a duty, based on his position of authority, to prevent such crimes. Although international judges have not analyzed the relationship between command responsibility and JCE in this way, we believe that judges' discomfort with prosecutorial decisions that advance theories of direct responsibility (including JCE) rather than command responsibility is at work in some recent cases. For example, we believe it helps explain the Appeals Chamber's dramatic decision in the case of Radislav Krstic.

Krstic was the commander" ${ }^{338}$ of the "Drina Corps" of the Bosnian Serb army. The Drina Corps was formally responsible for the area of Bosnia that included the town of Srebrenica during the massacre of approximately seven thousand Bosnian men and boys in July $1995 .^{339}$ Krstić's role in the Srebrenica killings, however, was complicated by the fact that the killings appear to have been orchestrated by General Mladić, the Commander of the Bosnian Serb Army, and carried out largely by forces which Krstić did not command, including members of the military police.

On the basis of the evidence it heard at trial, the Trial Chamber convicted Krstic of genocide for the massacres at Srebrenica under a theory of JCE. ${ }^{340}$ While acknowledging that Krstic appeared to be a serious career officer who would not have instigated a genocidal plot of his own accord and who did not personally participate in any of the killings, the Trial Chamber also found that Krstić had knowingly and intentionally provided support to the criminal enterprise in carrying out the genocide, and therefore that he was guilty as a co-perpetrator in the JCE.

The Appeals Chamber overturned thc Trial Chamber's factual finding that Krstic intended to participate in a JCE to commit genocide. In the Appeals Chamber's view, the main evidence at trial tying Krstic to the killings was his knowledge of Mladić's intention to execute the Bosnian Muslims of Srebrenica and his knowledge that Drina personnel were used

338. At trial, General Krstic had argued that he did not assume control of the Drina Corps until July 20, 1995. Id. at para. 45. The killings in Srebrenica occurred in mid-July 1995. The Trial Chamber found that Krstić assumed de facto command of the Drina Corps as of July 13, 1995. Id. at paras. 32831,625. The Appeals Chamber did not disturb this finding on appeal. Id. at para. 47.

339. Id. at para. 2.

340. Professor Martinez was an associate legal officer in the Trial Chamber that rendered the Krstic decision during a portion of Krstić's trial. This section of the Article is not meant to reflect or comment upon the merits of the case as a whole or upon the Trial Chamber decision. Instead, our observations are limited to an analysis of the impulses that seem to have motivated the Appeals Chamber decision, in which Professor Martinez did not participate in any way. 
to carry out that intention. ${ }^{341}$ It found that "the criminal liability of Krstic is thcrefore more properly expressed as that of an aider and abettor to genocide, and not as that of a perpetrator. ${ }^{342}$

Given the inability of any judge, trial or appellate, to peer into General Krstić's heart, it is hard to understand the Appeals Chamber's reversal, on a cold record, of a Trial Chamber's factual finding about mens rea that was entered after a year of live, in-court testimony, including from the defendant himself. We do not view the Appeals Chamber's decision ultimately as a disagreement with the Trial Chamber or the prosecution about the meaning of individual pieces of ambiguous evidence. Rather, we understand the decision as driven by the Appeals Chamber's obvious discomfort with a theory of liability that led to Krstićs conviction as an equal co-perpetrator in the genocidal JCE at Srebrcnica, when it was clear that he played a less culpable role in the massacres than many other individuals who werc not in custody, including General Mladić.

For unknown reasons, instead of placing limits on JCE doctrine or addressing the difference in Krstic's culpability through reducing his sentence (as, in fact, the Trial Chamber had done), the Appeals Chamber chose to upend the verdict on factual grounds. Given the Appeals Chamber's obvious discomfort with the broad liability Krstic incurred under a JCE theory, it is even more curious why the court concluded that Krstić's conduct amounted to aiding and abetting the JCE when it could have recast his liability on a command responsibility theory, which had been included in his indictment. Since the Appeals Chamber viewed General Krstićs principal fault as failing to take steps to prevent troops under his command from participating in the genocidal plan hatched by others, command responsibility-rather than aiding and abetting-secms to capture more accurately the basis for the liability that the Appeals Chamber found..$^{343}$ In short, given its decision to reduce both the degree of Krstić's liability and his sentence from forty-five to thirty-five years, ${ }^{344}$ we believc that a legal analysis of the relationship between JCE and command responsibility - rather than a reversal of the Trial Chamber's factual findings - would have better responded to thc Appeals Chamber's concerns and would have provided an important signal for prosecutorial strategy in future cases.

341. Krstić Appeals Judgement, supra note 105, at para. 134.

342. Id. at para. 137.

343. We should note that we do not mean to endorse the Appeals Chamber's overturning of the Trial Chamber's factual findings regarding General Krstić's intent to aid the genocidal plan, nor to suggest that the Trial Chamber's conclusions of law, given its factual findings, were incorrect. Indeed, we view with some skepticism the Appeals Chamber's recent propensity to ovcrtum the Trial Chamber's factual findings. Rather, we simply intend to comment on the appropriate legal categorization, based on the Appeals Chamber's factual findings.

344. Krstić Appeals Judgement, supra note 105, at para. 268. 
More fundamentally, regardless of whether we may disagree with particular aspects of the decision, we view the Krstic decision as reflecting the ICTY Appeals Chamber's vindication of the culpability principle by calibrating a defendant's individual actions and intent with his liability. Indeed, the Appeals Chamber's willingness to overturn the Trial Chamber findings in fairly dramatic fashion to achieve that balance indicates the degree to which the Tribunal itself views adherence to the culpability principle as essential to its legitimacy and the success of its overall mission.

\section{$\mathrm{V}$}

The Future of Joint Criminal ENTERPrise ANd CoMmand RESPONSIBILITY IN INTERNATIONAL AND DOMESTIC ADJUDICATION

\section{A. Other International Courts}

\section{The Continuing Vitality of Joint Criminal Enterprise}

Every international criminal court or tribunal established since the founding of the ICTY and ICTR has incorporated both command responsibility and a version of JCE into their jurisprudence, either formally as a matter of statutory law or informally as a matter of prosecutorial policy. The Rome Statute of the International Criminal Court (ICC) states that an individual is criminally responsible for a crime if he commits, orders, or aids and abets the crime, or "[i]n any other way contributes to the commission or attempted commission of such a crime by a group of persons acting with a common purpose." ${ }^{345}$ Thus, JCE, under one of its alternative names (common purpose doctrine), falls within the ambit of the ICC Statute.

This feature of the ICC Statute does not derive from the JCE jurisprudence of the ICTY, which postdates the negotiation of the ICC Statute, but instead from language borrowed from the International Convention for the Suppression of Terrorist Bombings. ${ }^{346}$ The ICC prosecutor has not yet

345. ICC STATUTE, supra note 9, at art. 25. This provision continues:

Such contribution shall be intentional and shall either: (i) Be made with the aim of furthering the criminal activity or criminal purpose of the group, where such activity or purpose involves the commission of a crime within the jurisdiction of the Court; or (ii) Be made in the knowledge of the intention of the group to commit the crime. ld.

346. Kai Ambos, Article 25: Individual Criminal Responsibility, in COMMENTARY ON THE ROME Statute of the International Criminal Court: Observers' Notes, Article by Article 475, 483 (Otto Triffterer ed., 1999). Article 2 of this Convention reads in part:

Any person commits an offence within the meaning of this Convention if that person unlawfully and intentionally delivers, places, discharges or detonates an explosive or other lethal device in, into or against a place of public use, a State or government facility, a public transportation system or an infrastructure facility ... . [Or] [i]n any other way contributes to the commission of one or more offences as set forth in paragraph $l$ or 2 by a group of persons acting with a common purpose; such contribution shall be intentional and either be made with the aim of furthering the general criminal activity or purpose of the group or be made in the knowledge of the intention of the group to commit the offence or offences concerned. 
issued any indictments, and it is too soon to tell what use, if any, he will make of the doctrine of JCE as it has been developed by the ICTY. If the indictments of the Special Court for Sierra Leone and East Timor's Special Panel for Serious Crimes provide any indication, however, the ICC prosecutor will likely employ this theory liberally.

The Statute of the Special Court for Sierra Leone closely tracks the provision on individual criminal responsibility contained in the ICTY and ICTR Statutes. It states that "a person who planned, instigated, ordered, committed or otherwise aided and abetted in the planning, preparation or execution of a crime referred to in Articles 2 of 4 of the present Statute shall be individually responsible for the crime. ${ }^{\prime 347}$ The Statute of the Special Court was drafted in 2000, one year after the initial Tadic decision embracing the concept of joint criminal enterprise ${ }^{348}$ The Statute of the Special Court, unlike the ICC Statute, however, contains no reference to joint criminal enterprise or common plan liability.

Nevertheless, the Special Court's indictments do specifically accuse individuals of participating in a joint criminal enterprise. The indictment of Charles Taylor, for example, accuses him of participating in a "common plan, purpose or design (joint criminal enterprise) which was to take any actions necessary to gain and exercise political power and control over the territory of Sierra Leone, in particular the diamond mining areas." ${ }^{349}$ At least ten other indictments from the Special Court for Sierra Leone also accuse the indictees of participating in a JCE to exercise control over Sierra Lcone ${ }^{350}$ Even in cases in which this particular JCE is not alleged, the prosecutor for the Special Court has issued indictments charging the defendant under a variety of forms of individual criminal responsibility,

International Convention for the Suppression of Terrorist Bombings, U.N. GAOR, 52d Sess., at art. 2, U.N. Doc. A/RES/52/164 (1997) (emphasis added).

347. United Nations, Statute of the Special Court for Sierra Leone, supra note 3, at art. 6.

348. See U.N. Security Council, Report of the Secretary General on the Establishment of a Special Court for Sierra Leone, U.N. Doc. S/2000/915 (2000).

349. Prosecutor v. Taylor, SCSL Indictment, Special Court for Sierra Leone, at paras. 23-25, Case No. SCSL-2003-01 (Mar. 7, 2003).

350. Prosecutor v. Kanu, SCSL Indictment, Special Court for Sierra Leone, at para. 23, Case No. SCSL-2003-13-I (Sept. 15, 2003); Prosecutor v. Kondewa, SCSL Indictment, Special Court for Sierra Leone, at para. 14, Case No. SCSL-2003-12-I (June 24, 2003) (referring to the accused's plan, purpose, or design); Prosecutor v. Fofana, SCSL Indictment, Special Court for Sierra Leone, at para. 14, Case No. SCSL-2003-I1-I (June 24, 2003) (same); Prosccutor v. Kamara, SCSL Indictment, Special Court for Sierra Lcone, at para. 23, Case No. SCSL-2003-10-1 (May 26, 2003); Prosecutor v. Gbao, SCSL Indictment, Special Court for Sierra Leone, at para. 25, Case No. SCSL-2003-09-1-009 (Apr. 16, 2003); Prosecutor v. Brima, SCSL Indictment, Special Court for Sierra Leone, at para. 23, Case No. SCSL2003-06-I (Mar. 7, 2003); Prosecutor v. Sesay, SCSL Indictment, Special Court for Sierra Leone, at para. 23, Case No. SCSL-2003-05-1 (Mar. 7, 2003); Prosecutor v. Bockarie, SCSL Indictment, Special Court for Sierra Leone, at para. 25, Case No. SCSL-2003-04-1 (Mar. 7, 2003); Prosecutor v. Koroma, SCSL Indictment, Special Court for Sierra Leone, at para. 24, Case No. SCSL-2003-03-1 (Mar. 7, 2003). 
including common purpose liability. Significantly, the language of these indictments includes a Category Three theory of JCE, that is, it charges the defendant with liability for all crimes reasonably foreseeable from the JCE. The indictment of Sam Hinga Norman, for example, charges him with various crimes that he "planned, instigated ordered, committed, or in whose planning, preparation or execution [he] otherwise aided and abetted, or which crimes were within a common purpose, plan or design in which [he] participated or were a reasonably foreseeable consequence of the common purpose, plan or design in which [he] participated." ${ }^{351}$ This language demonstrates that the prosecutor in Sierra Leone is aware of and embraces the most expansive application of the JCE, as it has been developed by the ICTY.

In East Timor (now Timor Leste), the Special Panel for Serious Crimes established by the United Nations Transitional Administration in East Timor (UNTAET) replicates the individual criminal responsibility provision of the ICC Statute, including its common purpose language. ${ }^{352}$ One of the indictments issued by the Prosecutor for Serious Crimes charges a variety of senior individuals, including Abilo Jose Osorio Soares, the former Governor of East Timor, with crimes against humanity. ${ }^{353}$ While the indictment merely reproduces the language of the individual criminal responsibility provision and therefore does not indicate whether Soares is charged with committing, ordering, aiding and abetting, or acting with a common purpose, the common purpose language is included in the indictment. ${ }^{354}$ Other indictments before the Special Panel also include this language. ${ }^{355}$

Most of the indictments we have located from the newest generation of international criminal courts, namely those in Timor Leste and Sierra Leone, rely (at least in part) expressly or implicitly on the theory of JCE liability. These developments provide evidence that the concept of JCE will continue to play an important role in international criminal law and heighten the stakes of the ICTY's jurisprudence in this area.

\section{Command Responsibility: The Example of Abu Ghraib}

The Abu Ghraib prison scandal provides a vivid example of the possible application of command responsibility principles. In April 2004,

351. Prosecutor v. Norman, SCSL Indictment, Special Court for Sierra Leone, at para. 13, Case No. SCSL-2003-08-I (Mar. 7, 2003).

352. U.N. Transitional Administration in East Timor, supra note 3, at $\S 14.3(\mathrm{~d})$.

353. Deputy General Prosceutor for Serious Crimes v. Wiranto, Indictment, Special Panel for Serious Crimes, at 36 Count 1, Case No. 5/2003 (Feb. 22, 2003).

354. Id. at 34-35.

355. See, e.g., General Prosecutor of the United Nations Transitional Administration in East Timor v. Sarmento, Indictment, at para. 11, Case No. 18/18A/I8B/18C/2001 (Aug. 7, 2001), available at http://www.jsmp.minihub.org/courtmonitoring/spsccaseinformation2000.htm. 
photographs beamed around the world revealed that U.S. soldiers guarding Iraqi detainees at the Abu Ghraib prison complex near Baghdad had subjected some detainees to degrading treatment. ${ }^{356}$ Most legal experts agree that the conduct depicted in the photographs amounts to violations of international criminal law. ${ }^{357}$ Other reports suggest that even more serious abuse, beyond that depicted in the infamous photographs, may have occurred. 358

While much of the resulting furor has focused on whether senior officials ordered the low-level soldiers appearing in the photographs to engage in such abuse, criminal liability on the part of senior officers can attach even in the absence of a direct command. As the discussion of command responsibility in Part III of this Article indicates, under international law ${ }^{359}$ a commander may be found criminally responsible for the misconduct of his subordinates if the commander had "effective control" over the subordinates, if the commander knew or had reason to know of his subordinates' crimes, and if the commander failed to prevent or punish the offenses. ${ }^{360}$ Furthermore, the superior can be a civilian, as long as the requisite degree of effective control exists.

Assuming that senior U.S. officials did not order the conduct at issue, ${ }^{361}$ have President George Bush, Secretary of Defense Donald

356. See, e.g., Leila Nadya Sadat, Accused Fall Under U.S. and International Laws, ST. LouIs PosT-DisPatCH, May 23, 2004, at B5; Julian Borger, U.S. Military in Torture Scandal: Use of Private Contractors in Iraqi Jail Interrogations Highlighted by Inquiry into Abuse of Prisoners, THE Guardian, Apr. 30, 2004, Guardian Home Pages at 1. The abuse that occurred at Abu Ghraib is detailed in several reports issued or commissioned by the U.S. Government. See, e.g., MG George R. Fay, AR 15-6 Investigation of the Abu Ghraib Prison and 205th Military 1ntelligence Brigade 68-95 (Aug. 23, 2004), available at http://www.c-span.org/pdf/armyabughraib.pdf (documenting forty-four instances of "abuse," including "physical and sexual abuse; improper use of military working dogs; humiliating and degrading treatments; and improper use of isolation") [hereinafter Fay Report]; James R. Schlesinger et al., The lndependent Panel to Review DOD Detention Operations 12-13 (Aug. 24, 2004), available at $\mathrm{http} / / / \mathrm{www} . d e f e n s e l i n k . m i l / n e w s / A u g 2004 / \mathrm{d} 20040824$ finalreport.pdf (describing abuses) [hereinafter Schlesinger Report].

357. See Leila Nadya Sadat, Accused Fall Under U.S. and International Laws, ST. LouIS PostDisPaTCH, May 23, 2004, at B5.

358. Richard Serrano \& Greg Miller, The Conflict in Iraq; Documents Provide New Details of Abuse, L.A. TIMEs, May 23, 2004, at A1 (describing alleged homicides of two prisoners); Schlesinger Report, supra note 356, at 13 (stating "[t]here were five cases of detainee deaths as a result of abuse by U.S. personnel during interrogations [in Afghanistan and 1raq]" and noting that twenty cases of detainee deaths in lraq are "still under investigation").

359. Command responsibility principles also apply as a matter of U.S. law. Army Field Manual 27-10 provides that "The commander is ... responsible if he has actual knowledge, or should have knowledge, through reports received by him or through othcr means, that troops or other persons subject to his control are about to commit or have committed a war crime and he fails to take the necessary and reasonable steps to insure compliance with the law of war or to punish violators thereof." Department of the Army, Army Field Manual No. 27- Io, § 501 (1956).

360. See, supra text accompanying note 209 (laying out three-part test for command responsibility liability).

361. The revelation of memoranda authored by senior U.S. officials that appear to condone the use of severe interrogation techniques suggests that mistreatment of detainees may have formed part of 
Rumsfeld, or any of the military or civilian officers that lie upon the chain of command incurred criminal liability for their failure to prevent or punish the abuses at Abu Ghraib? ${ }^{362}$ The answer to this question depends on the mental state applicable to command responsibility and which of these individuals had "effective control" over the guards and intelligence officers at the prison.

Taking the latter question first, reports about Abu Ghraib in the relevant period indicate both confusion over whether the military police or the military intelligence units were in charge of those conducting the interrogations, ${ }^{363}$ and the possible involvement of civilian intelligence agencies and contractors. ${ }^{364}$ Who, precisely, had effective control over the prison has yet to be worked out. The legal standard applicable to effective control will be critical to making this determination, and turns on whether the accused had the material ability to prevent and punish offenses. ${ }^{365}$ Given that the U.S. Army is normally a well-functioning hierarchy, with clear lines of formal authority (as opposed to the sort of ad hoc militias found in many conflicts), senior officers will be likely to have had effective control in a legal sense over soldiers under their de jure command and would not be able to claim that they lacked effective control in the field. The 1CTY Appeals Chamber has held that de jure control of this sort may result in a prima facie presumption of "effective control" absent some proof that the individual lacked a material ability to prevent and punish offenses. ${ }^{366}$

The mens rea of command liability is equally important to the resolution of criminal responsibility. If command liability is a strict liability offense, any superior with effective control is responsible for all the criminal activity that went unpunished at Abu Ghraib. If command responsibility

official U.S. policy. See Passing the Buck, ST. Louis Post-Dispatch, Aug. 8, 2004, at B2. At the very least, "the existence of confusing and inconsistent interrogation technique policies contributed to the belief that additional interrogation techniques were condoned in order to gain intelligence." LTG. Anthony R. Jones, AR 15-6 Investigation of the Abu Ghraib Prison and 205th Military Intelligence Brigade 15 (Aug. 23, 2004), available at http://www.c-span.org/pdf/armyabughraib.pdf [hereinafter Jones Reportl.

362. The Schlesinger Report "finds that commanding officers and their staffs at various levels failed in their duties and that such failures contributed directly or indirectly to detainee abuse" at Abu Ghraib. Schlesinger Report, supra note 356, at 43.

363. Schlesinger Report, supra notc 356, at 17,43-45 (describing the "series of tangled command relationships" at Abu Ghraib); Tara Lee, Commentary: Tangled Thread of Military Responsibility, L.A. Times, Aug. 5, 2004, at B15; David Zucchino \& Greg Miller, Officer Was at Crossroads of Abu Ghraib Command, L.A. Times, Aug. 1, 2004, at A20 (quoting Lt. Gen. Ricardo Sanchez, the top U.S. commander in lraq, describing command at Abu Ghraib as "dysfunctional").

364. Ariana Eunjung Cha \& Renae Merle, Line Increasingly Blurred Between Soldiers and Civilian Contractors, WASH. Post, May 13, 2004, at Al. The Schlesinger Report notes that "[c]ontractors were a particular problem at Abu Ghraib." Schlesinger Report, supra note 356, at 69. The Fay Report states that "ClA dctention and interrogation practices led to a loss of accountability, abuse, reduced interagency cooperation, and an unhealthy mystique that further poisoned the atmosphere at Abu Ghraib." Fay Report, supra note 356, at 52-53.

365. Celebići Appeals Judgement, supra note 16, at para. 197.

366. Id. 
requires negligence or recklessness, then the question of liability centers on when the first reports to document the abuses, such as those authored by the International Committee for the Red Cross, ${ }^{367}$ were provided to the U.S. government and when the first steps to punish those immediately responsible were taken. ${ }^{368}$ Whatever the answers to these questions, the facts of Abu Ghraib should make clear the importance both of determining the precise mental state applicable to command responsibility and the application of the "effective control" standards to wartime conditions.

In fact, a group of five Iraqi citizens has filed a criminal complaint in Germany against U.S. Defense Secretary Rumsfeld and other U.S. officials alleging criminal liability for the offenses at Abu Ghraib on a command responsibility theory. ${ }^{369}$ Whatever the fate of the suit, Abu Ghraib demonstrates the relevance of command responsibility as a theory of liability. ${ }^{370}$ In situations where criminal liability arises from a political leader's failure to prevent or punish violations of international law rather than from any sort of intentional plan, JCE cannot be used. Command responsibility, therefore, is likely to remain a key weapon in international law.

\section{B. Domestic Prosecution of International Terrorists}

The importance of criminal law, human rights, and transitional justice influences in international criminal law should make domestic jurisdictions sensitive to the implications of adopting international criminal law doctrines wholesale in their domestic criminal law systems. Such borrowing will be necessary in nations that have ratified the ICC Statute. The ICC Statute gives jurisdictional priority to national prosecutions, if those nations are able and willing to prosecute the crimes that have occurred.$^{371}$ In order to take jurisdiction, however, states must incorporate genocide, crimes against humanity, and war crimes into their domestic codes ${ }^{372}$ Even states that have not ratified the ICC Statute may adopt crimes derived from international law into their penal codes. The Iraqi Special Tribunal for Crimes Against Humanity devised to try Saddam Hussein and others, for

367. Josh White \& Scott Higham, Army Calls Abuses 'Aberrations,' WasH. Post, July 23, 2004, at Al (describing Red Cross Reports).

368. The Jones Report, for example, discusses "indications and warnings" that "additional oversight and corrective action were needed" at Abu Ghraib. These alerts included the ICRC reports, althougb the Jones Report does not detail fully the dates of these or of the other "indications and warnings." Jones Report, supra note 361 , at 11.

369. Deutsche Welle, Rumsfeld Sued for Alleged War Crimes, at http:/www.truthout.org/ docs_04/120104X.shtml.

370. Although the United States is not a party to the $1 \mathrm{CC}$, some of its coalition partners, including the United Kingdom, are, and citizens of those nations could theoretically be prosecuted by the lCC for crimes in lraq. See ICC STATUTE, supra note 9, at art. 12; Severin Carrell, Blair Faces New War Crimes' Accusation, INDEP. ON SUNDAY, Jan. 18, 2004, at 6.

37I. ICC STATUTE, supra note 9, at art. 17.

372. Katherine L. Doherty \& Timothy L.H. McCormack, 'Complementarity' as a Catalyst for Comprehensive Domestic Penal Legislation, 5 U.C. Davis J. INT'L L. PoL'y I47, 174-75 (1999). 
example, includes the international crimes of genocide, crimes against humanity, and war crimes in its jurisdiction. ${ }^{373}$ Domestic incorporation of international crimes by individual states is both inevitable and critical to the effective enforcement of international criminal law.

It is a different matter, however, for nations to assimilate wholesale the liability theories that international criminal law has devised and apply them in other contexts. We view with particular concern the United States's apparent incorporation of JCE into its recent regulations for military commissions, which define the crime of conspiracy in part as follows:

The accused entered into an agreement with one or more persons to commit one or more substantive offenses triable by military commission or otherwise joined an enterprise of persons who shared a common criminal purpose that involved, at least in part, the commission or intended commission of one or more substantive offenses triable by military commission. ${ }^{374}$

Although the regulations do not identify the origins of the "common criminal purpose" language, there are good reasons to believe that such language is, in fact, drawn from the JCE doctrine of international criminal law. First, this language closely tracks some of the formulations of JCE given by international criminal tribunals, and there is no other apparcnt sourcc for the language, since that terminology is not used in either the Uniform Code of Military Justice ${ }^{375}$ or in the civilian criminal provisions of the U.S. Code. ${ }^{376}$ Second, elsewhere in the definitions of crimes, the military commission regulations employ language and terminology from the

373. Iraqi Special Tribunal for Crimes Against Humanity, The Statute of the Iraqi Special Tribunal, at http://www.cpa-iraq.org/human_rights/Statute.htm (last visited Oct. 3, 2004).

374. 32 C.F.R. $\$ 11.6(\mathrm{c})(6)(\mathrm{i})(\mathrm{A})$ (2003) (emphasis added). The regulations also require that " $[\mathrm{t}] \mathrm{he}$ accused knew the unlawful purpose of the agreement or the common criminal purpose of the enterprise and joined in it willfully, that is, with the intent to further the unlawful purpose; and lo]ne of the conspirators or enterprise members, during the existence of the agreement or enterprise, knowingly committed an overt aet in order to accomplish some objective or purpose of the agreement or enterprise." 32 C.F.R. § $11.6(\mathrm{c})(6)(\mathrm{i})(\mathrm{B})$-(C) (2003).

375. The Uniform Code of Military Justice provides in relevant part that any person "who conspires with any other person to commit an offense under this chapter shall, if one or more of the conspirators does an act to effect the object of the conspiracy, be punished as a court-martial may direct." 10 U.S.C. $\$ 881$ (2000).

376. The language used in the regulation and the use of the concept of an enterprise is much more similar to the joint criminal enterprise as uscd in international criminal law than to the use of "enterprise" in RICO or the continuing criminal enterprise statute. Compare 18 U.S.C. § 1952(c) (2004) (RICO provision prohibiting "any person employed by or associated with any enterprise engaged in, or the activities of which affect, interstate or foreign commerce, to conduct or participate, directly or indirectly, in the conduct of such enterprise's affairs through a pattern of racketeering activity or collection of unlawful debt.") with 21 U.S.C. $\$ 848(\mathrm{c})(2000)$ (defining "continuing criminal enterprise" to include certain violations that are "part of a continuing series of violations of this subchapter or subchapter 11 of this chapter ... which are undertaken ... in concert with five or more other persons with respect to whom such person occupies a position of organizer, a supervisory position, or any other position of management [and] from which such person obtains substantial income or resources"). 
ICC Statute, the ICC Elements of Crimes, and earlier U.S. diplomatic proposals for the ICC Elements of Crimes. ${ }^{377}$ The regulations, for example, include provisions on command responsibility that track international criminal law. ${ }^{378}$ In addition, the regulations state that "[ $\left.t\right]$ hese crimes and elements derive from the law of armed conflict," "379 a synonym for international humanitarian law, and thus the military commissions purport to be applying, at least in part, the same body of law applied by international criminal courts. Finally, in recent litigation over the military commission's inclusion of conspiracy as a crime within their jurisdiction, the U.S. government has relied heavily on the JCE jurisprudence from the ICTY to argue for the existence of conspiracy as a crime in international law. ${ }^{380}$

There are some differences between the usage in the military commission regulations and in international criminal law. Most notably, the military commission regulations include the language in the context of defining conspiracy, a separate crime in and of itself, although the definition provided in the regulations also apparently refers to conspiracy in the

377. See National Institute of Military Justice, Military Commission Instructions SOURCEBOOK 99-101 (2003) (comparing provisions of military commission regulations and ICC definitions). The ElEmENTS OF CRIMEs of the International Criminal Court defines elements of the war crime of attacking civilians, as follows:

1. The perpetrator directed an attack. 2. The object of the attack was civilian objects, that is, objects which are not military objective. 3 . The perpetrator intended such civilian objects to be the object of the attack. 4. The conduct took place in the context of and was associated with an international armed conflict. 5. The perpetrator was aware of factual circumstances that established the existence of an armed conflict.

Assembly of States Parties to the Rome Statute of the International Criminal Court, Elements of Crimes of the International Criminal Court, at art. 8(2)(b)(ii), U.N. Doc. PCNICC/2000/1/Add. 2 (2000).

Compare with 32 C.F.R. $\S 11.6(\mathrm{a})(2)(\mathrm{i})$, which defines elements of crime of

Attacking civilians" to include "(A) The accused engaged in an attack; (B) The object of the attack was a civilian population as such or individual civilians not taking direct or active part in hostilities; (C) The accused intended the civilian population as such or individual civilians not taking direct or active part in hostilities to be an object of the attack; and (D) The attack took place in the context of and was associated with armcd conflict.

32 C.F.R. $\S 11.6(\mathrm{a})(2)(\mathrm{i})(2003)$

378. 32 C.F.R. $\$ 11.6(c)(3)$,(4) (2003). Command responsibility is broken into two types, perpetrating and misprision, with the distinction being that a commander "charged with failing adequately to prevent or repress a substantive offense ... should be charged for the related substantive offense as a principal" while a commander "charged with failing to takc appropriate punitive or investigative action subsequent to the perpetration of a substantive offense triable by military commission should not be charged for the substantive offense as a principal" but should instead "be charged for the separate offense of failing. to submit the matter for investigation and/or prosecution...." Id. at $\S \S 11.6(\mathrm{c})(3)(\mathrm{ii})(\mathrm{B}),(\mathrm{c})(4)(\mathrm{ii})(\mathrm{B})$. By contrast, international criminal law does not differentiate in terms of liability between command responsibility for failure to prevent and failure to punish. And, unlike the ICC statutc, the military commission regulations do not diffcrentiate between the mental state of civilian and military superiors. See id. at $\$ 11.6(\mathrm{c})(6)(i)$.

379. 32 C.F.R. $\S 11.3$ (2003).

380. Prosecution Response at 16-18, United States v. Hamdan, at http://www.defenselink.mil news/Oct2004/d20041026laws.pdf. 
Pinkerton sense of a theory of liability. ${ }^{381}$ Nevertheless, based on the language of the two documents, it does not seem plausible that the drafters' use of the JCE terminology was unintentional or coincidental.

The first indictments issued in the U.S. military commissions suggest that JCE may play a prominent role in these prosecutions. The indictments against Ibrahim Ahmed Mahmoud al Qosi, Al Hamzi Ahmad Sulayman al Bahlul, David Hicks, and Salim Ahmed Hamdan each charge that the defendants "willfully and knowingly joined an enterprise of persons who shared a common criminal purpose and conspired and agreed" with various persons to commit a variety of offenses including attacking civilians and civilian objects, murder by an unprivileged belligerent, destruction of property by an unprivileged belligerent, and terrorism. ${ }^{382}$ The defendants are alleged to have played a variety of supporting roles in al Qaeda (one is alleged to have been an accountant for the organization, one is said to have made propaganda films, one apparently was a driver for Usama bin Laden and other high-ranking al Qaeda members, and one is an Australian who trained with al Qaeda and fought against the United States and Coalition forces in Afghanistan). ${ }^{383}$ The indictments describe a wide range of crimes committed by al Qaeda between 1989 and 2001, suggesting that each defendant might be held liable for all of those activities. ${ }^{384}$

In addition, several hints of possible uses of the doctrine emerge from the rest of the commission regulations and from the government's filings in some of the "enemy combatant" cases. These sources reflect the government's efforts to characterize terrorist groups as participants in an armed conflict and to attach legal significance to membership or other affiliation with such terrorist groups. For example, the military commission

381. Compare 32 C.F.R. § 11.6(c) (2003) ("[R]egardless of whether the substantive offense was completed, a person may be criminally liable of the separate offense of eonspiracy in addition to the substantive offense.") with id. at $\S 11.6(\mathrm{c})(6)(\mathrm{ii)}$ (E) ("Each conspirator is liable for all offenses committed pursuant to or in furtherance of the conspiracy by any of the co-conspirators, after such conspirator has joined the conspiracy and while the conspiracy continues and such conspirator remains a party to it.").

382. Charge: Conspiracy, at para. 12, United States v. Hamdan, (July 14, 2004), available at http: //www.defenselink.mil/news/Jul2004/d20040714hec.pdf; Charges: Conspiracy; Attempted Murder by an Unprivileged Belligerent; Aiding the Enemy, at para. 19, United States v. Hicks, (June 10, 2004), available at http://www.defenselink.mil/news/Jun2004/d20040610cs.pdf [hereinafter Hicks Indictment]; United States v. al Bablul, Charge: Conspiracy, at para. 14 (Feb. 24, 2004), available at http://www.defenselink.mil/news/Feb2004/d20040224AlBahlul.pdf [hereinafter al Bahlul Indictment]; United States v. al Qosi, Charge: Conspiracy, Military Commission, at para. 18 (Feb. 24, 2004), available at http://www.defenselink.mil/news/Feb2004/d20040224AlQosi.pdf [hereinafter al Qosi Indictment].

383. See Hamdan Indictment, supra note 382, at para. 13; Hicks Indictment, supra note 382 , at para. 20; al Bahlul Indictment, supra note 382, at para. 15(g); al Qosi Indictment, supra note 382, at para. 19(e).

384. See Hamdan Indictment, supra note 382, at paras. 3-11; Hieks Indictment, supra note 382, at paras. 10-18; al Bahlul Indictment, supra note 382, at paras. 3-13; al Qosi Indictment, supra note 382, at paras. 3-17. 
regulations define the term "enemy" to include "any organization of terrorists with international reach." 385 Similarly, in the case of Jose Padilla, the alleged "dirty bomber" arrested and detained by the United States as an "enemy combatant," the government contends that Padilla can be treated as an "enemy combatant" under the laws of war because he is "associated" with al Qaeda, the "organization" with which the United States is engaged in an armed conflict. ${ }^{386}$

The government thus argues that Padilla's association with al Qaeda brings him within the scope of the congressional resolution authorizing the use of force against the "nations, organizations, or persons" that "planned, authorized, committed, or aided the terrorist attacks that occurred on September 11, 2001,"387 although Padilla is not alleged to have played any role in the September 11 plot. In other words, like the military commission indictments, it suggests a theory wherein all those associated with al Qaeda are legally deemed associated with all of the group's crimes. Whether or not such a person could be found guilty on a JCE theory under international criminal law would depend on what kind of action, if any, international judges will require of each participant in the enterprise in furtherance of the common plan and how broadly judges allow the enterprise to be defined. One inference from these trends is that the government may eventually argue before the military commissions that an individual who "joins" an enterprise with a common criminal purpose, such as the terrorist organization al Qaeda, may be guilty of a war crime simply by having "joined" the organization or may even be vicariously liable for all crimes committed by the enterprise.

Such an approach raises the problem of guilt by association that shadows the outer reaches of JCE. It would also be vulnerable to some of the same criticisms as the attempts at Nuremberg to make membership in a criminal organization an offense in and of itself. ${ }^{388}$ To be sure, the tension with culpability norms of criminal law is significantly mitigated here by the requirement in the regulations that the defendant have intended to further the unlawful purpose of the group. ${ }^{389}$ However, if the extended form of

385. 32 C.F.R. $\S 11.5(\mathrm{~b})(2003)$.

386. See Brief for Petitioner, Rumsfeld v. Padilla, 124 S. Ct. 2711 (2004) (No. 03-1027). Professor Martinez was counsel for Padilla in the U.S. Supreme Court.

387. Padilla, 124 S. Ct. at 2715 n.1; Authorization for Use of Military Foree, Pub. L. No. 107-40, 115 Stat. 224 (2001).

388. During the Cold War, the U.S. Supreme Court imposed limits on laws criminalizing membership in the communist party and suggested that the Constitution required that individuals have some intent to further the illegal aims of the party before they could be punished. See, e.g., Scales v. United States, 367 U.S. 203, 228 (1961); Aptheker v. Secretary of State, 378 U.S. 500, 514 (1964); Elfbrandt v. Russell, 384 U.S. 11, 17 (1966).

389. Other recent laws aimed at punishing those who give "material support" to terrorist organizations go further in attenuating or eliminating intent requirements. See DAvID COLE \& JAMES X. Dempsey, Terrorism and the Constitution: Sacrificing Civil Liberties in the Name of NATIONAL SECURITY 118-22 (2002) (describing broad scope of provisions of AEDPA and PATRIOT 
JCE liability is extended to the military commissions, the purpose of al Qaeda may be defined very broadly, and each individual member may be held responsible for the full range of crimes committed by anyone in the group, all of which may be deemed foreseeable in some broad sense. One doubts whether prosecutorial discretion will prevent U.S. prosecutors from using the full power of JCE in cases involving crimes, like terrorism, that elicit such profound political and security concerns.

In at least two other cases, the U.S. government has argued that a person may be convicted for providing material support or resources to an organization designated as a "foreign terrorist organization" by the U.S. government, and therefore be sentenced to life imprisonment, even if that person had no idea of the government's designation or of the organization's illegal activities. ${ }^{390}$ In one of the cases, a three-judge panel of the Ninth Circuit Court of Appeals rejected the government's construction of the statute as requiring no scienter requirement because of concerns that such a reading would "contravene[] the Fifth Amendment's requirement of 'personal guilt." ${ }^{\prime 391}$ In United States v. Hammoud, the Fourth Circuit, sitting en banc, affirmed a trial court decision that did not require the U.S. government to prove at trial that a person charged with providing material support or resources to an organization designated as a "foreign terrorist organization" specifically intended that his support further the organization's illegal activities. ${ }^{392}$ In that case, the dissenting judge argued that the "'material support' provisions constitute a violation of the Fifth Amendment when applied without the necessary specific intent requirement," as " "personal guilt' . . is the hallmark of our criminal justice system. ${ }^{.393}$ These decisions raise concerns similar to those we have articulated regarding the use of the most expansive forms of JCE. The government has been using the material support statute at an increasing pace, from nine cases in 2002 to thirty-four cases in 2003.394

Because JCE doctrine has even fewer limits than already expansive domestic conspiracy law, ${ }^{395}$ it offers the prosecutor the potential to expand

Act making it a crime to provide material support to a designated terrorist organization and suggesting that mere membership may in some instances give rise to liability).

390. Humanitarian Law Project v. U.S. Dep't of Justice, 352 F.3d 382 (9th Cir. 2003). The decision has since been vacated for en banc review. 382 F.3d 1154 (9th Cir. 2004). The en banc decision bad not been handed down when this Article went to press. See also Humanitarian Law Project v. Ashcroft, 2004 U.S. Dist. LEXIS 926 (C.D. Cal. 2004).

391. Humanitarian Law Project, 352 F.3d at 397.

392. 381 F.3d 316, 325 (4th Cir. 2004) (en banc).

393. Id. at 380,385 (Gregory, J., dissenting).

394. See Pam Louwagie, Warsame Case Has Familiar Ring; New York Defendants Pleaded Guilty to Similar Charges of Aiding Al-Qaida, MINN. STAR TRIB., Feb. 9, 2004, at IB (describing usc of statute as a tool to elicit plea bargains and noting that "[d]efense attorneys raised questions about the government's definition of 'material support,' though specifically, whether simply attending a training camp constitutes material support.").

395. See discussion supra text accompanying notes 306-09. 
the range of crimes for which an individual may be held responsible. As discussed in Part IV, the ICTY has not recognized any structural limitations on the enterprises alleged, and it is therefore unnecessary to delineate clearly under international law the structure of the organization in a way that might be required under domestic conspiracy law. ${ }^{396}$ This difference may provide a significant advantage in targeting the members of terrorist organizations like al Qaeda, which involve multiple cells of individuals who may or may not know about the activities of other cells. ${ }^{397}$ Indeed, the enterprise might not be limited to al Qaeda but might also encompass other terrorist organizations that have loose ties to one another ${ }^{398}$ Consequently, it may be possible to characterize al Qaeda's activities as one giant criminal enterprise in which each participant may be liable for all the foreseeable crimes of other participants.

In our view, the importation of the international criminal law doctrine of JCE for use in domestic terrorist prosecutions raises serious questions. International terrorism is a problem of utmost importance, and we in no way wish to minimize the criminality of its perpetrators or thc suffering of its victims. Although some have suggested that large-scale international terrorist attacks like those on the World Trade Center may constitute war crimes and crimes against humanity, ${ }^{399}$ we believe international terrorism presents a separate and distinct problem from the kinds of human rights abuses that have been the bread and butter of international criminal prosecutions at the ICTY. The differences between the types of crimes are reflected in the decision of the drafters of the ICC Statute not to give that court jurisdiction over international terrorism. ${ }^{400}$

The potential application of the more expansive forms of JCE to domestic criminal prosecutions of terrorists demonstrates the danger of such an unbounded doctrine. While we are sympathetic to the desire to maximize accountability for human rights violations, we are also concerned that the broadest form of the doctrine is unnecessary to achieve that goal, particularly in light of the availability of command responsibility. Our concerns about JCE only heighten once that doctrine is cut loose from

396. See generally KADISH \& SCHULHOLFER, supra note 174, at 714-23 (describing restrictions on the scope of the agrecment in U.S. conspiracy law).

397. See, e.g., Phil Hirshkorn et al., Blowback, 13 JANE's Intelligence Rev. (Aug. 1, 2001), at http://www.mwarrior.com/alqaeda.htm.

398. See, e.g., Raymond Bonner \& Don Van Natta, Jr., Regional Terrorist Groups Pose Threat, Experts Warn, N.Y. TimEs, Feb. 8, 2004, at 1 (describing how "militant groups, with roots from Southeast Asia, Central Asia and the Caucasus to North Africa and Europe, are believed to be loosely affiliated with Al Qaeda"); David E. Kaplan et al., The Shadow Over The Summit, U.S. News \& WORLD REP., Oct. 20, 2003, at 29 (describing links between al Qaeda and "Jemaah Islamiyah, an ambitious homegrown network with cells that stretch from Thailand and Indonesia down to Australia").

399. See, e.g., Derek Jinks, September 11 and the Laws of War, 28 YALE J. INT'L L. 1, 2-3 (2003).

400. See Herman von Hebel \& Darryl Robinson, Crimes Within the Jurisdiction of the Court, in The International Criminal Court: The Making of the Rome Statute: Issues, Negotiations, RESUlTS 79, 86 (Roy S. Lee ed., 1999). 
the human rights framework in which it originated, and it is applied to what have conventionally been viewed as domestic or transnational crimes. At the very least, the potential application of JCE to crimes like terrorism should inform the deliberations of international judges and prosecutors in their decisions of how aggressively to press, and how broadly to interpret, this powerful theory of liability.

\section{Conclusion}

Over the past ten years, international criminal law has emerged from its erstwhile status as an obscure branch of international law into an important body of law and procedure uniquely suited to providing accountability for episodes of mass atrocity and to coping with difficult political transitions. The judges, prosecutors, defense counsel, diplomats, and scholars who have accomplished this transformation deserve much credit for the thoughtful and diligent way they have approached their daunting task. The revitalization of international criminal law has occurred against the backdrop of humanitarian tragedy, political pressure, and financial strain. When thousands and even hundreds of thousands of people have been killed, raped, and tortured, providing legal space for the operation of the culpability principle and other limitations on prosecution and punishment may seem like unaffordable luxuries. Particularly given the time pressures under which the ICTY and ICTR are currently operating, a call to rein in the liability principles that have been most useful to securing convictions of perpetrators of heinous crimes strikes a discordant note.

Nevertheless, those who seek to perpetuate international criminal law must take a long-term view of the body of law with which they have been entrusted. The viability of international criminal law depends on its sensitive and careful use by those with the power to determine its contours. As long as international criminal law lays claim to being a system of criminal law, with the power to deprive defendants of their liberty for significant periods of time, it must also protect the philosophical commitments that morally justify exacting this heavy price. The culpability principle represents one of the most important of these commitments-one that is easily sacrificed both for good motives and for bad.

In this Article, we have advocated that judges and prosecutors be more sensitive to the dictates of the culpability principle in their development of JCE. We have argued against the most far-reaching applications of the doctrine out of a concern that low-level perpetrators may be charged with and convicted of large-scale crimes, even though they may have played only a minor role in the mass atrocity that unfolded, or that highlevel leaders may be convicted of crimes for which their responsibility appears tenuous. While we believe that even the most sprawling form of JCE may be appropriate in some cases involving the most senior 
leadership, we do not believe that high rank alone should guarantee conviction as a principal perpetrator for all ensuing crimes.

Our case for a more careful use of JCE as well as a reinvigoration of command responsibility rests not just on the culpability principle, but also upon the importance of transitional justice and human rights analysis to international criminal law. In particular, the truth-telling aspect of transitional justice adds special urgency to the production of an accurate and nuanced historical record from international prosecutions. While criminal trials cannot substitute for historical inquiry, high-profile international trials have shaped historical inquiry and collective memory - both for good and for ill. The Nuremberg proceedings, for example, have been criticized for dwelling too much on the aggressive war charges and underemphasizing the persecution of the Jews. ${ }^{401}$ Liability theories that distort the contribution of individual defendants to the crimes that ultimately occurred run the risk, over time, of producing a record of a violent period that fails to capture how and why the crimes occurred. The dangers posed by such a failing are not merely academic, as the intense interest within the former Yugoslavia in the trial of Slobodan Milošević illustrates. The effectiveness of trials to the process of national reconciliation depends, to some extent, on the perceived accuracy and fairness of the trials.

We have also observed the extent to which the orientation and interpretive methods of human rights law have shaped the development of international criminal law. We argue that the human rights elements of international criminal law should not automatically trump key principles from the criminal law and transitional justice traditions. Nevertheless, we view all three traditions as central to the aims of international criminal law; indeed we believe that faithful adherence to criminal culpability principles is the surest path to actually achieving the human rights and transitional justice aims of international criminal law.

We recognize that the three key influences we have identified-the criminal law, human rights, and transitional justice paradigms-stand in some tension with each other. A rigorous interpretation of the culpability principle, for example, may frustrate the search for greater criminal accountability. Similarly, a strong emphasis on the historical narrative aspects of international trials runs the risk of ignoring the culpability of the individual actually on trial. Indeed, it is the tensions among these three forces that have shaped and continue to provoke some of the most difficult questions in international criminal jurisprudence. While there is no automatic resolution to the question of how to privilege these concerns, we hope that international judges and prosecutors remain sensitive to how their decisions may affect the delicate balance among them.

401. BLoXHAM, supra note 153 , at 2 . 
We believe that the tripartite framework we propose in this Article may help them achieve this balance by making explicit the competing forces at work in international criminal law and the trade-offs they entail. For example, there may be some areas in which the criminal law tradition has been too dominant at the expense of the human rights and transitional justice models. The treatment of victims of mass atrocity may provide such an example, insofar as there are inadequacies in witness protection and support programs and plans for reparations. Similarly, transitional justice goals of international criminal law cannot be achieved solely through a narrow focus on the trials themselves, but instead must be achieved through effective outreach and communication with affected communities about the course and outcomes of the criminal process.

We also urge international judges to be cognizant of the effects of some of their more sweeping interpretations of international law on the reception and use of that law in domestic fora. In addition, we advise domestic legislators and judges to approach the transplantation of international criminal jurisprudence with some caution. The cases adjudicated in international criminal fora differ materially in complexity and in scope from most national criminal prosecutions. In international cases, proof is typically harder to secure, the number of victims dwarfs that of most domestic crimes, the crimes are more complex, the trials are substantially longer, and the political implications of the proceedings are more acute. While many of the principles developed by judges at the ICTY, ICTR, and ICC will no doubt be important and useful for municipal criminal systems, domestic lawmakers and law-interpreters may wish to resolve some of the difficult questions faced in international criminal law in the last ten years with different solutions. The expansive liability theory of JCE, for example, may not be as necessary in the kinds of criminal prosecutions typically adjudicated at the national level and may represent an unacceptable erosion of the culpability principle.

Today, international criminal law is routinely offered as an important solution to vexing international problems. Former members of the Khmer Rouge, ${ }^{402}$ Saddam Hussein ${ }^{403}$ and Hissene Habre ${ }^{404}$ may all face trials under international law for crimes committed against their citizens. International criminal law has matured in the last ten years to the state

402. Seth Mydans, A Top Khmer Rouge Leader, Going Public, Pleads Ignorance, N.Y. TIMEs, Jan. 3, 2004, at A4.

403. Peter Slevin, Iraqi Governing Council Says It Wants to Try Hussein, WaSH. Post, Dec. 15, 2003, at A9. Due to the length of the discovery process, U.S. officials say that Hussein's trial may be delayed for over a year. Scheherezade Faramarzi, Violence Delays Saddam Trial Date, THE AdVERTISER, Oct. 5, 2004, Foreign at 35.

404. Anne Penketh, Face to Face with Those He Tormented: War Crimes Trial for Tyrant of Chad Tyrant Goes in the Dock, INDEPENDENT, Oct. 17, 2003, at 16. 
where it is ready to address the challenges of these difficult prosecutions. Its viability, however, rests on careful and sensitive decisions by judges and prosecutors in the cases currently underway in the Hague, in Arusha, in Freetown, and in Timor Leste. In this Article, we have sought to provide a framework that might assist those who develop this body of law in understanding its central challenges and resolving its most vexing questions in a way that preserves its complex heritage and fulfills its laudable purposes. 
